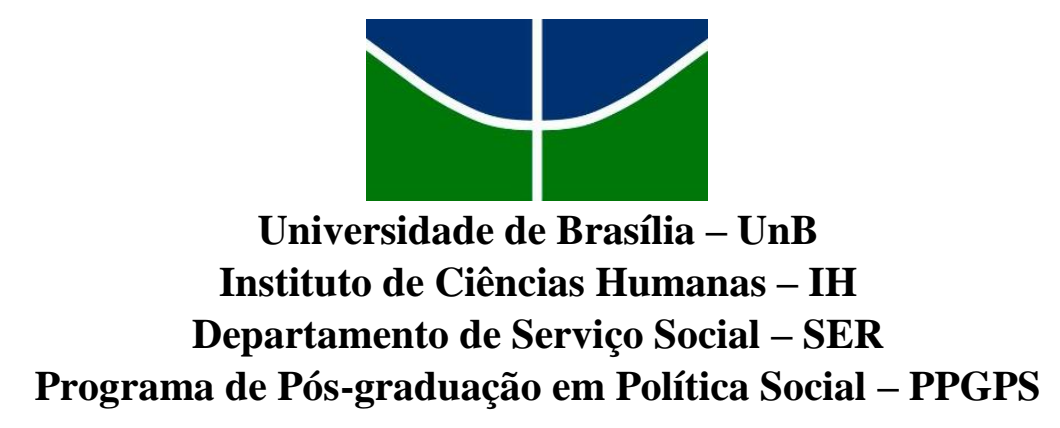

Viviane Moraes Dias

\title{
"NEODESENVOLVIMENTISMO" E POLÍTICA SOCIASSISTENCIAL EM TEMPO DE CRISE SISTÊMICA DO CAPITAL
}

Brasília, outubro de 2015. 
Viviane Moraes Dias

\section{"NEODESENVOLVIMENTISMO" E POLÍTICA SOCIASSISTENCIAL EM TEMPO DE CRISE SISTÊMICA DO CAPITAL}

Dissertação apresentada ao Programa de Pós-graduação em Política Social da Universidade de Brasília como requisito parcial para obtenção do grau de mestre em política social.

Orientadora: Prof. ${ }^{a}$ Dr. Potyara A. P. Pereira.

Brasília, outubro de 2015. 
BANCA EXAMINADORA

\author{
Prof ${ }^{\text {a }}$ Dra . Potyara Amazoneida P. Pereira \\ Orientadora \\ PPGPS/SER/UnB
}
Prof $^{\mathbf{0}}$ Dr. Perci Coelho de Sousa
Membro Interno
PPGPS/SER/UnB

\author{
Dr. Joselito Pacheco \\ Membro Externo \\ Secretaria da Fazenda do Distrito Federal
}

Prof ${ }^{a}$ Dr. Newton Narciso Gomes Jr.

Membro Suplente

PPGPS/SER/UnB

Brasília, outubro de 2015. 


\section{AGRADECIMENTOS}

Primeiramente, gostaria de agradecer profundamente a minha orientadora Prof ${ }^{\mathrm{a}}$ $\operatorname{Dr}^{\mathrm{a}}$ Potyara Amazoneida Pereira Pereira, pelo privilégio de mais uma vez ser sua orientanda. Merecedora de toda a admiração e respeito, um exemplo não só de professora, mas também de pesquisadora e pessoa, presença humana totalmente condizente com sua filiação teórica e política. Sou muito grata por seus ensinamentos, atenção dispensada, paciência com minhas diversas falhas e por não ter desistido de caminhar comigo nessa jornada, mesmo diante dos desafios colocados no percurso. Mais uma vez, muito obrigada! Sem a esta professora, esta dissertação que ora se apresenta, sequer chegaria a ser colocada sob avaliação.

Agradeço ao Dr. Joselito Pacheco, aos professores Dr. Perci Coelho de Sousa e Newton Narciso Gomes, assim como professora Dra. Silvia Cristina Yannoulas por terem aceito o convite para serem membros das bancas de qualificação, "pré-dissertação" e da defesa final. Suas sugestões e contribuições foram importantes para construção da dissertação. Justifico a não contemplação de algumas ideias, devido a tempo insuficiente ou discordância teórica, mas elas serão levadas em conta, por mim, como aprendizado na continuação de meus estudos sobre política social.

Agradeço também a todos os docentes do PPGPS/SER/IH/UnB, nesse processo de aprendizagem e descobertas, principalmente os que tive o prazer do contato direto, seja enquanto discente das disciplinas ofertadas - Ângela Neves, Ivanete Boschetti, Marlene Teixeira e Newton Narciso Gomes - seja por meio do convívio proporcionado pela representação discente, a qual fui indicada - Lúcia Lopes, Marlene Teixeira e Silvia Yanoulas. A esta última, tão querida, agradeço, adicionalmente, pela compreensão, disposição, atenção, encorajamento, auxilio nas diversas esferas, ou seja, por tudo.

A todos os colegas de curso, ainda mais aos da turma 1/2013, da qual faço parte, cujo convívio e debates ora calorosos, ora divertidos ou mesmo densos, dentro e fora da sala de aula, contribuíram e muito para o avanço de minhas indagações, problematizações e apreensões sobre a realidade. Sobretudo ao nosso grupo, "amigas Bsb", cuja caminhada foi mais próxima, soma-se ainda, os compartilhamentos dos momentos de estudo, distração, alegria, tristeza, insanidade e superação.

A todos os servidores do quadro do Departamento de Serviço Social, principalmente a querida Domingas, pela atenção, paciência e auxilio nos tratos administrativos que tive que recorrer.

À Coordenação de Aperfeiçoamento de Pessoal de Nível Superior (CAPES) pelo apoio financeiro a essa pesquisa, sob a forma de bolsa de estudo.

Um agradecimento especial, de todo o meu coração, à minha família pelo amor incondicional. Filhas amadas, Marina e Helena, vocês são meu porto seguro, meu chão, meu ânimo. A existência de vocês é fonte de energia para mim; perdoem-me o tempo ausente que passei para que esta dissertação fosse edificada. Thiago, marido, amigo e companheiro, obrigada pelo amor, apoio, paciência, compreensão, dedicação a mim e a nossa família. A minha mãe, Nilda, obrigada pela dedicação de uma vida inteira; foi imprescindível a sua vinda a Brasília nessas últimas semanas para me auxiliar no cuidado da Heleninha, diga-se de passagem, foi muito além desse apoio: não fosse por isso, a 
finalização desta dissertação não seria realizada. Pai, em memória, obrigada por todos os anos de companheirismo e amizade, a herança do seu entusiasmo pelo conhecimento e debate permanecem vivos em mim. Amo demasiadamente todos vocês.

Às amigas do peito, obrigada pela amizade verdadeira e sincera, força e encorajamento, em especial por continuarem tão presentes, mesmo que por intermédio do Thiago, diante do meu sumiço. Desculpem-me por não atender telefone fixo ou celular, por não ver e nem responder os e-mails, ou qualquer outra mensagem, e obrigada pela fidelidade a nossa amizade: amigas de infância e adolescência da época da escola, da Nana fest, da graduação em Pedagogia e Serviço Social, ao pessoal de SC, CEAL, VP GSF e os recentes da Casa da Cultura. Também agradeço, em particular, as amigas que se dispuseram e auxiliaram no cuidado das meninas, desde o processo seletivo até o presente momento: Ana, Andréa, Haynara, Larissa, Valyria e Vanessa Raquel. Como disse Shakespeare, os amigos são a família que nos foi permitido escolher.

A todos vocês que fizeram parte desse amadurecimento pessoal, intelectual e acadêmico, muito obrigada! 


\section{LISTA DE ABREVIAÇÕES E SIGLAS}

BPC- Benefício de Prestação Continuada

BRICs- Brasil, Rússia, Índia, China e África do Sul

CEPAL- Comissão Econômica para América Latina e Caribe

CF- Constituição Federal

CNIS- Cadastro Nacional de Informações Sociais

EUA- Estados Unidos da América

FGV- Fundação Getúlio Vargas

FHC- Fernando Henrique Cardoso

FMI- Fundo Monetário Internacional

GSF - Gasto Social Federal

G 20- Grupo dos 20

IPEA- Instituto de Pesquisa Econômica Aplicada

ISI- Industrialização por Substituição de Importações

JK- Juscelino Kubitschek

LOAS- Lei Orgânica de Assistência Social

MAB- Movimento dos Atingidos por Barragens

MDS- Ministério de Desenvolvimento Social e Combate à fome

MTE- Ministério do Trabalho e Emprego

NOB- Norma Operacional Básica

OIT- Organização Internacional do Trabalho

ONU- Organização das Nações Unidas

PCFMV- Plano de Combate à Fome e a Miséria pela Vida

PIB- Produto Interno Bruto

PL- Partido Liberal 
PSB- Partido Socialista Brasileiro

PSDB- Partido da Socialdemocracia Brasileira

PT- Partido dos Trabalhadores

PBF-Programa Bolsa Família

RAIS- Relação Anual de Informações Sociais

SICON- Sistema de Condicionalidades

SUAS- Sistema Único de Assistência Social

TSE- Tribunal Superior Eleitoral

UFRJ- Universidade Federal do Rio de Janeiro

UFRGS- Universidade Federal do Rio Grande do Sul

UnB- Universidade de Brasília 


\section{LISTA DE ILUSTRAÇÕES}

Quadro 1- Características do nacional desenvolvimentismo e do nacional desenvolvimentismo às avessas do governo Lula..... 60

Quadro 2- Crescimento do PIB e PIB per capita. Brasil, 2000-2012 ..............................65

Quadro 3- Composição do governo Dilma no segundo mandato.

Quadro4- Valores dos benefícios em R\$ de acordo com a composição familiar .77

Quadro 5- Valores médios repassados ao Bolsa-família. . .78

Gráfico A- Lucro líquido dos onze maiores bancos .64

Gráfico B- Trajetória do Gasto Social Federal 1995 a 2010. . .73

Gráfico C- Trajetória do aumento dos recursos destinados as políticas da seguridade social de 2003 a 2014.

Gráfico D- Trajetória da dotação inicial em \% destinada as políticas da seguridade social entre 2003 e 2014.

Gráfico E- Divisão em \% dos recursos entre as políticas da seguridade em 2014. .74

Gráfico F- Destinação do orçamento da assistência social em 2014 .75

Gráfico G- Índice de Gini . .76

Gráfico H- Evolução da pobreza segundo o número de pobres. . .76

Gráfico I- Taxas de crescimento real do GSF e do PIB em períodos de crise. . .81

Gráfico J- GSF por área de atuação. .81

Mapa- Desigualdade social mundial. .82 


\section{Nada é impossível de mudar}

Desconfiai do mais trivial, na aparência singelo.

E examinai, sobretudo, o que parece habitual.

Suplicamos expressamente: não aceiteis o que é de hábito como coisa natural, pois em tempo de desordem sangrenta, de confusão organizada, de arbitrariedade consciente, de humanidade desumanizada, nada deve parecer natural nada deve parecer impossível de mudar.

Bertold Brech 


\section{RESUMO}

Busca-se, por meio desta dissertação, discutir sobre a real existência da estratégia denominada "neodesenvolvimentista" iniciada, no Brasil, com o governo de Luís Inácio Lula da Silva, e seguida por Dilma Rousseff, num contexto de crise estrutural do capitalismo global. Busca-se, além disso, demonstrar a ausência dessa estratégia no âmbito das políticas socioassistenciais dos referidos governos. Para tanto, efetuou-se breve resgate histórico do chamado "desenvolvimentismo" nacional e de sua interrupção pela agenda neoliberal entronizada no Brasil após vinte e um anos de ditadura civilmilitar, já que o "neodesenvolvimentismo" propõe-se a ser uma retomada do desenvolvimentismo e um rompimento com o neoliberalismo. Em seguida, recuperou-se o essencial da discussão contemporânea acerca da proposta "neodesenvolvimentista" com vistas a colher subsídios teóricos críticos sobre a mesma. Por fim, mas não menos importante, procurou-se identificar na política de assistência social brasileira, edificada como direito pela Constituição Federal de 1988, a presença de efeitos neodesenvolvimentistas, elegendo-se como unidade empírica de análise o Programa Bolsa Família (PBF). Como resultado da análise empreendida observou-se que a proposta "neodesenvolvimentista" caracterizou-se como medida política de "colaboração de classe", por ter se transformado em versão menos extremada de neoliberalismo. O suposto crescimento econômico, totalmente instável, com melhoramento dos indicadores sociais, deu-se de maneira superficial, reduzindo a pobreza, mas sem tocar na estrutura da desigualdade social. A política de assistência brasileira vive, na atualidade, o seguinte dilema: de um lado, defendendo, discursivamente, o status de direito que lhe foi conferido pela Constituição Federal e, por outro, submetendo-se aos ditames neoliberais que a reduz a mero instrumento de alívio da pobreza por meio de programas de transferência de renda em detrimento da oferta de serviços socioassistenciais.

Palavras-chave: crise capitalista, neodesenvolvimentismo; neoliberalismo; política socioassistencial. 


\section{ABSTRACT}

We seek, through this dissertation, to argue about the actual existence of the strategy called "neodevelopmentist" started in Brazil with the government of Luiz Inacio Lula da Silva, and followed by Dilma Rousseff, in a context of structural crisis of the global capitalism. We seeks, moreover, to demonstrate the absence of that strategy in the context of social assistance policies of those governments. For this, we made up a brief historical review of the so-called national "developmentalism" and its interruption by the neoliberal agenda enthroned in Brazil after twenty-one years of civil-military dictatorship, as the "neo-developmentism" is proposed to be a resumption of developmentalism and a break with neoliberalism. Then, we recovered the essence of the contemporary discussion about the neodevelopmentist proposal in order to gather critical theoretical support on it. Last but not least, we sought to identify, in the Brazilian social assistance policy, built as a right by the Constitution of 1988, the presence of neodevelopmentist effects, electing themselves as empirical unit of analysis of the Bolsa Família Program -PBF (Family Grant Program). As a result of the undertaken analysis, we observed that the neodevelopmentist proposal was characterized as a political measure of "class collaboration" for having become [a] less extreme version of neoliberalism. The supposed economic growth, totally unstable, with the improvement of social indicators, happened superficially, reducing poverty, but without touching the structure of social inequality. The Brazilian welfare policy lives, at this moment, the following dilemma: on the one hand, defending, discursively, the legal status that it was given by the Federal Constitution, and on the other, submitting itself to the neoliberal dictates that reduces it to a mere instrument of poverty alleviation through income transfer programs, over the provision of social assistance services.

Keywords: capitalist crisis; neo-developmentism; neoliberalism; social assistance policy. 


\section{SUMÁRIO}

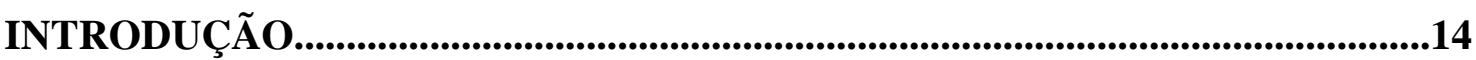

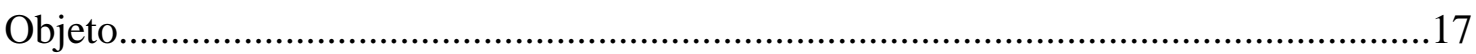

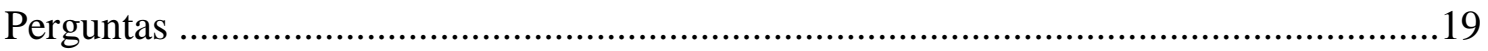

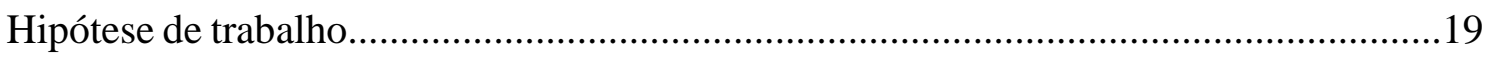

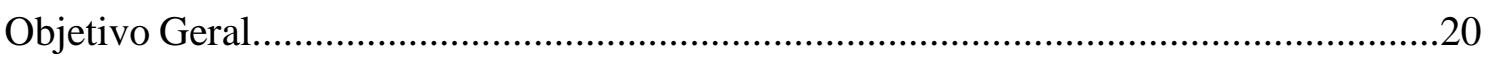

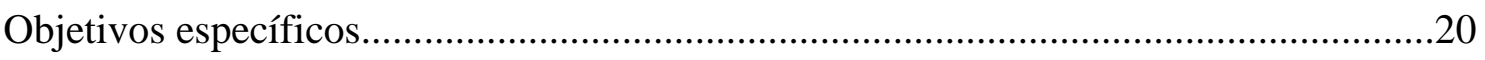

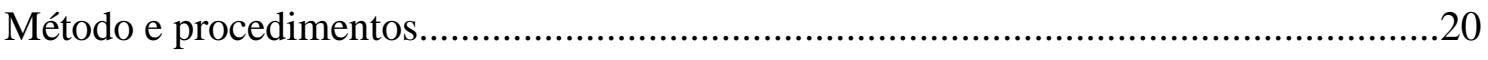

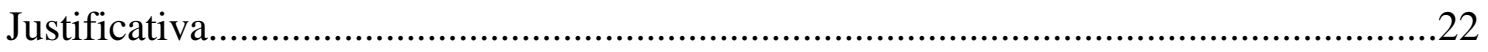

CAPÍTULO 1- REFERÊNCIAS TEÓRICAS E HISTÓRICAS TECIDAS EM TORNO DE CATEGORIAS CENTRAIS DE ANÁLISE ............................................25

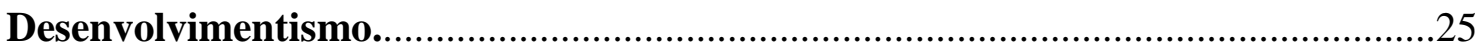

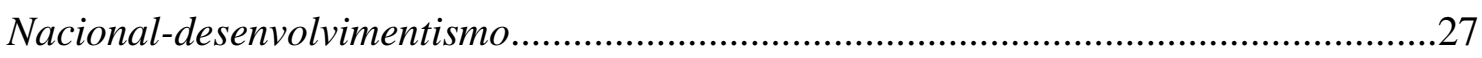

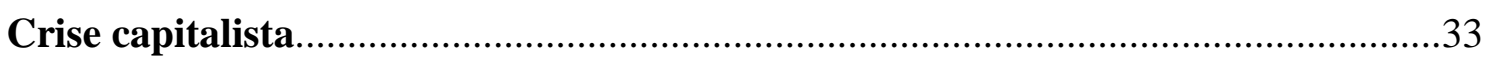

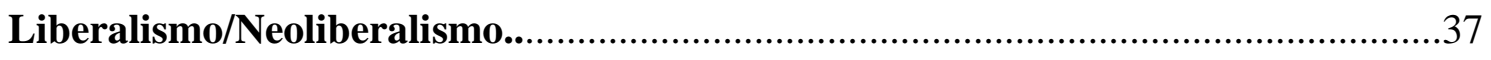

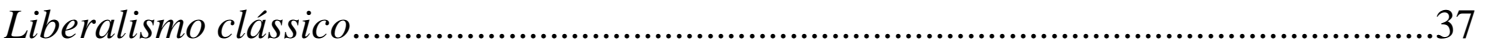

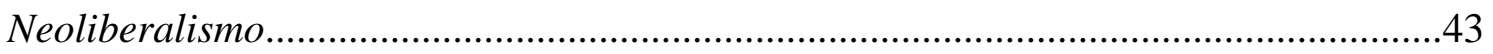

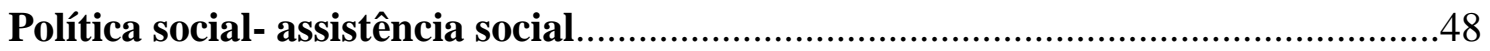

CAPÍTULO 2- EMERGÊNCIA E TENDÊNCIAS DO "NEODESENVOLVIMENTISMO": UMA NEOLIBERALIZAÇÃO EM TEMPO DE CRISE..................................................................................................................................51

2.1Uma invenção latino-americana.........................................................................................51

2.1.1 Surgimento da ideia neodesenvolvimentista no Brasil................................................51

2.2 "(Neo)desenvolvimentismo": utopia ou realidade?.........................................................54

2.3Mais utopia que realidade.................................................................................................58

CAPÍtUlo 3- A POLITICA SOCIOASSISTENCIAL NO CONTEXTO DO NEODESENVOLVIMENTISMO..................................................................................71

3.1Ressignificação da assistência social nos marcos da Constituição Federal de 1988 ....71 
3.2 Crítica aos pretensos avanços neodesenvolvimentistas no campo assistencial............80

A MODO DE CONCLUSÃO

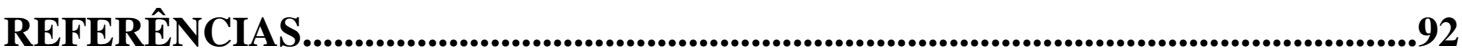

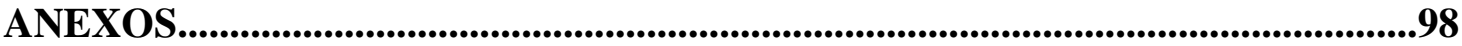




\section{INTRODUÇÃO}

O tema do neodesenvolvimentismo, um neologismo a ser problematizado nesta dissertação, tem raízes estruturais e históricas que transcendem as fronteiras nacionais. Para compreendê-lo, é preciso situá-lo no contexto das mudanças do sistema capitalista que, pressionado por crises inerentes, transitou, nos fins dos anos 1970, de um modelo "regulado" pelo para outro "desregulado", no qual as forças livres do mercado passaram a dominar.

Efetivamente, o mundo capitalista, logo após a Segunda Guerra Mundial, vivenciou, conforme Hobsbawm (1995), os anos dourados/gloriosos, isto é, "uma fase excepcional da história" (p. 253), em que se "realizara a mais impressionante, rápida e profunda revolução nos assuntos humanos de que a história tem registro” (p. 281).

Isso ocorreu devido aquele momento ter sido marcado, segundo Harvey (2012), pelo regime de acumulação keynesiano-fordista. Essa organização política e econômica tinha um Estado que "deveria concentrar-se no pleno emprego, no crescimento econômico e no bem-estar de seus cidadãos, e de que o poder do Estado deveria ser livremente distribuído ao lado dos processos de mercado” (p. 20). Houve, nesse período, nas palavras de Harvey (2012b), um "surto de expansões intercapitalistas" (p.125), que “alcançou taxas fortes, mais relativamente estáveis de crescimento econômico. Os padrões de vida se elevaram, as tendências de crise foram contidas, a democracia de massa preservada e a ameaça de guerras capitalistas, tornada remota" (p. 125). Sua duração foi de 1945 a 1973; posteriormente, esta "Era de Ouro perdeu seu brilho" (HOBSBAWM, 1995, p. 281).

Com efeito, desde o final dos anos de 1960, o capitalismo "regulado" começou a desmoronar. Segundo Harvey (2012), "os sinais de uma grave crise de acumulação eram de toda parte aparentes” (p. 22). De acordo com Mandel (1982), no segundo pós-guerra, denominado pelo autor de "capitalismo tardio", a expansão econômica ocorrida não resolveu as contradições internas desse modo de produção.

A oscilação periódica dos investimentos, determinada pela oscilação periódica da taxa média de lucros, continuou sendo a regra [...] Quanto menor a taxa média de crescimento da produção mundial capitalista, tanto menores as fases de boom e tanto maiores as fases de recessão e estagnação relativa (p. 332). 
Dessa forma, Mandel afirma que entramos em um longo período de estagnação, o que pode ser somando à análise de Mészáros (2009), de que a partir dos anos de 1970, não se estava vivenciando somente uma crise cíclica, mas, "uma crise estrutural do sistema do capital como um todo" (p.17). Isso se torna explícito na seguinte tendência: a crise é universal, a abrangência é global, a duração é permanente e tem desdobramento rastejante. Ou seja, trata-se de "uma crise estrutural [que] afeta a totalidade de um complexo social em todas as relações com suas partes constituintes ou subcomplexos como também a outros complexos aos quais é articulada" (MÉSZÁROS, 2011, p. 797).

Portanto, o que, no máximo, pode acontecer em relação às respostas à crise, de acordo com Mészáros (2011), são "alguns sucessos conjunturais [...] de determinantes cíclicos da crise atual do capital” (p.810), visto que, a direção da mesma é para um aprofundamento e não para uma solução. Isso porque, tem-se uma intensificação dos antagonismos existentes, que possuem como base várias contradições assim sintetizadas pelo autor:

As contradições socioeconômicas internas do capital 'avançado' [...] as contradições sociais, econômicas e políticas das sociedades póscapitalistas [...] as rivalidades, tensões e contradições crescentes entre os países capitalistas mais importantes[...] as dificuldades crescentes para manter o sistema neocolonial de dominação, ao lado das contradições geradas dentro dos países 'metropolitanos'... (p. 808)

Diante desse quadro, a alternativa pensada para a retomada da acumulação do capital foi a substituição do modelo keynesiano de regulação econômica e social pelo monetarismo adotado pela ideologia neoliberal, que, desde então, ganhou espaço e centralidade. De acordo com Harvey (2012), o neoliberalismo diz respeito ao retorno de pressupostos liberais clássicos somados aos princípios neoclássicos de livre mercado. Dessa forma, conforme Cabrero (1982), o que se busca é: "voltar a um mítico mercado que regule as relações econômicas e políticas de acordo com os puros critérios de oferta e demanda" (p.32), uma vez que os neoliberais consideram que a intervenção do Estado com seus gastos sociais põe em risco "o exercício das liberdades políticas e econômicas da sociedade liberal burguesa" (p. 33.)

No que tange à neoliberalização da América Latina, Anderson (1995) informa que esta ocorreu em 1988, no México, no governo de Salinas; em 1989, na Argentina, no governo Menem; e no segundo mandato de André Perez na Venezuela; em 1990, no Peru, na gestão de Fujimori; em 1985, na Bolívia, a partir das eleições de Paz Zamora e, em seguida, com Sanchez Losada. Os governantes do México, Argentina, Venezuela e Peru 
não se fizeram entender sobre a realidade que pretendiam implementar em seus respectivos países antes das eleições. No caso da Argentina e Peru, os governantes fizeram, inclusive, o contrário do que haviam proposto; e, no México, fraudaram-se as eleições. Salinas, Menem e Fujimori conseguiram a implementação do neoliberalismo em seus respectivos países em curto espaço de tempo. No México, isso foi facilitado pelo fato de haver, naquele país, um regime de partido único; e, na Argentina e no Peru, foram criadas legislações, reformas nas Constituições e autogolpes, ao contrário do que aconteceu na Bolívia: ai, a efetivação da neoliberalização se deu por meio de governos eleitos, e não pela via da coerção. Já na Venezuela, a entrada do neoliberalismo não ocorreu com muito êxito; neste país, o autoritarismo político utilizado em alguns dos países anteriormente citados, não se fez possível, devido a uma democracia partidária não apenas forte, mas também consolidada.

A neoliberalização brasileira foi tardia, se comparada com os demais países latino americanos, dadas as suas particularidades históricas. Segundo Sader (2013), o golpe militar desferido no país, em 1964, se diferenciou por ter ocorrido no "ciclo longo expansivo do capitalismo" (p.137), diferentemente dos outros países da América Latina, que passaram por ditaduras no "ciclo longo recessivo da economia mundial" (p. 137). Dessa maneira, o Brasil conseguiu obter ganhos sucessivos em sua taxa de crescimento, mesmo que reprimindo as formas de organização da classe trabalhadora e arrochando salários. No período ditatorial, apesar da expressiva entrada de capital estrangeiro no país, não houve enfraquecimento econômico. Entretanto, a crise da dívida externa, mais os acordos com o FMI, fizeram com que o Brasil abdicasse de um projeto de desenvolvimento.

\begin{abstract}
A expressão interna da crise dos anos 80 no Brasil se dá no chamado esgotamento do Estado desenvolvimentista, cujo padrão se baseava no tripé Estado - capital estrangeiro - capital nacional, com surtos de crescimento e desenvolvimento que possibilitavam os movimentos de 'fuga para frente', em que se acomodavam os diversos interesses dominantes (SOARES, 2009, p. 35).
\end{abstract}

Assim, a nação tornou-se análoga a dos outros países da região, tornando-se também neoliberal, fazendo escolhas políticas e econômicas sob a égide dos governos Collor de Mello e Fernando Henrique Cardoso. O "ajuste neoliberal [adotado nesses governos] não [foi] apenas de natureza econômica: [fez] parte, [ como se fez acontecer em outros lugares], de uma redefinição global do campo político institucional e das 
relações sociais" (Id., p. 12). Dessa forma, produziu um quadro socialmente crítico, que pode ser assim descrito:

\begin{abstract}
As consequências da incorporação do ideário neoliberal nas sociedades, que como a brasileira, vivem os impasses de consolidação democrática, do frágil enraizamento da cidadania e das dificuldades históricas de sua universalização, expressam-se pelo acirramento das desigualdades sociais, encolhimentos dos direitos sociais e trabalhistas, aprofundamento dos níveis de pobreza e exclusão social, aumento da violência urbana e da criminalidade, agravamento sem precedentes da crise social que, iniciada nos anos 80 , aprofunda-se continuadamente na primeira década do século XXI (RAICHELIS, 2006, p.4)
\end{abstract}

Contudo, a vitória da candidatura para presidente da República de Luis Inácio Lula da Silva, em 2002, após três candidaturas consecutivas derrotadas (1989, 1994 e 1998), trouxe esperanças e questionamentos quanto à direção política e econômica que o Brasil iria seguir a partir de seu mandato, que se iniciaria em 2003; isso porque, esse candidato representava as forças políticas da esquerda brasileira, por intermédio do Partido dos Trabalhadores (PT). É justamente sobre os mandatos dos presidentes Luís Inácio Lula da Silva (2003/2007-2007/2010) e Dilma Rousseff (2011-2014), também do PT, reeleita em 2014 para mandado até 2018, que, nesta Dissertação, serão analisadas as características assumidas pela política social, em especial as mudanças ocorridas no campo socioassistencial brasileiro, tendo como unidade de análise o Programa Bolsa Família.

É, portanto, nos governos de Lula e Dilma que se inscreve o objeto de interesse privilegiado desta Dissertação, o qual pode ser assim especificado: trata-se dos limites e alcances da política governamental dos referidos governos, denominada de neodesenvolvimentista, identificáveis na relação entre políticas socioassistenciais, representadas pelo Programa Bolsa Família (PBF), e os imperativos neoliberais que negam a intervenção social do Estado; ou melhor, trata-se da relação aparentemente contraditória entre uma política de conteúdo social, que exige intervenção do Estado e um ideário dominante que elege o livre mercado, o crescimento econômico e a autossustentabilidade dos indivíduos como os principais mecanismos de desenvolvimento da nação.

Sobre os referidos governos, é voz corrente, que eles se pautaram pela diretiva de um novo desenvolvimentismo; isto é, pela retomada consciente e planejada do processo de desenvolvimento que ocorreu no Brasil, a partir dos anos 1930, com o governo Vargas, e prosseguiu, nos anos 1950, ainda com Vargas (até 1954), Juceslino 
Kubistchek e até mesmo com João Goulart, que foi deposto pelo golpe civil/militar em 1964.

Segundo Castelo (2012), "a ideologia desenvolvimentista voltou repaginada à cena - acoplada dos prefixos 'novo' e 'social' - e tornou-se o tema da moda no Brasil"' (p. 614). Esse retorno, segundo o autor, está baseado no fato de o país ter aumentado suas taxas de crescimento no mesmo passo em que houve a melhora de alguns indicadores sociais, principalmente os relacionados à pobreza extrema.

O panorama desenhado pelos defensores do (neo) desenvolvimentismo sobre o desenvolvimento recente do Brasil, apoia-se, segundo Fonseca, Cunha e Bichara (2012), na economia que cresceu 7,5\%, em 2010 - mesmo em um momento de crise global - indo, dessa forma, além das prospecções tanto do governo quanto do mercado. Quanto à inflação esta se manteve em baixa, chegando à deflação em 2009 e, posteriormente, ficando dentro dos limites estipulados pelo Plano de metas do governo. O desequilíbrio externo foi entendido como inexistente, já que, em 2010, as reservas internacionais chegaram a US\$ 288,5 bilhões. Isso ocorreu ao mesmo tempo em que houve mudanças positivas no quadro social brasileiro. Análise do IPEA, (2011), referente aos anos de 2004 a 2009, revela que as mudanças ocorridas no terreno da pobreza ${ }^{1}$, no país, recaíram sobre a distribuição da renda, pois o coeficiente de Gini diminuiu ${ }^{2}$ 0,43 até 2009 se comparado aos 5,6\%, em 2001. Afirma-se, ainda, que a política social teve bastante fôlego com o aumento real ${ }^{3}$ do salário mínimo e com o aumento de transferências focalizadas ${ }^{4}$ de renda, por meio de benefícios sociais públicos, como os proporcionados pelo Benefício de Prestação Continuada (BPC) e Programa Bolsa Família.

No entanto, esse panorama é contraditado por análises, como as de Sampaio Jr. (2012), que afirma haver uma discrepância entre o que é na prática e o que se diz ser. Para este autor, o (neo) desenvolvimentismo acredita (nas pessoas de seus defensores) que é "uma alternativa qualitativa do desenvolvimento capaz de resolver os problemas renitentes da pobreza e da dependência externa" (p.685). Mas, o que se apresenta na

\footnotetext{
${ }^{1}$ Pobreza é entendida apenas pelo recorte de renda, o que camufla a sua extensão real.

${ }^{2}$ Mas, apesar da diminuição da desigualdade social- pequena, diga-se de passagem - o Brasil ainda é uma das nações mais desiguais do mundo.

${ }^{3}$ Segundo o IBRE o salário mínimo teve ganho real de 72,31\% de 2002 a 2014.

4 A assistência social passou de menos de 4\% do orçamento da seguridade social em 2000 para aproximadamente $10 \%$ em 2013, sendo a maior parte da destinação dos recursos para o BPC e o PBF (dados Siga Brasil). A extensão do PBF, segundo o MDS, era de 13,8 milhões de famílias até dezembro de 2013.
} 
prática, é "apenas uma versão da surrada teoria do crescimento e da modernização acelerada como solução para os problemas do Brasil” (Id. Ib.). Tem-se, assim, um discurso neodesenvolvimentista cujo papel configura-se como "arma ideológica dos grupos políticos entrincheirados nas estruturas do Estado" (pp.685/686), combinado com o esforço de "reforçar o mito do crescimento como solução para os problemas do país" (p.686). Afinal, como diz Paula (2005): "a história do desenvolvimento social brasileiro é a história do precário e desigual desenvolvimento da modernização capitalista e também a história da interdição de direitos sociais básicos para parte significativa da população" (p. 8).

É no contexto desta problemática que se perfilam as seguintes perguntas de pesquisa desdobradas do objeto:

a) Em que medida as estratégias brasileiras denominadas "neodesenvolvimentistas" conseguem conciliar os esforços governamentais de promover o crescimento econômico com erradicação da pobreza extrema e, eventualmente, a redução da desigualdade social? b) Qual o lugar/papel da política de assistência social e, dentro desta, do Bolsa Família nessa possível conciliação?

Com base nestas questões que, por sua vez, compõem a problemática da investigação tornou-se possível formular, como recurso heurístico, a hipótese de trabalho a seguir apresentada, lembrando que ela é uma conjectura ou afirmação provisória, e, ainda, o "começo de conversa", no dizer de Alves (2011, p.4), que foi construída com o objetivo de orientar o percurso analítico. Por isso, ela, implicitamente, contém possíveis respostas a serem confrontadas com a realidade.

\section{Hipótese de trabalho}

Supõe-se que, no contexto do projeto neodesenvolvimentista brasileiro, a conciliação entre crescimento econômico e combate à pobreza extrema dá-se de maneira desigual entre interesses econômicos e sociais, contribuindo prioritariamente, para a satisfação das necessidades de lucro do capital em vez das necessidades sociais. Trata-se, portanto, o projeto neodesenvolvimentista, de um continuísmo do neoliberalismo revestido de uma preocupação social por governos provenientes do campo da esquerda. $\mathrm{O}$ PBF entra nesse processo como uma estratégia de combate à pobreza que não conflita com os prioritários interesses governamentais de crescimento da economia; muito pelo contrário, consegue diminuir marginalmente a pobreza extrema sem romper, de fato, com a desigualdade social. 
Em vista do exposto, a pesquisa teve como objetivo geral:

Identificar as características da política governamental dos governos Lula e Dilma, autodenominada de neodesenvolvimentista, para desnudar:

- A ideologia que sustenta a referida política e informa a concepção de desenvolvimento adotada;

- As contradições implícitas na estratégia governamental de pretender (ou ser obrigada a) conciliar liberalismo (de caráter privatizante e socialmente descomprometido) com intervencionismo estatal (de caráter publicizante e socialmente referenciado);

- As injunções sofridas pelas políticas socioassistenciais nesse processo.

\section{E, como objetivos específicos:}

- Analisar a relação entre desenvolvimentismo e (neo)desenvolvimentismo no Brasil nos seus respectivos contextos históricos, e filiações teórico-ideológicas;

- Detectar o poder de influência da ofensiva neoliberal nos governos Lula e Dilma e de sua presença nas estratégias de combate à pobreza no Brasil dos últimos doze anos;

- Identificar as principais restrições sofridas pelas políticas socioassistenciais (previstas na Constituição Federal vigente) nos referidos governos;

- Analisar a utilização neoliberal do Programa de Transferência de Renda "Bolsa Família";

- Verificar em que proporção a política "neodesenvolvimentista" no Brasil atende as necessidades sociais e as do capital

\section{Método e Procedimentos}

Todo o conhecimento obtido por meio desta pesquisa está fundamentado na realidade social. Logo, a pesquisa não se baseou em um método construído previamente, já que, em consonância com o paradigma dialético materialista histórico pelo qual ela se orientou, foi essa realidade que informou o método mais apropriado para desvendá-la. Trata-se de uma realidade que, de acordo com Ianni (1991), está sempre "em movimento, 
formação e transformação" (p.10), não se fazendo óbvia, pois o que se apresenta em primeira instância ao/a observador/a não condiz completamente com ela própria.

Esse entendimento foi crucial na escolha do método por evitar posturas cartesianas no trato da realidade pesquisada, e por prover o esclarecimento de que é esta realidade, e não o método, que é dialética. $\mathrm{O}$ método torna-se dialético ao se amoldar à dinâmica, às sinuosidades e às contradições dessa realidade, permitindo ao/a pesquisador/a ficar imune à ilusão fetichista das aparências do seu objeto de estudo. Com essas características, o referido método também não é neutro; ele, assim como o paradigma que o orienta, estimula a crítica social com vistas à mudança. E, nesse sentido, possibilita uma relação de mútua implicação entre sujeito e objeto da investigação.

Nesta dissertação, a escolha do método histórico- dialético se deu por se acreditar que ele é o mais indicado para a apreensão de um objeto que é processual, estruturalmente determinado, e político e historicamente situado. Nele, a ideologia desenvolvimentista e as políticas socioassistenciais, inserem-se no capitalismo de extração liberal; tais políticas, como se sabe, advêm de relações complexas e contraditórias entre Estado e sociedade e são partes integrantes da dinâmica de produção e (re)produção da ordem burguesa. Entende-se, portanto, que esta compreensão é essencial para justificar o método escolhido nesta investigação.

Quanto aos procedimentos metodológicos, isto é, aos meios de obtenção de subsídios disponíveis em fontes selecionadas, cabe ressaltar que eles também se pautam por matrizes teóricas construídas a partir do real, matrizes essas que iluminam material recolhido pelo/a pesquisador/a, imprimindo-lhes sentido (HAGUETE, 2003, p. 175).

Sabe-se que diversos são os instrumentos e técnicas de investigação. A escolha da principal técnica usada na presente pesquisa foi a análise documental que, segundo Marsiglia (2006), é “dirigida a textos escritos que podem servir como fonte de informação". Esse texto tem várias configurações: "planos, programas, leis, decretos, artigos, atas, relatórios, ofícios, documentos, panfletos, etc.” (p. 11). Nesta pesquisa, os dados e informações que informam o conteúdo desta dissertação - tanto no que diz respeito à discussão sobre as influências ideológicas sobre a política neodesenvolvimentista brasileira recente, quanto no que se refere aos efeitos dessa política sobre as práticas socioassistenciais adotadas - foram obtidos principalmente nas seguintes fontes secundárias ou indiretas: consultas a legislações da área; diversas 
publicações acadêmicas de artigos em revistas e livros do tema, como, de programas de pós graduação, ser social, serviço social e sociedade, revista de economia política dentre outras e de meios de comunicação, como jornal dos economistas, em especial do blog marxismo 21. Assim como, dados do IPEA via comunicados do IPEA nº 111, 155, $159 \mathrm{e}$ nota técnica Disoc; Base de dados do governo federal, Siga Brasil e do PBF; Banco Mundial e documentos OIT, etc.

A análise dos dados e informações coletados teve caráter mais qualitativo do que quantitativo, por se apoiar, predominantemente, nos discursos, nas falas, nos valores, nos projetos registrados, com vistas a confrontá-los com as práticas e resultados das efetivas ações governamentais. Entretanto, a predominância da análise qualitativa não se pautou por uma opção pessoal, e sim pela própria índole relacional e ideológica do objeto, difícil de ser quantificada, embora, no conjunto do processo analítico, a dimensão quantitativa e não tenha ficado ausente. Esse procedimento procurou estar de acordo com a perspectiva dialética que, "ao mesmo tempo tenta conceber todas as etapas [e fontes] da investigação e da análise como partes do processo social analisado e com uma consciência crítica possível” (MINAYO \& SANCHES, 1993, P. 244)

Por fim, a justificativa da escolha do tema e do objeto baseia-se na ocorrência e culminância de alguns momentos:

O primeiro se deu com a participação, como bolsista, da autora desta dissertação, no Projeto de Extensão e Ação Contínua "Quintas Urbanas" do Departamento de Serviço Social da Universidade de Brasília, no período compreendido entre o $1^{\circ}$ semestre de 2009 e o $2^{\circ}$ semestre de 2011. Esta experiência permitiu-lhe contato e trabalho direto com o Movimento dos Atingidos por Barragens (MAB), existente no Brasil há mais de 20 anos, cuja luta centra-se na defesa do direito dos atingidos pelas barragens a permanecerem nas terras que eram suas. O contato, vivência e participação no MAB despertaram-lhe o conhecimento das consequências sociais da adesão do Brasil ao neoliberalismo. Foi, portanto, essa experiência que, além de prover conhecimentos e estímulos à crítica social, revelou, com nitidez, a esta pesquisadora, a face complexa, contraditória e antissocial do processo de autovalorização do capital.

O segundo momento ocorreu com a realização das disciplinas Estágio I e II, entre março de 2010 a março de 2011, no Departamento de Assistência Social da Federação Espírita Brasileira. Essa experiência proporcionou vivência e análise do 
exercício profissional da assistente social e suas intervenções junto aos usuários da Proteção Social Básica da Política de Assistência Social e instigou esta pesquisadora a entender a relação das políticas sociais com a conjuntura contemporânea.

O terceiro momento aconteceu com o processo de construção da Monografia “A refamilização da assistência social brasileira sob a égide neoliberal”, cujas orientações, discussões e revisão bibliográfica sobre o assunto auxiliaram na obtenção de uma visão mais clara da realidade e, consequentemente, na formulação de novos e mais profundos questionamentos.

O quarto momento foi o ingresso desta pesquisadora, no primeiro semestre de 2013, no Mestrado do Programa de Política Social, do Departamento de Serviço Social da UnB, cujas disciplinas cursadas, somadas às reflexões e debates com estudantes e professores, abriram um leque de temas e questões atuais, relevantes e instigantes. A escolha do tema desta dissertação e da problemática na qual ele se situa nasceu nesse contexto. A relação do chamado neodesenvolvimentismo brasileiro com o ideário neoliberal dominante, em âmbito mundial, revelou-se o pano de fundo essencial para o entendimento mais fecundo da política socioassistencial no Brasil em tempos de crise do sistema do capital. Crise esta que, conforme Mészáros (2011), é sistêmica; ou melhor, não é apenas econômica ou financeira, mas global, incidente em todas as áreas da vida humana. Trata-se, conforme a interpretação de Antunes do pensamento de Mészáros, (2011) de uma

crise endêmica (...), cumulativa, crônica e permanente, com a perspectiva de uma 'crise estrutural cada vez mais profunda', ao contrário da sua conformação anterior cíclica, que alternava fases de desenvolvimento produtivo com momentos de 'tempestade'. [E que,] com a irresolubilidade da crise estrutural fazendo emergir na sua linha de tendência já visível, o espectro da destruição global da humanidade, a única forma de evitá-la é colocando em pauta a atualidade histórica da alternativa societal socialista, da ofensiva socialista (p. 18, grifos do autor).

Nesse sentido, busca-se, com esta dissertação, contribuir com o fomento do debate de ideias e maior compreensão da atualidade histórica do capitalismo, como um instrumento de luta por um novo mundo.

A dissertação está estruturada em 3 capítulos, além da introdução e considerações finais. No seu primeiro capítulo, são indicadas e explicitadas os conceitos ou categorias analíticas-chave que constituem o eixo teórico desta Dissertação. Em torno 
delas procede-se a uma revisão básica da literatura especializada que referencia o conteúdo dos capítulos subsequentes, associados a fatos e contextos históricos. Foram elas, organizadas em chaves, é abordado primeiramente, o desenvolvimentismo, ligado a esse está a seção nacional-desenvolvimentismo; em seguida, crise capitalista; posteriormente a chave liberalismo, foi essa dividida, nas seções liberalismo clássico e neoliberalismo; E, por fim, a demarcação do entendimento que se tem sobre política social- assistência social. No capítulo segundo, se fez uma análise sobre a origem do “(neo)desenvolvimentismo" e seu desenvolvimento no país, visou-se evidenciar a neoliberalização em curso, levada sob domínio do PT, em tempo de crise, com vistas a desmistificar a utopia que se colocou como realidade. E por fim, no terceiro capítulo, é apresentado os supostos avanços, assim como as ressignificações em curso da política socioassistencial brasileira sob égide neoliberal, colocada, como sendo de caráter “(neo)desenvolvimentista”. 


\section{CAPÍTULO 1}

\section{REFERÊNCIAS HISTÓRICAS E TEÓRICAS TECIDAS EM TORNO DE CATEGORIAS CENTRAIS DE ANÁLISE}

As categorias que se seguem cobrem, em largos traços, o conjunto dos temas e questões que estão no cerne deste estudo, a saber: desenvolvimentismo; nacional desenvolvimentismo; crise capitalista; Liberalismo/neoliberalismo; política social/assistência social. São categorias que, na realidade, estão interligadas e, às vezes, se interpenetram na sua definição. A abordagem separada de cada uma ou conjunto dual, obedece um requerimento didático. A categoria mais central, neodesenvolvimentismo, que deriva do desenvolvimentismo, será tratada à parte, no segundo capítulo.

\section{Desenvolvimentismo}

O desenvolvimentismo como pensamento estruturado na América Latina, surge por meio da Cepal (Comissão Econômica para América Latina e Caribe), anteriormente ligada à Organização das Nações Unidas (ONU). De acordo com Marini (2010), a marca desse pensamento original sobre a América Latina se deu via o Informe Econômico para a América Latina, em 1949, divulgado pela Cepal. Os maiores intelectuais do período ligados a esse pensamento foram: Raul Prebisch, Celso Furtado, Aníbal Pinto, Aldo Ferreiro e Victor Urquidi.

A Cepal tinha como objetivo publicizar a teoria do desenvolvimento originária da Europa e dos Estados Unidos no segundo pós-guerra. O cerne dessa teoria era o entendimento de que o subdesenvolvimento econômico constituía uma fase antecedente do desenvolvimento pleno; e se as nações buscassem as condições necessárias poderiam alcança-lo. Para tanto, fazia-se necessária a modernização econômica, social, institucional e ideológica, que apresentaria, durante certo período, uma dualidade estrutural de oposição entre o setor moderno e o tradicional.

O subdesenvolvimento seria quantificado mediante indicadores que classificariam as economias das nações não desenvolvidas, assim como as suas melhorias rumo ao desenvolvimento. Entretanto, para além de publicizadora de uma teoria imperialista do desenvolvimento, a Cepal tinha um papel importantíssimo nessa função por inaugurar uma ideologia que compreendia a realidade e as particularidades latino- 
americanas, na qual as contradições de classe e as relações centro-periferia estavam expressas. Dessa forma, a referida ideologia

será instrumentalizada pela burguesia industrial, tanto em função das lutas sociais e políticas internas como dos conflitos estabelecidos ao nível da economia mundial. Isso fará com que a Cepal, partindo da teoria do desenvolvimento nos termos em que havia sido formulada nos grandes centros, introduza nela as mudanças que representarão sua contribuição própria, original, e que farão do desenvolvimentismo latino-americano um produto em si, e não uma simples cópia da teoria do desenvolvimento (MARINI, 2010, p.107).

Com efeito, a principal contribuição da Cepal em torno da disjuntiva desenvolvimento/subdesenvolvimento, foi a crítica à teoria neoclássica do comércio internacional, que advogava o prevalecimento do princípio das "vantagens comparativas", segundo o qual cada país deveria se especializar em setores da economia em que fosse mais eficiente, o que gerou deterioração dos termos de intercâmbio. Ou seja, os países subdesenvolvidos que se especializavam em produtos primários (agrícolas e minerais) e comercializavam esses produtos com os países desenvolvidos, especializados em produtos industriais, não obtinham vantagem econômica com esta transação. Pelo contrário, mantinham-se dependentes dos países industrializados. A proposta cepalina para a superação desse desequilíbrio perverso era o de industrializar os países latinoamericanos. Nas palavras de Carcanholo (2010), os países da América Latina deveriam partir para uma

industrialização planejada e implementada por ações estatais - em detrimento dos sinais de mercado, como pregava e continua pregando o pensamento ortodoxo. Ou seja, tratava-se de uma proposta nacionaldesenvolvimentista (p. 120).

Mesmo havendo muitas interpretações acerca do desenvolvimento, o que havia de comum entre elas, caracterizando as ideias desenvolvimentistas, era, segundo Castelo (2010):

(i) a defesa da autonomia e da soberania nacionais; (ii) a industrialização como meio mais eficiente para a superação dos entraves ao desenvolvimento da periferia; (iii) o Estado entendido como um agente estratégico promotor de políticas de planejamento e bemestar social; (iv) a participação ativa de uma intelligenítzia culta e bem formada na gerência de pontos chave do Estado (p.193).

Vale ressaltar que, com a "contaminação" do neoliberalismo na América Latina, a CEPAL necessitou fazer uma análise e se posicionar frente à nova conjuntura, 
caracterizada por reformas do Estado, predomínio do mercado e da financeirização da economia. Segundo Mota, Amaral \& Peruzzo (2012), "a CEPAL passa a se alinhar às propostas de mercado, 'perspectiva revisionista' (p. 156). E assim, o neodesenvolvimentismo nasce como "Terceira Via".

\begin{abstract}
A ideia-força que a Cepal desenvolve é que não existe conflitualidade entre dinamismo econômico e igualdade social. E, portanto, as condições para que essa relação seja equilibrada dependerão das iniciativas que potencializem capacidades humanas e mobilizem energias a partir do Estado (p. 157).
\end{abstract}

\title{
Nacional-desenvolvimentismo
}

Segundo Gonçalves (2012), o desenvolvimentismo no Brasil enfatizou o "nacionalismo, [o] intervencionismo e [a] defesa da indústria" (p. 651). Daí a sua denominação de nacional-desenvolvimentismo, o qual foi marcado por um capitalismo dependente do capital estrangeiro.

O nacional-desenvolvimentismo, conforme Castelo (2012), iniciou-se no Brasil como experiência política, com Getúlio Vargas, no âmbito estadual, em 1928, no Rio Grande do Sul; e, em âmbito nacional, em 1930. Coutinho (2008) informa que Vargas auxiliou na solidificação da transição do Brasil para o capitalismo, pois, após a abolição e a proclamação da República, o país tornou-se uma sociedade capitalista, com um Estado burguês. Contudo, para se apreender aquele momento da história, faz-se necessário caracterizar o Estado brasileiro um pouco antes dos anos 1930. O país era "uma formação político-social do tipo 'oriental', na qual o Estado é tudo e a sociedade civil é primitiva e gelatinosa" (Idem, p. 107).

Quando o país caminhou para a modernidade, prossegue Coutinho, ele se deparou com algumas particularidades: não houve rupturas com a independência do Brasil colônia de Portugal. A independência brasileira não foi uma revolução, pois foi mantida a ordem estatal e socioeconômica, havendo, assim, uma reorganização entre as diversas frações das classes dominantes. A independência brasileira foi gerada de cima para baixo; não foi resultado de movimentos republicanos e populares: "a nação brasileira foi construída a partir do Estado e não a partir da ação das massas populares” (p.111). Dessa forma, as questões populares e as questões nacionais não convergiam, resultando 
no fato de não haver possibilidade de "nossas 'elites', além de dominantes, fossem também dirigentes" (p.111).

Para o Brasil, a independência não significou efetiva emancipação econômica, senão que a confirmação da dependência brasileira da Inglaterra, que se lembre, já submetia Portugal como sua colônia informal, desde o século XVII (SIDERI, 1970 apud PAULA, 2005)

Segundo Paula (2005), o ano de 1850, foi de suma importância, pois marcou o início das imposições do mercado capitalista brasileiro por meio de dispositivos legais que controlavam a ordem social competitiva e visavam garantir/resguardar os interesses do senhoriato oligárquico, tais como: a Lei de Terras; a Lei Eusébio de Queiroz; e a promulgação do Código Comercial Brasileiro. Nas palavras do autor:

Esse senhoriato, apegado aos seus crônicos privilégios, principalmente ao latifúndio e à escravidão, buscou a linha de menor resistência - uma modernização sem mudança- que, apropriando de certos aspectos da modernização capitalista em curso, conservou, no essencial, a velha ordem oligárquica, herança do período colonial e suas características centrais- a economia voltada para a exportação de produtos primários; a concentração da renda e da riqueza; a débil capacidade de gerar processo tecnológico e aumentos de produtividade; o mercado interno restrito. (p. 19)

Somando-se a tais dispositivos legais ainda se tem, em 1891, a Constituição e, em 1916, Código Civil, que serviram para solidificar o Estado burguês no Brasil, no mesmo passo em que foi totalmente hostil com relação a direitos sociais, pois, somente tratou de garantir os direitos da propriedade privada:

os aspectos modernizantes presentes na abolição e na instauração da república, acabaram por estiolarem-se, seja pela ausência ... de uma Reforma Agrária que efetivamente completasse o processo de abolição, no sentido democrático e popular, seja pela imposição de uma ordem republicana que buscou garantir, essencialmente, os direitos individuais, os direitos da propriedade privada numa sociedade marcada por desigualdade social extrema (p. 21).

Os republicanos responsáveis pelo processo de fundação da República brasileira, denominada Republica dos fazendeiros, eram divididos em dois grupos - os positivistas e os da coalização dos representantes das oligarquias regionais. Assim, "a defesa dos interesses dos setores exportadores de produtos primários (...), reiterava a velha estrutura de dependência, que vinha desde o período colonial que o império preservou” (p. 22). 
Sobre a conjuntura desse período, Marini (2012), discorre sobre o processo de industrialização no país, que vinha ocorrendo desde os anos de 1910. A Primeira Guerra Mundial acabou por fazer com que a economia do país se empenhasse na substituição das importações; e a crise de 1929, com suas consequências no mercado internacional, fez com que a industrialização recebesse maior impulso. Castelo (2012), explana sobre esse processo da seguinte forma: "[a industrialização] começou sob o impulso de iniciativas estatais, com políticas protecionistas, de empréstimos e isenções fiscais para investidores privados, que então alocavam seus capitais nos setores de bens de consumo não duráveis" (p. 619). Marini (2012), por sua vez, ressalta que essas transformações acabaram por culminar na criação de uma burguesia industrial voltada para o mercado interno e de um novo proletariado. Ambos buscavam um lugar na sociedade política e entraram em conflito com os grupos dominantes de outrora, conseguindo, por meio da Revolução de 1930, o Estado Novo, em 1937. Desde então, “a burguesia se estabiliza no poder, em associação aos latifundiários e aos velhos grupos comerciantes, ao mesmo tempo em que estabelece um esquema particular de relações com o proletariado" (Id. p. 75).

Segundo Boschetti \& Behring (2008), com a Constituição de 1937 e a Consolidação das Leis Trabalhistas, nas quais se "ratificava a necessidade de reconhecimento da categoria de trabalhadores pelo Estado [fica selado] o modelo corporativista e fragmentado o reconhecimento dos direitos no Brasil” (p. 108).

E, assim, o capitalismo foi se edificando e se consolidando no país. Castelo (2012) chama a atenção para o fato de que, concomitantemente, permaneciam as estruturas coloniais.

A formação econômica-social brasileira foi forjada pelo desenvolvimento desigual e combinado entre distintos modos de produção, no qual os capitalismos detêm o controle econômico, político e cultural frente aos demais (p.620).

Marini (2012) informa que o cenário brasileiro pouco se modificou. Mesmo com a saída de Getúlio Vargas do poder, em 1945, foi mantido o compromisso político de outrora, até 1950, quando Vargas retorna pelo voto e se iniciaram várias lutas políticas, exaurindo-se as condições do pacto feito outrora, "com crescimento constante do setor industrial e [...] dificuldades aparecidas no setor externo" (p. 75). O quadro daquele momento passou a ser o de atividades agroexportadoras versus desenvolvimento industrial, somado às pressões das massas, rumo a conquistas sociais. A passagem para 
os anos seguintes, foi marcada por conflitos; e, como resultado das correlações de forças, Vargas optou por uma política progressista/nacionalista. Dessa maneira, e segundo Castelo (2012), configurou-se no Brasil, nos anos 1950 e 1960, o auge do desenvolvimentismo, marcado pelo capital financeiro.

Entretanto, com os fortes conflitos políticos verificados no país à época, Vargas acabou por se suicidar em 1954. Com esse fato, segundo Marini (2012), houve "uma trégua e não uma solução" (p.80). Intentou-se um compromisso entre as classes, com Café Filho, que era do Partido Socialista, mas que tinha, em vários Ministérios, representantes da direita. Porém, há de se ressaltar a edição, no referido governo, da Instrução 113 que, apesar de não mudar o sistema de câmbio da época, possibilitava a entrada de capitais estrangeiros. Assim, máquinas/ equipamentos foram trazidos para o país por meio de empresas estrangeiras, que não necessitavam de cobertura cambial, obrigatória para as empresas nacionais. Dessa maneira, a burguesia industrial brasileira

tomava uma posição frente à crise que surgira no setor externo. Agoniada pela escassez de divisas, que ameaçava colapsar todo o sistema industrial, a burguesia aceitava que as divisas necessárias para a superação dessa crise fossem fornecidas pelos grupos estrangeiros, concedendo-lhes, em troca, uma ampla liberdade de entrada e de ação e renunciando, portanto, à política nacionalista que havia sido esboçada por Vargas (Id. p.81).

De acordo com Marini, Juscelino Kubitschek (JK) - o então novo presidente da República - apresentou, em 1956, o Plano de Metas do governo. Este tinha como base investimentos públicos, tanto nos setores básicos quanto na entrada de capital estrangeiro; e, assim, Brasília, ou melhor, sua construção, entrou em cena. Segundo Castelo (2012), JK “operou a fusão de um novo bloco de poder no país, baseado no tripé burguesia internacional, burguesia brasileira e Estado" (p. 620). Mas, no que tange às relações de classe, houve, para Marini (2012), uma crescente solidariedade entre as mesmas, visto que no referido governo

a indústria tinha permitido, sem protestar, que boa parte do aumento da produtividade urbana fosse transferida para o setor agroexportador, por intermédio da mecânica dos preços, como incentivo às atividades desse setor; e que também tenha aceitado a política de armazenamento do café (p. 83/84).

Contudo, conforme o autor, houve, ao mesmo tempo, contradições entre o setor agrícola e o setor industrial. Irrompeu, a partir dos anos de 1960, “o binômio política 
externa independente e reforma agrária" (p. 86). Afinal, por meio do arrendamento da terra se fez transferência da riqueza produzida no campo para os grandes proprietários, sendo a transformação tecnológica a agravadora desse processo. A luta pela Reforma Agrária que ganhava corpo, passou a ser "um dos fatores mais importantes de luta de massa no Brasil”" (p. 87). Conforme Almeida (2012), a Liga Camponesa ganhou espaço e tencionou as relações entre burguesia agrária e o Estado.

Mas, o presidente Jânio Quadros (janeiro a dezembro de 1961) assumiu o poder com toda a sua ambiguidade e com o seu bonapartismo carismático, no dizer de Marini (2012), e não realizou a Reforma Agrária. Para o autor, Quadros, em suas tentativas de implementação de um governo forte, abriu "tantas frentes, que despertaram o descontentamento dos mais distintos setores" (p. 95), que precipitaram a sua renuncia do governo. Porém, este foi um estratagema que não funcionou, visto que o presidente pensava ser demovido de seu ato; porém, isso não aconteceu e ele não voltou nos braços do povo como almejava. Quanto ao setor agrário e seus problemas estruturais, Quadros estabeleceu "uma política de preços mínimos"; logo após, edificou "unidades móveis de crédito rural" mexendo, assim, na base da fixação dos preços para a produção.

João Goulart assumiu a presidência em 1961 representando esperança para a esquerda e a direita. Mas, sob "o selo de um governo popular, exigia-se que o governo tivesse uma atuação impopular" (MARINI, 2012, p. 100). Ele tentou voltar-se para a esquerda e, em 1964, pressionado por uma mobilização popular, que reuniu meio milhão de pessoas, intentou realizar reformas de base. Entretanto, a direita armou o golpe militar que o destituiu do poder, em 1964, e instaurou a ditadura que vigorou até 1985. Nas palavras de Castelo (2012), "instaurou-se a autocracia burguesa e consolidou-se o capitalismo financeiro no Brasil” (p. 620).

Os grupos progressistas - dos trabalhistas aos comunistas, dos reformistas aos revolucionários - que apoiavam em maior ou menor grau o nacional-desenvolvimentismo foram derrotados e massacrados por uma ditadura civil-militar de vinte anos, e o desenvolvimentismo tomou novos rumos sob o tacão de ferro dos militares, da tecnocracia estatal e da burguesia, hegemonizada pelos monopólios internacionais. $\mathrm{O}$ milagre veio, o bolo cresceu, mas a dependência e o subdesenvolvimento persistiram, e as desigualdades socioeconômicas aumentaram, com imensas perdas para a classe trabalhadora (Id., p. $620 / 621)$ 
Segundo Castelo (2012), os clássicos do desenvolvimentismo no país, como Celso Furtado, Florestan Fernandes e Caio Prado, partiram da realidade social e suas várias ligações com sua estrutura; tinham "uma perspectiva multidisciplinar, explicitando suas concepções de mundo e seus propósitos político-ideológicos” (p. 621). Sampaio Jr. (2012), por sua vez, explicita que a análise dos desenvolvimentistas ressaltava a necessidade de mudanças na estrutura, que acometessem as raízes do subdesenvolvimento. Acreditavam que os entraves estruturais construídos historicamente poderiam ser ultrapassados pela escolha política do país e, assim, implantado um desenvolvimento capitalista nacional.

O desenvolvimentismo foi, portanto, uma arma ideológica das forças econômicas e sociais que, no momento decisivo de cristalização das estruturas da economia e da sociedade burguesa, se batiam pela utopia de um capitalismo domesticado, subordinado aos desígnios da sociedade nacional (p.674)

Além disso, considerava-se que a superação da situação em que o capitalismo se encontrava, no país, não se daria como parte de um processo de desenvolvimento capitalista; fazia-se necessário a intervenção do homem, para o rompimento dessa situação de dependência e subdesenvolvimento, fazendo-se imprescindíveis mudanças estruturais em diversas dimensões, o que provocaria a melhoria real de vida da população. Para tanto, contava-se com a participação das burguesias nacionais.

Sem a presenças de burguesias nacionais capazes de enfrentar os interesses externos e internos comprometidos com a reprodução da situação de dependência e subdesenvolvimento, a concepção 'desenvolvimentista' pareceria, pois não teria como se converter em força real. A sorte do 'desenvolvimentismo, confundia-se assim, com o próprio destino de formação da sociedade nacional. (Id. p.675).

Contudo, como elucida o autor, o golpe de 1964 e a chegada dos militares ao poder, trucidou o sonho nacional-desenvolvimentista, de feição populista, pois materializou-se um capitalismo dependente com apoio estadunidense; quebrou-se o processo de implementação de reformas estruturais e implementou-se de vez a articulação “dependência e segregação social" (p.676). Anulou-se, além disso, as contradições imperialismo-desenvolvimentismo e pobreza-desenvolvimento capitalista autodeterminado. E diminuiu o que seria o desenvolvimento, passando a ser "simples processo de industrialização e modernização, deixando de lado a questão da autonomia nacional e o problema da integração social” (Id. p.677). 


\section{Crise capitalista}

Para compreender a crise contemporânea, faz-se necessário lembrar primeiramente, que, faz parte do sistema capitalista ter crises. Na realidade, anteriormente ao capitalismo, já existiam crises, contudo, o caráter das mesmas era diferente, no dizer de Mandel (1990); eram "quase todas resultantes da penúria material em decorrência da subprodução de valores de uso" (p. 210). Ou seja, o problema maior era a escassez de produtos. Já no sistema capitalista, o problema é justamente o contrário, “é porque há a impossibilidade de venda de mercadoria a preços que garantam o lucro médio- isto é, porque há muitas mercadorias, ou superprodução,- que a vida econômica, se desorganiza" (p. 210). As causas das crises capitalistas segundo o autor, estariam, então, na super acumulação de capitais; no sub consumo das massas; na anarquia da produção e desproporcionalidade da mesma; e na queda da taxa de lucros. Teria como função principal, "constituir o mecanismo através do qual a lei do valor se impuzesse" (p. 212). Assim sendo, as crises no sistema capitalista são fruto da superprodução de mercadorias, que impedem o crescimento da taxa de lucros, já que não se verifica um equilíbrio entre produção e consumo e as mercadorias não viram dinheiro para voltarem ao processo de acumulação de capital. Contudo, o capital se utiliza das crises para encontrar saídas dos impasses cíclicos que lhes são intrínsecos e progredir.

Em todos os âmbitos desdobrados pelo movimento do capital- seja na circulação ou na produção, seja no conflito com o trabalho ou na concorrência entre os capitalistas-, a autonegação do sistema aparece de diferentes formas, que se hierarquizam e se solidarizam distintamente em cada caso real. Mas sempre o excesso, a desmedida, o monstruoso é que atuam nesses âmbitos e na sua articulação. (GRESPAN, 2009, p.44)

Kondratiev foi o precursor dos estudos dos ciclos inerentes à economia capitalista. Neto (2009), ressalta que Kondratiev em sua análise afirma a existência de ondas longas entre ascensão e declínio, que ocorrem em média por volta de 50 anos; essas ondas tinham relação com o tempo de amadurecimento dos grandes investimentos em maquinário. Porém, para Trotsky, ainda segundo Neto (2009), esses períodos mais longos estariam ligados a fatores externos conexos à luta de classe e à expansão/evolução tecnológica, sem fixação de tempo exata. Posteriormente, Mandel, que, ainda segundo Neto, teria feito a junção entre a teoria de Kondratiev e Trotsky, chegando a concluir que: 
um deles (Trotsky) teria razão na passagem de uma fase descendente da onda longa para uma ascendente (por fatores extraeconômicos), enquanto outro (Kondratiev) teria razão na passagem de uma ascendente para uma descendente (por fatores puramente econômicos) (NETO, 2009, p. 102)

Contudo, as fases de boom, segundo Mandel (1990), começaram a ficar menores a partir dos anos de 1970. Isso porque, houve um "esgotamento da onda longa expansiva", segundo o autor, no mesmo passo em que ocorreu o contrário com as fases de estagnação e recessão, que começaram a se prolongar. Ou seja, apesar de o capitalismo ter se reestruturado e utilizado políticas expansivas e anticíclicas, no segundo pós-guerra ${ }^{5}$, isso não foi suficiente para resolver "nenhuma das contradições internas fundamentais do modo de produção capitalista" (MANDEL, 1982, p. 332). Logo, uma retomada expansiva nessa lógica está fora de cogitação; assim, estamos, correntemente, vivenciando uma onda longa de estagnação/recessão.

Essa percepção de Mandel, é coincidente com o argumento de István Mészáros (2011), o qual afirma que estamos vivenciando uma crise estrutural do capital, e não mais conjuntural ou cíclica, que "não pode pôr em risco a sobrevivência contínua da estrutura global” (p. 797). Uma crise estrutural (duradoura) e sistêmica (total), que "põe em questão a própria existência do complexo global envolvido, postulando sua transcendência e sua substituição por algum complexo alternativo" (p. 797). E, assim, essa crise, não está interligada "aos limites imediatos, mas aos limites últimos de uma estrutura global" (IDEM, p. 797). Para Castelo, esse fato é

resultado conjunto de uma crise de hegemonia com uma crise de super produção e de queda da taxa de lucro. Seu início decorreu dos movimentos de 1968 e disputas no âmbito da geopolítica de força do Terceiro Mundo para romper com o imperialismo. Esse foi, portanto, o estopim da crise, que não teria se tornado estrutural e prolongada se não houvesse também a crise econômica na primeira metade da década de 1970, que foi o combustível necessário para manter acessa a chama que incendiou os campos, como diz liricamente Tariq Ali. Com a confluência dessas duas tensões, a crise capitalista dos anos 1970 se tornou orgânica, dissolvendo o bloco histórico fordista-keynesiano. (CASTELO, 2013, p. 185)

\footnotetext{
${ }^{5}$ Sobre esse período Harvey (2012b) afirma que: como “o longo período de expansão do pós-guerra que se estendeu de 1945-1973, teve como base um conjunto de práticas de controle do trabalho, tecnologias, hábitos de consumo e configuração de poder político e econômico, esse conjunto pode com razão ser chamado de fordista-keynesiano. Com o colapso desse sistema a partir de 1973 iniciou um período de rápida mudança de fluidez e de incerteza" (p. 119)
} 
Ainda segundo Mészáros (2011), a severidade dessa crise é ressaltada pela impossibilidade de se intervir em suas causas, ficando-se somente no plano dos efeitos. E assim, o caminho provável para o seu andamento, não seria outro senão o seu aprofundamento, isto é: “continuarmos afundando, cada vez mais, na crise estrutural, mesmo que ocorram alguns sucessos conjunturais, como aqueles resultantes de uma relativa 'reversão positiva', no devido tempo, de determinantes meramente cíclicos da crise atual do capital (p. 810).

Tal crise eclode em 2008-2009 deixando paralitica a acumulação de capital. No que tange ao seu movimento Sampaio Jr. (2009) chama a atenção para o fato de ela deixar

patente a presença de uma gigantesca crise de superprodução. Puxada por uma drástica contração da indústria, entre outubro de 2008 e março de 2009 a economia mundial sofreu uma diminuição superior a $6 \%$ em relação a igual período do ano anterior. Nesse intervalo, o comércio mundial registrou uma diminuição de quase um terço, num movimento sem precedentes que atingiu todas as regiões do mundo. Os efeitos da crise sobre os trabalhadores foram devastadores (...) o número de desempregados aumentou em quase nove milhões e que mais de 100 milhões de pessoas passaram a integrar o número de trabalhadores pobres ( p.9-10).

Assim, apesar dos esforços para camuflar a real gravidade dessa crise e tentar uma possível recuperação ligeira, é evidente o seu peso, conforme Sampaio Jr. (2009), que também admite que ela englobou o mundo inteiro, mesmo que de maneiras distintas. As economias mais desenvolvidas foram atingidas mais intensamente; contudo, ela também chegou à periferia, onde as economias mais atingidas foram as da Europa Oriental e Sudeste Asiático, que estavam em um nível alto de interação econômica com países desenvolvidos. A América Latina, em geral passou pelo primeiro movimento da crise sem maiores desestabilizações. Mas, houve, nesse contexto, “expressivas baixas nas bolsas de valores, fortes desvalorizações das moedas nacionais, quedas violentas nas exportações e redução abrupta dos investimentos privados" (Idem, p. 12)

A estratégia escolhida para combater essa crise, segundo Sampaio Jr. (2009), foram as mesmas de outrora, utilizadas para conter as crises cíclicas, ilusórias, que agiam sobre os efeitos e não buscavam de fato soluções que possibilitassem o retorno do processo de acumulação. Dentre essas estratégias estão: “a diminuição da taxa de juros, a ampliação moderada do gasto público e a criação de uma série de isenções físcais para incentivar o aumento do consumo familiar e a retomada dos investimentos privados" (p. 15). Ou seja, houve uma mera administração da crise e não o seu efetivo enfrentamento. 
Dessa forma, como expõe o referido autor, a intervenção estatal serviu para impedir a falência do sistema financeiro internacional, mas, nada que pudesse ser considerado consistente num período maior de tempo, nada que chegasse até a raiz da crise. Inclusive, acrescenta que, a criação do Grupo dos 20 (G20) faz parte dessas medidas, donde o avanço está na busca, informalmente, de saídas da crise, por meio do debate de ideias, haja vista "a precariedade dos mecanismos existentes de coordenação internacional da política econômica" (p. 19). Vale ressaltar, ainda, que a entrada dos BRICS no Grupo dos 20, foi estratégica, na forma de prevenção no momento de crise, que tinha por trás a preocupação com "o aparecimento de qualquer tipo de iniciativa dissidente que pudesse representar um fator adicional de desestabilização da economia mundial (p. 19).

É importante ressaltar, conforme Fontes (2009), que a inserção brasileira no mundo como uma nação imperialista subalterna, tem prejudicado as poucas conquistas sociais internas, apesar de suavizar momentaneamente alguns sofrimentos nacionais. "A gigantesca extração de mais-valor extorquida se torna a cada dia mais invisível aos próprios trabalhadores" (p. 71).

Quanto à repercussão e às implicações da crise no Brasil, Sampaio Jr. (2011), assinala que, no primeiro movimento, o país "surfou na onda especulativa", fato viabilizado pela migração de capitais excedentes dos países centrais; com isso, houve um estímulo ao crescimento nas economias emergentes, possibilitando "abundância de liquidez no mercado financeiro internacional, grande afluxo de investimentos diretos e o boom nos preços das commodities" (IDEM, p. 86)

Entretanto, no segundo momento, de outubro de 2008 a março de 2009, Sampaio Jr. (2011), afirma que as implicações foram mais aturadas, porém, por volta de abril em diante a economia brasileira começou a se restaurar novamente, haja vista "o retorno dos capitais internacionais, a elevação dos preços das commodities e dos ativos financeiros, a retomada do comércio internacional " (p. 87), ao mesmo tempo em que contritas estavam as economias mundiais.

O terceiro momento da crise, foi marcada pela administração dos efeitos críticos, segundo o referido autor, pois não houve, como já indicado, um ataque sobre suas causas da crise, sendo os Estados Unidos à um exemplo dessa estratégia. Esse momento foi intitulado como sendo de metástase. O Brasil seguiu rumo a uma reversão neocolonial, ressalta o autor. Assim, 
por mais paradoxal que possa parecer, as condições que impulsionam o crescimento da economia brasileira- a abundância de divisas- trazem inscritas contradições que aumentam perigosamente a vulnerabilidade do país a crises de estrangulamento cambial. A absoluta subordinação do Estado brasileiro aos interesses dos rentistas - externos e internos- e do grande capital - nacional e internacional- compromete a política econômica ainda mais com medidas que implicam expansão perversa da dívida pública (...). Nessas circunstâncias, mesmo crescendo, a fragilidade fiscal do Estado brasileiro aumenta o risco de uma grave crise financeira torna-se cada vez maior (SAMPAIO Jr., 2011, p. 95).

\section{Liberalismo/ neoliberalismo}

Houve no mundo contemporâneo, a partir dos anos de 1970, o ressurgimento dos pressupostos do liberalismo, intitulado no momento como neoliberalismo, que se propagou em uma conjuntura história completamente diversa de suas origens. E esse ressurgimento veio como resposta e tentativa de sanar a crise dos anos de 1970 que, como já mencionado, revela a tendência estrutural. Assim, para se entender o neoliberalismo faz-se necessária uma remissão ao liberalismo clássico.

\section{Liberalismo clássico}

O liberalismo teve vários significados, valores, ideais e até mesmo direções no decorrer da história. Remonta, inclusive, à influência antiga de ideias e teorias de séculos atrás, como as de Aristóteles, Platão, Cícero, dentre outros. Segundo Seabright (apud HEYWOOD, 2010), a sua procedência, presumivelmente, advém das primeiras sociedades agrárias (comunidades sedentárias), visto que se iniciou a partir, de então, a comercialização e o convívio com pessoas desconhecidas. Mas, o uso do termo liberal, segundo Heywood (2010), é datado do século XIV. Fazia-se alusão a quem era livre, ou seja, não era servo e também não era escravo. Ressalta-se que a expressão "liberalismo" enquanto filiação política, só foi utilizada nos primórdios do século XIX, na Espanha de 1812; e já nos anos de 1840, com a extensão do continente europeu, era identificado como um "conjunto específico de ideias políticas" (p.37), sob o qual formou-se o primeiro governo inglês, expressamente liberal, com a chegada de Gladstone como primeiroministro em 1868.

Contudo, o liberalismo como ideologia mais consolidada, adveio da queda do feudalismo europeu e a ascensão da sociedade de mercado. Os liberais buscavam romper com a aristocracia, o clero e o Estado aboslutista, assumindo um viés altamente transformador, naquele momento. Seus adeptos, representantes da burguesia nascente, 
desafiavam o poder absoluto da monarquia, que estaria ancorado na doutrina do "direito divino dos reis". No lugar do absolutismo, eles defendiam um governo constitucional, e mais tarde o direito representativo. Também criticavam os privilégios políticos e econômicos da aristocracia rural e a injustiça de um sistema feudal em que a posição social era determinada pelo "acidente do nascimento". Além disso, questionavam a autoridade da Igreja e apoiavam os movimentos que lutavam pela liberdade de consciência religiosa. (HEYWOOD, 2010, p. 38)

Todavia, a partir do momento em que o liberalismo foi ganhando espaço, foi perdendo o seu caráter revolucionário, e assim, “tornava-se cada vez mais conservador, representando mais a manutenção das instituições existentes- basicamente liberais - do que a mudança e a reforma" (Idem, 2010, p. 39). O liberalismo, segundo Montaño (2011), é uma tradição diversa no entanto, possui, como possibilitador de unidade, dois pontos: “ a ordem burguesa e a garantia de liberdades" (p. 49). Marx e Engels (2006), discorrem, brilhantemente, sobre esse momento histórico, nos seguintes termos:

Onde quer que tenha assumido o poder, a burguesia pôs fim a todas as relações feudais, patriarcais e idílicas. Destruiu impiedosamente os vários laços feudais que ligavam o homem a seus "superiores naturais", deixando como única forma de relação entre os homens o laço do frio interesse, o insensível "pagamento à vista". Afogou os êxtases sagrados do fervor religioso, do entusiasmo cavalheiresco e do sentimentalismo pequeno-burguês nas gélidas águas do cálculo egoísta. Fez da dignidade pessoal um simples valor de troca e, em nome das numerosas liberdades conquistadas, estabeleceu a implacável liberdade do comércio. Em suma, substituiu a exploração, encoberta pelas ilusões religiosas e políticas, pela exploração aberta, única, direta e brutal. (p. 35/36)

O liberalismo apesar das suas divergências, tem como face comum a crença no individualismo egoísta; acredita que os indivíduos são autossuficientes, como característica própria e possuidores de autonomia; defende a liberdade negativa, ou seja, a liberdade no sentido de não haver interferências externas à vida privada; o Estado deve interferir minimamente, existe propensão ao equilíbrio entre interesses concorrentes. Para Heywood (2010), “o tema central da ideologia liberal é o compromisso com o indivíduo e o desejo de construir uma sociedade em que as pessoas possam se realizar e defender seus interesses pessoais" (p. 37). O Estado deve ser "mínimo [e sua] função se restringe à manutenção da ordem interna e da segurança pessoal" (37). No entender de Bobbio (2013), o liberalismo é: 
uma teoria dos limites do poder do Estado, derivados da pressuposição de direitos ou interesses do indivíduo, precedentes a formação do poder político, entre os quais não se pode estar ausente o poder da propriedade individual. [...] o Estado é tão mais liberal quanto mais são reduzidos os poderes, e, correlativamente quanto mais ampla é a esfera da liberdade negativa" (p. 89)

Dentre os princípios do liberalismo tem-se a primazia do indivíduo. Segundo Heywood (2010), houve aí um rompimento com período medieval, já que outrora não se entendia o indivíduo como um ente único, possuidor de identidade pessoal e interesse próprio. As explicações para a compreensão da realidade começaram a se transformar e perdiam cada vez mais espaço as explicações advindas da religião; em compensação, ganhava corpo as explicações científicas e racionais, abarcadas pelo ponto de vista do indivíduo. Kant, por exemplo, tinha o interesse na liberdade moral dos indivíduos e os entendia como: “ 'fins em si mesmos' e não apenas como meios de alcançar os objetivos dos outros” (p. 41). Apesar das divergências e discrepâncias entre os entendimentos sobre esses indivíduos, os liberais tinham em mente a vontade de " criar uma sociedade em que cada indivíduo seja capaz de se desenvolver e prosperar até alcançar todo o seu potencial” (Idem, p. 42).

Ainda segundo Heywood (2010), essa supervaloração do indivíduo fortalece a relação com a liberdade individual, a qual é entendida como o valor político de suma importância, que inclusive configura o eixo que a interliga a teoria. Mas, a mesma foi entendida de diversas formas: por uns, como "direito natural" e, por outros, como exclusiva condição que leva à efetivação das potencialidades individuais; outros ainda, não a compreendiam como direito absoluto; enfim, não havia um consenso sobre a acepção do que era ser livre. A crença nessa liberdade liberal sofreu influência do iluminismo e sua suposta defesa da razão, que era entendida como possibilitador do homem de alcançar " a capacidade de assumir a responsabilidade pela própria vida e decidir sobre o próprio destino" (p. 45)

Outro princípio que os liberais defendem é o da igualdade de oportunidades, ou seja, todos nascem iguais e possuem direito à mesma oportunidade, cabendo a cada um aproveitá-la a ou não; e assim justificam sua defesa da meritocracia. Dessa forma, para eles, é "correto recompensar o mérito, a habilidade e a disposição para trabalhar [...] os indivíduos terão incentivo para realizar seu potencial e desenvolver seu talento inato" (HEYWOOD, 2010, p. 46/47). 
Os liberais acreditavam, ademais, em uma sociedade equilibrada, guiada por uma mesma espécie de mão invisível. Entretanto, temiam que alguns indivíduos desrespeitassem as liberdades individuais e, por isso, justificaram a necessidade de um Estado, que, porém, intervisse minimamente. Nas palavras de Bobbio (2013), “o Estado Liberal é justificado como o resultado de um acordo entre indivíduos inicialmente livres que convencionam estabelecer os vínculos estritamente necessários a uma convivência pacífica e duradoura" (p. 14). O Estado, para os liberais, no que tange a sua função, "se restringe à manutenção da ordem interna e da segurança pessoal" (HEYWOOD, 2010, p. $37)$.

A concepção de Estado dos liberais clássicos teve a sua edificação no período histórico de transição do feudalismo para o capitalismo. Entre os séculos XVII e final do XVIII, marcaram o pensamento moderno as teorias dos "direitos naturais" ou “jusnaturalistas"; seus principai formuladores ${ }^{6}$ foram John Locke, Thomas Hobbes, JeanJacques Rousseau e Thomas Jefferson (EUA). Nessa doutrina o ser humano:

indiscriminadamente, tem por natureza, e portanto, independentemente de sua própria vontade, e menos ainda da vontade de alguns poucos ou de apenas um, certos direitos fundamentais, como o direito à vida, a liberdade, a segurança, a felicidade- direitos esses que o Estado, ou mais concretamente aqueles que num determinado momento histórico detêm o poder legítimo de exercer a força para obter obediência a seus comandos devem respeitar, e portanto, não invadir, e ao mesmo tempo proteger contra toda possível invasão por parte dos outros (BOBBIO, 2013, p.11).

Assim, é de fundamental importância entender que, pela ótica liberal, a criação do Estado foi justificada como sendo fruto de um contrato social necessário, devido à natureza humana, sendo este argumento construído por meio de uma ficção histórica sobre o "estado de natureza". Segundo Montaño (2011), a maior contribuição dos contratualistas liberais à teoria do Estado, foi o entendimento de que o ser humano é um "ser natural, racional e individualizado, que age movido por paixões e interesses" (p.23). No que diz respeito diretamente ao Estado, atitudes liberais:

em primeiro lugar, sugere que, em certo sentido, a autoridade política vem "de baixo". O Estado é criado por indivíduos e para indivíduos; existe para servir as suas necessidades e interesses. O governo surge do acordo, ou consentimento, dos governados. Isso implica que os cidadãos não têm obrigações de obedecer a todas as leis ou de aceitar

\footnotetext{
${ }^{6}$ Vale ressaltar que havia também algumas divergências quanto à defesa dos autores contratualistas como: a propriedade era entendida por Locke como direito natural, já para Thomas Jefferson não; para Hobbes o governo deveria ser absoluto, mas, para Locke, limitado.
} 
qualquer forma de governo. [...] Em segundo lugar, a teoria do contrato social retrata o Estado como um juiz ou árbitro neutro na sociedada (HEYWOOD, 2010, p. 49/50).

Outra teoria que auxiliou no desenvolvimento do liberalismo foi a fundada pelos Utilitaristas, cujos maiores nomes foram Jeremy Bentham, seu criador, e Stuart Mill. Segundo Bobbio (2013), utilitarismo e liberalismo estavam juntos, e foram de suma importância para a teoria do Estado liberal. Bentham discordava da ideia dos direitos naturais, propondo

que os indivíduos são motivados por interesses pessoais e que esses interesses podem ser definidos como desejo de prazer, ou felicidade, e o desejo de evitar a dor, ambos calculados na forma de utilidade. [...] acredita-se que cada indivíduo seja capaz de perceber o que é melhor para si. Uma autoridade paternal, como o Estado, não pode decidir por ele (HEYWOOD, 2010, p. 59).

Para defender e explicar a limitação do poder do Estado, Mill, baseado na liberdade negativa (de negar a intervenção do Estado na vida privada), construiu um princípio que consiste em colocar, segundo Bobbio (2013), restrições ao poder do Estado quanto a intervenções sobre a liberdade dos indivíduos e o âmbito em que os indivíduos/grupos ajam sem que ocorra interferência do Estado; donde, deve haver ajustamento entre o individual e o coletivo. Assim, tem-se como pressuposto ético que “cada um é o único guardião autêntico da própria saúde, tanto física quanto mental e espiritual” (MILL apud BOBBIO, 2013, p. 66).

Ainda existem dois pensadores que tiveram imensa contribuição no pensamento liberal. São eles: os economistas Adam Smith e David Ricardo, entre o final do século XVIII e início do XIX. Neles, verifica-se a presença da teoria utilitarista no raciocínio do homem econômico. Segundo Heywood (2010), Smith discordava do mercantilismo e sua arguição dele em defesa de um Estado que interferisse minimante na economia, pois considerava que a economia se desenvolve melhor sem interferência dos governos. Para ele, com a conquista da liberdade econômica poder-se-ia chegar à liberdade total. Assim, “embora cada indivíduo seja egoísta em termos materiais, a própria economia funciona de acordo com um conjunto de pressões impessoais - forças de mercado - que tendem naturalmente a promover a prosperidade econômica e o bem-estar" (p. 61). Segundo Siqueira (2012), Ricardo transportou as ideias de Smith para a esfera internacional. Seu argumento é de que, 
num sistema comercial perfeitamente livre, cada país naturalmente dedica seu capital e seu trabalho à atividade que lhe seja mais benéfica. Essa busca de vantagem individual está admiravelmente associada ao bem universal do conjunto dos países. Estimulando a dedicação ao trabalho, recompensando a engenhosidade e propiciando o uso mais eficaz das potencialidades proporcionadas pela natureza, distribui-se o trabalho de modo mais eficiente e mais econômico, enquanto pelo aumento geral de volume de produtos difunde-se o benefício de modo geral e une-se a sociedade universal de todas as nações do mundo civilizado por laços comuns de interesse e intercâmbio (RICARDO apud SIQUEIRA, 2012, p. 30).

De acordo com Heywood (2010), o apogeu das ideias de livre mercado ocorreu no século XIX, por meio da teoria do laissez-faire (“deixar agir”), que consistia na defesa extrema de que o Estado não deveria intervir na economia. Esse individualismo econômico tinha como base a convicção de que a procura incondicional pelo lucro favoreceria a todos. É importante ressaltar que ele " se opunham a todas as formas de legislação fabril, incluindo restrições ao emprego de crianças, limites às horas de trabalho e qualquer regulamentação de condições de trabalho" (Idem, p. 61). Além disso, a pobreza e a desigualdade social eram marcadas pela ideia de autossuficiência, de acordo com a qual "os indivíduos fazem o que querem, e o que podem, com a própria vida. Aqueles com capacidade e disposição prosperam, ao passo que os incompetentes ou preguiçosos não" (IDEM, p. 62).

Outro ideólogo liberal que deve ser mencionado foi Herbert Spencer. Segundo Heywood (2010), ao defender a doutrina do laissez-faire, Spencer somou essa doutrina à teoria da evolução das espécies do biólogo Charles Darwin, estendendo os limites das ciências biológicas para a teoria política e social. Criou, dessa feita, o darwinismo social, segundo o qual havia pessoas mais e menos aptas ao sucesso e as que fracassavam deveriam perecer. Para ele, portanto "as desigualdades de riqueza, posição social e poder político [eram], naturais e inevitáveis; [por isso], e o governo não [deveria] fazer nenhum tipo de intervenção" (Idem, p. 63)

Perante o exposto importa ressaltar que, nesse mesmo período histórico, houve outras análises, muito mais fecundas, das quais este estudo compartilha, mas que não serão objeto direto de análise. Contudo, cabe indicar, mesmo que de forma sucinta, as elucubrações de Marx, sobre a mesma matéria.

Primeiro, o capitalismo não é uma ordem natural, mas essencialmente constituída por meio de ações históricas; segundo, o mercado não é um espaço social de oportunidade, liberdade e igualdade dos agentes econômicos, mas uma ordem opressora, dominadora, alienante, exploradora. O capitalismo é definido a partir das relações sociais de 
propriedade e produção específicas que geram um modo particular de exploração do trabalho pela classe burguesa, que, por sua vez, gera uma lei geral de acumulação nunca vista na história humana [...] Em suma, o revolucionário germânico demonstra que a igualdade e a liberdade da grande maioria dos seres humanos na ordem capitalista, marcada por profundas desigualdades entre classes sociais, é puramente formal: os trabalhadores não possuem os meios necessários ao exercício efetivo das liberdades, nem ao pleno usufruto da riqueza socialmente produzida por eles próprios" (CASTELO, 2013, p. 17-18).

\section{Neoliberalismo}

As ideias neoliberais só começaram a ganhar notoriedade com a crise do modelo econômico do segundo pós-guerra, nos anos 1970, quando a perda de hegemonia do regime de produção keynesiano-fordista - que previa a intervenção do Estado na economia e na sociedade - cedeu lugar ao modelo econômico monetarista, que privilegiava a ação livre do mercado. Em decorrência, a partir dos anos 1980, o neoliberalismo se firmou como o paradigma dominante cujas ideias consistiam em uma

teoria das práticas político-econômicas que propõe que o bem-estar humano pode ser mais bem promovido liberando as liberdades e capacidades empreendedoras individuais no âmbito de uma estrutura institucional caracterizada por sólidos direitos a propriedade privada, livres mercados e livre comércio. O papel do Estado é criar e preservar uma estrutura institucional apropriada a essa prática (HARVEY, 2012, p. 12).

O Estado, na teoria neoliberal, apesar de ser minimizado, tem, na verdade, papel fundamental, o que indica uma prática não condizente com a pregação de seus mentores. "Há na posição neoliberal contradições suficientes para tornar as práticas neoliberais em desenvolvimento irreconhecíveis diante da aparente pureza da doutrina" (HARVEY, Id. p. 30).

O Estado neoliberal possui a tarefa de:

criar e preservar uma estrutura institucional apropriada, [...] garantir direitos de propriedade individuais e para assegurar, se necessário pela força, o funcionamento apropriado dos mercados, além disso se não existirem mercados estes devem ser criados, se necessário pela ação do Estado. Mas o Estado não deve se aventurar para além dessas tarefas. As intervenções do Estado nos mercados (uma vez criados) devem ser mantidas num nível mínimo, porque, de acordo com a teoria, o Estado possivelmente não possui informações suficientes para entender devidamente os sinais do mercado (preços) e porque poderosos grupos de interesse vão inevitavelmente distorcer e viciar as intervenções do Estado (particularmente nas democracias) em seu próprio beneficio (HARVEY, 2012, p.12). 
Harvey (2012) informa que existem conflitos na teoria geral do Estado neoliberal, a saber: do poder de monopólio, fracassos de mercado, pressuposto de perfeito acesso a informação, igualdade de condições na competição e problemas políticos. E, na prática, o autor ressalta a dificuldade de descrever esse Estado, por não ser compatível com a teoria e que, na realidade, tem havido adaptações que se modificam a depender da época e do lugar. Contudo, mesmo assim, "há dois campos em particular em que o ímpeto de restauração do poder de classe distorce e, em alguns aspectos, até reverte a teoria neoliberal na prática” (p. 80/81). São eles:

1) o primeiro, "vem da necessidade de criar um 'clima de negócios ou de investimentos favoráveis' para empreendimentos capitalistas" (p.81) e

2)

o segundo, "vem do fato de que, em caso de conflito, os Estados neoliberais tipicamente favorecem a integridade do sistema financeiro e a solvência das instituições financeiras e não o bemestar da população ou a qualidade ambiental” (p.81).

Pode-se a isso somar "problemas friccionais de transição que refletem as diferentes formas de Estado que havia antes da virada neoliberal" (p.81).

A neoliberalização ocorreu no mundo de forma desigual. Foi um processo complexo que teve várias determinações. Os seus principais defensores em âmbito mundial, tanto em relação à teoria quanto à prática, são os denominados por Ianni (2011), de "guardiões" e/ou "santíssima trindade" ou troika, composta pelo Fundo Monetário Internacional, Banco Internacional de Reconstrução e Desenvolvimento e Organização Mundial do Comércio.

Harvey (2012) afirma que a entrada dos países no processo de neoliberalização se deu em grande maioria de forma parcial: "a introdução de maior flexibilidade nos mercados de trabalho aqui, uma desregulamentação das operações financeiras e a adoção do monetarismo ali, certas privatizações de setores nas mãos do Estado acolá” (p. 98).

O autor assinala que o seu desenvolvimento geográfico foi diferenciado entre as nações, sendo 
regionais e mesmo metropolitanos, quanto o foi da imposição por algum poder hegemônico externo como os Estados Unidos (Id. p.125).

Outros fatores também devem ser levados em conta como nessa diferenciação:

alguma combinação do poder das ideias neoliberais (que se sustentaram particularmente grande nos casos da Grã-Bretanha e do Chile), da necessidade de reagir a crises financeiras de maneiras diversas (como no México e na Coréia do Sul) e de uma abordagem mais pragmática de reforma do aparato de Estado (caso da França e da China) a im de melhorar a sua posição competitiva no mercado global (Id., p. 125).

Para se ter uma noção mais abrangente desse desenvolvimento geograficamente assimétrico, tem-se que ir além e acrescentar a percepção da "interação das dinâmicas internas e externas" (Id. p. 126) do processo, pois "é improvável que mesmo o mais draconiano programa de reestruturação do FMI possa ir adiante sem ao menos algum apoio interno da parte de alguém” (Id., p. 127).

A neoliberalização brasileira foi tardia, se comparada com a dos demais países latino-americanos. No governo de José Sarney (1985-1990), durante a transição do regime ditatorial para a redemocratização do país, conviviam políticas do Estado Desenvolvimentista e do regime de Redemocratização. Como afirma Soares (2009), existia no momento de transição da ditadura para a democracia uma "hegemonia conservadora", mas também forças sociais, como as dos movimentos sociais bem atuantes e várias propostas de gestão pública dentro do próprio Estado. Sarney não conseguiu se legitimar dentro daquela realidade, "uma sociedade carente de consensos e hegemonias, sem parâmetros de ação coletiva, sofrendo os impactos de uma economia destruída pela hiperinflação" (p.38), o que acabou por gerar pressão por mudanças. Isso porque, de acordo com Sader (2013), o governo havia fracassado, ao conviver com o antigo e o novo regime, não conseguindo, portanto, "que a democratização política se desdobrasse em democratização econômica, social e cultural” (p.137).

Com o término do governo Sarney, instituído por meio de eleição indireta, houve eleição direta, em 1989, com a vitória de Fernando Collor de Mello. O novo presidente conseguiu votos, segundo Soares (2009), da direita política e de vários setores da população que acreditaram na sua proposta de "reformulação profunda". No entanto, o que o governo Collor de Mello fez, foi aderir ao programa neoliberal, para surpresa de muitos. Pereira (2008), afirma ter existido uma enorme desconexão entre a sua proposta eleitoral e a sua prática: fez "uso de discurso de matiz socialdemocrata, mas logo se 
mostrou afinado com ideário neoliberal e a ele submisso" (p.161). Eis algumas de suas principais propostas no campo econômico e posteriormente social:

no campo econômico: a) retomada, a curto prazo, do crescimento, com simultâneo combate à inflação e ao desequilíbrio fiscal; b) modernização econômica, a longo prazo, com base na desregulamentação do mercado. No campo social: a) ressarcimento da dívida social, via crescimento econômico; b) melhoria da distribuição de renda, por meio da criação de emprego e do aumento dos salários reais; c) manutenção das políticas sociais compensatórias, mas com redefinição de suas prioridades e formas de financiamento; d) descentralização da gestão das políticas sociais; e) reforço do Estado como condição para requalificação de instrumentos e quadros de gestão dos sistemas sociais do governo e para o financiamento das políticas sociais (PEREIRA, Id, pp. 161/162).

E eis também algumas de suas principais práticas adotadas nos mesmos campos (econômico e social):

No campo econômico: a) mudança do nome da moeda, que voltou a ser cruzeiro; b) redução da liquidez por meio de sequestro e congelamento dos ativos financeiros; c) desindexação geral, especialmente entre preços e salários; d) achatamento salarial; privatizações de empresas estatais; f) abertura da economia ao capital; g) suspensão dos incentivos fiscais, com exceção dos concedidos à Zona Franca de Manaus; h) implantação de políticas fiscais e monetárias restritivas; No campo social: a) preservação e aprofundamento da fragmentação e descoordenação institucional. Ao contrário da área econômica, a social foi desmantelada tanto do ponto de vista da sua organização quanto da sua competência; b) demissão de 360 mil funcionários públicos em conformidade com as metas da reforma administrativa, integrante de uma pretensa reforma do Estado; c) oposição sistemática à consumação dos novos direitos constitucionais; d) resgate do assistencialismo, do clientelismo e do populismo; e) rejeição explícita do padrão da seguridade social previsto na Constituição Federal de 1988; f) seletivização e focalização das políticas sociais, a partir de 1991 (Id., pp.162/163).

Para conseguir seus objetivos, segundo a autora, Collor usou medidas provisórias, utilizando-se da justificativa de um quadro inflacionário e de aumento das dificuldades fiscais; e até tentou apressar a revisão da Constituição, que estava prevista para o ano de 1993, com a alegação de a mesma induzir medidas inflacionárias.

Segundo Sader (2013), o processo de transição democrática não se efetivou no referido governo, devido às escolhas do mesmo. Ele não foi capaz de democratizar "o sistema bancário, nem os meios de comunicação, nem a propriedade da terra, nem as grandes estruturas industriais e comerciais" (p. 137). Collor de Mello, que sucedeu a 
Sarney em março 1990, foi destituído da presidência em 1992, assumindo em seu lugar o vice Itamar Franco, em 1993. De acordo com Pereira (2008), o legado deixado por Collor contemplava: estagnação e desmantelamento do que se havia construído no âmbito da proteção social, ao qual foi adicionado um projeto político inconsistente no curto governo Itamar.

Entretanto, deve-se considerar alguns dos feitos de Itamar Franco, ressaltados pela autora, em várias esferas: controle da inflação por meio do Plano Real; aprovação da Lei Orgânica da Assistência Social (LOAS); liberalização de recursos previdenciários represados pelo governo anterior. Com a aprovação da LOAS, houve a regulamentação do benefício constitucional de prestação continuada aos idosos e portadores de deficiência pobres, o BPC, que substituiu a Renda Mensal Vitalícia; esta, por sua vez, era mais abrangente em termos de público-alvo. Houve também, readmissão de alguns funcionários públicos demitidos pelo governo Collor, que o antecedeu, e a implantação do Plano de Combate à Fome e a Miséria pela Vida (PCFMV), liderado pelo sociólogo Hebert de Souza (o "Betinho").

Sucedendo Itamar Franco, foi eleito como mandatário da Presidência da República Fernando Henrique Cardoso (FHC), que governou por dois mandatos consecutivos: 1995-1999 e 1999-2002. Com o governo FHC concretiza-se a neoliberalização do Estado brasileiro, logicamente, com "resistências políticas e populares, protagonizadas por partidos de esquerda e movimentos sociais" (SADER, 2013, p.137). FHC, segundo Pereira (2008), teve como prioridades a garantia da manutenção da estabilidade macroeconômica (efetivada no governo que lhe antecedeu, mas, com seu controle) e reformas na Constituição Federal, conhecida como Constituição Cidadã. Em seu primeiro mandato, conforme a autora, FHC teve como meta de governo a "redução da participação do Estado nas atividades econômicas e a desregulamentação do mercado" (p. 167).

[Sua] proposta de desregulamentação da economia basicamente, defende a abolição da regulação do Estado sobre os preços da economia em geral e sobre as relações capital-trabalho. Essa regulação, considerada como geradora de 'distorções', passa a ser substituída pelo 'livre jogo do mercado', cujos mecanismos de regulação seriam automáticos, tecnicamente isentos, proporcionando assim uma distribuição de recursos mais racional. A retirada do Estado ou a sua renúncia como agente econômico produtivo e empresarial é outra das promessas integrantes do projeto. Daqui se derivam as propostas de privatização das empresas estatais, o que contribui para a redução (estratégica) do setor público, bem como o rearranjo de toda a máquina 
estatal, situado na proposta mais ampla de Reforma do Estado (SOARES, 2009, p. 39).

Obviamente, as metas do governo FHC não estavam de acordo com a Constituição Federal de 1988. Mas, segundo Pereira (2008), isso não significou para o referido governo, uma barreira para a consolidação de suas propostas. O mesmo conseguiu, inclusive, aprovar no Congresso Nacional projetos de reforma da referida Constituição. Ressalta-se que a gestão pública brasileira desse período, cristalizou um bloco hegemônico que não era homogêneo, visto existirem divergências em seu interior como a direção neoliberal seguida pelo governo: de um lado, havia a defesa radical/ fundamentalista baseada em Hayek, opção escolhida pelo governo; e, de outro lado, a postura menos agressiva, que considerava o social, baseada em Rawls. "Para ele, o mais importante era a rápida estabilização dos preços e a defesa do Plano Real, ainda que isso implicasse (como implicou) recessão e desemprego" (PEREIRA, Id. p.168/169).

Depois de sua reeleição, acrescenta Pereira (Id.), FHC continuou com sua política de estabilização; não foi construída uma agenda que fosse para além disso, resultando nos seguintes problemas / consequências em seu primeiro mandato: continuação da pobreza e do desemprego. O se que prevaleceu, nesse governo, foi um forte empenho em proteger o capital, diga-se de passagem, "à custa do trabalhador, seja rebaixando o [seu] poder de compra e de consumo, seja esvaziando direitos sociais que o protegiam da insegurança social e dos caprichos do Estado e do mercado" (Id. p. 176). Sader (2013), afirma ter se desenvolvido no Brasil da época a financeirização da economia e a precarização das relações de trabalho, "herança maldita" segundo o autor, com a qual iria se deparar o governo Lula. Portanto,

na época neoliberal, não há espaço para o aprofundamento dos direitos sociais, ainda que limitados, mas estamos diante da tentativa aberta infelizmente em grande parte bem sucedida - de eliminar tais direitos, de desconstruir e negar as reformas já conquistadas pelas classes subalternas (COUTINHO, 2008 p. 102).

\section{Política social - Assistência social}

Várias são as maneiras com que se entende e se faz análise das políticas sociais. Assim sendo, inicia-se a sua explicitação demarcando a apreensão da mesma por esta pesquisadora, já que esse procedimento guiará a forma como ela será abordada e analisada posteriormente. Demarca-se que a política social é histórica; complexa; contraditória; tem várias causas e funções; configurações; é resultado e parte do todo no qual está inserida 
e intimamente associada às esferas política, econômica, cultural da sociedade. Assim sendo, vai-se contra entende-la, nas palavras de Pereira (2008b), "como agregado de setores segmentados" (p. 15). Não é de forma alguma neutra; afinal, "seu debate encerra fortes tensões entre visões sociais de mundo diferentes" (BEHRING, 2009, p. 302).

A existência das políticas sociais é bastante antiga, segundo Pereira (2008b); está historicamente relacionada ao mesmo tempo à garantia de satisfação das necessidades sociais e ao imperativo do atendimento às necessidades de lucro do capital. Já nas sociedades divididas em classes pré-capitalistas - escravista e feudal - ela situa-se entre interesses distintos. Dessa forma, não é coerente e consistente uma visão evolucionista que aborda a política social como "continuum que começa com a caridade privada, passando pela beneficência e assistência, até terminar na política social como prática evoluída e estritamente associada ao Welfare State” (p. 28).

Do mesmo modo não se pode compreendê-la com base em uma visão marxista mecanicista que a percebe como funcional apenas à classe trabalhadora ou apenas à classe dirigente. Behring (2008) baseada nas críticas de Coimbra, reitera que as análises bipolares da política social levam a apenas duas hipóteses: do engodo e da conquista; a primeira é marcada pela visão economicista, na qual, seu uso se dá para cooptação da classe trabalhadora, funcional assim somente a acumulação; já a segunda é marcada pela visão politicista, na qual é resultado único da luta dos trabalhadores, vitória única sobre o Estado do capital. Ora, "sua constituição, como já enfatizado, decorre de conflitos de interesses e de constante relação (não necessariamente harmoniosa) entre Estado e sociedade" (PEREIRA, 2008b, p. 30). Disso decorre que,

\begin{abstract}
como todos os âmbitos da vida social, também a esfera das políticas sociais é determinada pela luta de classe. Através de suas lutas os trabalhadores postulam direitos sociais, que uma vez materializados, são sua indiscutível conquista; mas isso não anula a possibilidade de que, em determinadas conjunturas, a depender da correlação de forças, a burguesia use as políticas sociais para desmobilizar as classes trabalhadoras para tentar cooptá-las etc (...) Trata-se de uma contradição que se manifesta como um processo: processo no qual o capitalismo primeiro resiste, depois é forçado a recuar e fazer concessões, sem nunca deixar de tentar instrumentalizar a seu favor (ou mesmo suprimir, como atualmente ocorre) os direitos conquistados (COUTINHO, 2008, P. 65-68).
\end{abstract}

Neste momento da história das sociedades capitalistas, marcado por uma crise estrutural e sistêmica, a política social enfrenta vários obstáculos como estratégia de concretização de direitos sociais. E é nessa conjuntura que se insere a política social de 
assistência social brasileira, cujo passado histórico é caracterizado pela constituição do não direito, no Brasil. A partir da Constituição Federal de 1988 (CF 88), ela integrou o Sistema de Seguridade Social, composto também pelas políticas de saúde e previdência social. Segundo Boschetti (2012), essa Constituição é baseada no modelo Bismarkiano, no que tange à previdência, e no Beveridgiano no que tange à assistência e a saúde, sendo assim, “ depositário de expectativas de justiça social, pleno de uma simbologia redistributiva e sinalizador de cidadania" (VIANNA, 2012, p. 193).

Isso significa que a política de assistência social brasileira, além de dever constituir a rede de proteção social (...), deve funcionar como uma espécie de alavanca para incluir no circuito dos bens, serviços e direitos existentes na sociedade grupos sociais injustamente impedidos dessa participação (PEREIRA, 2012b, p. 230).

Contudo, a efetivação do atendimento às necessidades sociais da população previstas na $\mathrm{CF} / 88$, vem sendo contraditada pelo movimento de desresponsabilização do Estado referente a essa exigência. Seguindo tendência internacional predomina, no Brasil, a política social focalizada sobre as universais e maior atendimento às necessidades de lucro do capital em detrimento da satisfação das necessidades humanas. 


\section{CAPÍTULO 2}

\section{EMERGÊNCIA E TENDÊNCIAS DO “(NEO) \\ DESENVOLVIMENTISMO": UMA NEOLIBERALIZAÇÃO EM TEMPOS DE CRISE}

\subsection{Uma invenção latinoamericana}

O denominado neodesenvolvimentismo não é uma particularidade brasileira. A CEPAL, diante dos resultados antissociais da expansão do neoliberalismo na América Latina, analisou e propôs saídas reformistas à nova conjuntura, caracterizada por reformas do Estado, predomínio do mercado e da financeirização da economia. Foi nesse contexto que da visão Cepalina neoestruturalista foi construida. Segundo Siscú, Paula \& Michel (2005), essa visão configurava "uma estratégia de transformação produtiva com equidade social que permita compatibilizar um crescimento econômico sustentável com uma melhor distribuição de renda" (p. 1). Segundo Mota, Amaral \& Peruzzo (2012), a CEPAL passou a defender que não há o confronto entre dinamismo econômico X igualdade social. Assim, "as condições para que essa relação seja equilibrada dependerão das iniciativas que potencializem capacidades humanas e mobilizem energias a partir do Estado" (p. 157).

Dessa feita, a nova CEPAL, como passou a ser considerada, adotou uma visão intermediária no que tange a sua estratégia de desenvolvimento, ou uma "terceira via", nas palavras de Castelo (2010). De acordo com Carcanholo (2010), seus defensores afirmavam que a mesma possuía como característica a conotação de desenvolvimento a partir do mercado, na qual o Estado teria como função a regulação e o estímulo desse processo, estando a seu cargo promover e zelar pelo o crescimento/desenvolvimento dos países. Ou melhor, como pontua Saludjian (2010), o Estado serviria para "deixar claro as regras do jogo e permitir ao mercado agir de maneira eficaz" (p. 161). Assim,

os países periféricos em especial os da América Latina e Caribe, não deveriam retroceder nas reformas neoliberais, muito menos rechaçá-las. Pelo contrário, deveriam tomar as reformas como um dado e, a partir delas, buscar os elementos de política que conseguissem aumentar o grau de equidade social (CARCANOLHO, 2010, p. 137-138).

\subsubsection{Surgimento da ideia neodesenvolvimentista no Brasil}

No Brasil, o neodesenvolvimentismo como característica da contemporaneidade teve, conforme Prado \& Meirelles (2010), materialização no meio intelectual. Difundiu- 
se por meio do livro Novo-desenvolvimentismo: um projeto nacional de crescimento com equidade social?, datado 2005 e prefaciado por José Alencar (vice presidente da República do governo Lula). Esta publicação contém 17 contribuições que possuem, como base, uma suposta aliança de classes. São vários os assuntos abordados, indo da política externa à dívida pública.

De acordo com Siscú, Paula \& Michel (2005), a alternativa neodesenvolvimentista apresenta uma proposta de um Estado que regule a economia, sem conflitar com a economia de mercado e com um sistema financeiro não especulativo. Esse Estado, por ser forte, possibilitaria a execução de políticas expansionistas e defensivas, assim como medidas que minimizassem a volatilidade demasiada da taxa de cambio e possibilitasse o ateio as exportações. A política industrial seria incrementada e deveria servir para incitar a competitividade da indústria, enquanto o comércio exterior propiciaria à nação melhor inserção no mercado mundial. Além disso, haveria necessidade do país buscar o progresso técnico e aumento da produtividade, mantendo sempre um sentimento nacionalista, isto é, de defesa dos interesses nacionais. E no que tange ao social, deveria haver distribuição de renda e riqueza via crescimento econômico e políticas de inclusão social.

Segundo Castelo (2012), existem três principais correntes de pensamento que defendem essa noção de desenvolvimentismo. São elas:

a) macroeconomia estruturalista do desenvolvimento, assim intitulada por Bresser Pereira. Ela defende a prioridade do mercado com regulação do Estado sobre as falhas daquele, incluindo nesse rol as políticas cambiais e de juros;

2) pós-keynesianas, que se apoiam em um Estado que diminui as incertezas econômicas, tendo como norte as decisões de investimento no setor privado;

3) social-desenvolvimentista, que visa o consumo de massa para materialização do mercado interno. Nesta corrente, o Estado tem papel de suma importância, porque defende políticas de desenvolvimento como sendo superiores às macroeconômicas.

A primeira corrente, segundo Mattei (2013), está ligada à Fundação Getúlio Vargas (FGV) de São Paulo. Seus pesquisadores, em um primeiro momento, realizaram uma análise da política econômica brasileira após o plano real; posteriormente, analisaram a "burguesia nacional" e, num terceiro momento, dedicaram-se a analisar a taxa de juros e a dívida pública. Esse conjunto de análises subsidiou a edificação de 
estratégias de desenvolvimento para o país que compuseram a corrente denominada "macroeconomia estruturalista do desenvolvimento", para quem deve haver a combinação do

uso dos recursos disponíveis com as instituições existentes no sentido de promover uma concertação de interesse dos agentes socioeconômicos visando atingir o objetivo geral, ou seja, a melhoria do padrão de vida de toda a população (...). [Tal estrtégia] pressupõe Estado e mercado fortes. [...] Na essência, essa proposição teórica coloca a taxa de cambio no centro das preocupações sobre desenvolvimento, procurando explicar as relações existentes entre desenvolvimento econômico e taxa de cambio. (...). [E] está baseada na oportunidade de investimentos voltados para exportação e na oportunidade de comércio voltada para o mercado interno (MATTEI, 2013, p. 45/47).

A segunda corrente, conforme Mattei (idem), está ligada ao Instituto de Economia da UFRJ, mas também encontra apoio entre professores da UnB, UERJ e UFRGS. Para Mattei, essa corrente tem ganhado mais espaço a partir de 2002, e mais força a partir de 2008, em razão da crise contemporânea do capital que assola o mundo. Suas análises também partem da política econômica brasileira dos governos FHC, que, segundo seus pesquisadores, deixou o Brasil a mercê dos ditames neoliberais. Posteriormente, as análises enfocam o quadro de dificuldades socioeconômicas nacional, a partir de 2003, indo contra as primeiras escolhas, do novo governo, de continuidade da política econômica do governo anterior. Foram eles os criadores da publicação Novo Desenvolvimentismo: um projeto nacional de crescimento com equidade social, que cunhou o terno neo(novo) desenvolvimentismo. Segundo Mattei (idem), esta corrente seria essa uma junção da doutrina keynesiana e pós-keynesiana com as concepções da nova CEPAL. Seus defensores concordam com a primeira corrente, encabeçada por Bresser Pereira; contudo, procuram ir além das proposições macroeconômicas ao considerar outros aspectos que lhes parecem relevantes, tais como:

as relações entre esfera pública e privada; as relações entre economia e a vida social; e as relações entre as dimensões nacional e internacional, considerando-se que propostas específicas em diversas áreas faziam parte do conjunto da obra (p. 49)

Assim, o novo desenvolvimentismo proposto por esta corrente, visa

a construção de um "terceiro discurso" entre a ortodoxia neoliberal e o populismo, com o objetivo de implementar um conjunto de reformas das políticas macroeconômicas e das instituições, visando fortalecer tanto o Estado como o mercado e, com isso, tornar o país mais 
competitivo no cenário internacional. Trata-se, portanto, de um novo projeto que busca transformar o Brasil em um país desenvolvido no longo prazo (MATTEI, 2013, p. 49-50).

A terceira corrente, ainda na avaliação de Mattei (Idem), está ligada ao Instituto de Pesquisa Econômica Aplicada (IPEA), vinculado ao Ministério do Planejamento. Ela aparece de forma mais consistente nos anos de 2006 em diante, tendo como pesquisador mais representativo Marcio Pochmann, então presidente do referido Instittuto. Segundo Mattei, esta corrente parte da ideia de que o neoliberalismo não mais dirigia a nação, embora mantivesse algumas políticas econômicas. Isso porque, que o Estado brasileiro estaria no da atualidade, sendo ele o dirigente desse novo desenvolvimento. Os integrantes desta corrente fizeram várias pesquisas buscando contribuição para sua proposta de desenvolvimento, que tem os seguintes eixos:

1) inserção internacional soberana; 2) macroeconomia para o pleno emprego; 3 ) infraestrutura econômica, social e urbana; 4) estrutura tecnoprodutiva avançada e regionalmente articulada; 5) sustentabilidade ambiental; 6) proteção social, direitos e oportunidades; 7) fortalecimento do Estado, das instituições e da democracia (MATTEI, 2013, p. 50).

Estas foram as ideias-força que deram suporte a um ideário governamental construído, a partir de 2003, com a intenção de resgate do intervencionismo estatal ocorrido entre os anos 1930 e 1960, que caracterizou o período brasileiro conhecido como desenvolvimentismo. Só que os tempos mudaram e a tendência desenvolvimentista, regulada pelo Estado, perdeu substância a partir dos anos 1980, com a ascensão do neoliberalismo. É com base nessas circunstâncias que será discutida a intenção neodesenvolvimentista dos governos Lula da Silva e Dilma Roussef, do Partido dos Trabalhadores.

\subsection{O Brasil " (neo)desenvolvimentista": utopia ou realidade?}

No Brasil contemporâneo, é recorrente o debate a respeito da existência ou não de uma experiência neodesenvolvimentista. Dela têm se ocupado vários setores intelectuais e políticos, dada a sua força ideológica e aparente existência. Assim, enquanto uns se ocupam em negá-la, outros alegam, inclusive, que, com ela, se vivencia um período pós-neoliberal. Sader (2013), por exemplo, afirma que os governos de Lula e Dilma quebraram o neoliberalismo dos governos de Fernando Collor de Mello, Itamar Franco e Fernando Henrique Cardoso. 
Contudo, para melhor compreender o assunto, faz-se necessário recordar como surgiu e vem se configurando o Partido que, desde a sua criação, na década de 1980, desfraldou a sua bandeira - o Partido dos Trabalhadores (PT).

Segundo Netto (2005), a edificação do PT

significou a construção de uma expressão política própria dos trabalhadores brasileiros, então em um período de fortalecimento social, e em um movimento em direção a sua independência política de classe (p. 82).

No entanto, é importante frisar que, nesse período, existia um suposto compromisso com uma futura transformação social no país, fato que deixou de acontecer com a ascensão do partido ao poder. Nessa ascensão, houve uma conversão, tanto política quanto ideológica, do então dito partido representante dos trabalhadores brasileiros. De acordo com Paula (2005), a vitória de Lula, em 2003, deveu-se ao insucesso das políticas neoliberais adotadas pelos governos Collor de Mello e Fernando Henrique Cardoso, que lhe antecederam. E a crença de que Lula/PT seria contrário a essas políticas, eram interpretados: "como instrumentos de mudança, como comprometidos com a distribuição de renda e da riqueza, como forças políticas contrárias ao neoliberalismo" (p. 32).

Na avaliação de Netto (2005), o PT começou a crescer desde a sua criação, quando nele havia setores relevantes da esquerda, pluralismo de ideias, democracia interna e vinculação com o socialismo, o que o tornava referência da esquerda no Brasil. Foi com esse perfil que Lula, como candidato da esquerda, alcançou muitos votos e chegou próximo a atingir a presidência em 1989, na disputa com o então candidato Collor. Mas, a partir de então, os ventos começaram a mudar de rumo; começou-se a fazer avaliações e inferências sobre o ocorrido e, aos poucos, outras estratégias para chegada de Lula ao poder foram ganhando corpo. Surgiram análises desse teor:

Lula como candidato de esquerda, sofreu forte rejeição por parte dos setores de grandes proprietários de terra, de empresários, e das classes médias mais abastadas. Tratava-se, naturalmente, de uma rejeição de classe. No entanto, o fato de o arco de apoios do segundo turno ter sido muito amplo (até o PSDB apoiou Lula) contribuiu para por num segundo plano o caráter de classe da polarização política básica e da rejeição da candidatura da esquerda. Assim, Lula e o círculo mais próximo a ele parecem ter concluído que a rejeição sofrida se devia basicamente a um suposto excesso de radicalismo, ou ainda a questão de natureza mais individual: a resistência da população a um "candidato sem diploma" (NETO, Id. p.83). 
Assim sendo, começou o fortalecimento da ideia de que o caminho para Lula e o PT seria o da ampliação de alianças e moderação do seu Programa de governo. Logo, a estratégia eleitoral tinha por detrás "o próprio desconhecimento dos antagonismos de classe inevitáveis na sociedade capitalista" (p. 83). Abandonou-se, aos poucos, a aposta no aumento da mobilização popular (isso foi evidente em 1994 e fortaleceu-se posteriormente). Lula e seu círculo mais próximo foram os que incitaram esse caminho; os que “mais impulsionaram no PT à 'moderação' e à diluição das referências socialistas, e que mais buscaram estabelecer vínculos cada vez mais fortes com os setores burgueses" (p.83/84).

A maneira como o conjunto do PT se desenvolveu internamente, foi desigual. Já nos anos de 1990, acrescenta Netto (idem), houve uma polarização entre direita e esquerda dentro do partido, em que pese essa divisão ter se tornado numericamente equilibrada, por volta da metade. Em 1993, o campo majoritário do PT- o setor liderado por Lula e Dirceu - dividiu-se e uma parte se juntou a outras correntes de esquerda. Isso fez com que, naquele momento, o campo majoritário no Partido, que era de esquerda, possibilitasse que a direita partidária se fizesse mais visível; e, com o tempo, esta fração foi modificando os vínculos sociais e referências políticas originais do Partido. Assim,

enquanto constituía laços crescentes com setores empresariais, distanciava-se das posições socialistas (...). De qualquer maneira, o fato é que a direção do campo majoritário do PT passou a identificar-se com as novas tendências da social-democracia internacional, integrando-se desde então, portanto, ao campo ideológico neoliberal (NETO, Id.p.84/85).

Entretanto, mesmo com o grupo majoritário, mais à direita, à frente, grande parte dos integrantes do PT, era contra o social-liberalismo então abraçado pela maioria do partido e tinha como direção o socialismo. Ressalte-se, ainda, que o PT durante o governo FHC era oposição, o que, no geral, fez com que fosse contrário ao neoliberalismo, oficialmente adotado por aquele governo. Netto assinala ainda que, não se pode subentender que a direção do PT ocultasse as suas convicções pela disputa política, pois havia hegemonia dessa corrente sobre a esquerda do PT; mas não havia homogeneidade, o que não lhe permitia tornar-se oficial dentro do partido. "Desta forma, embora a evolução do PT em direção a assimilação de ideias liberais tenha sido contínua, ela não foi sequer linear, nem coerente, nem isenta de contradições" (p. 86). Por isso, afirma Neto ( Idem): 
Não se trata de dizer que a direção do PT não dirigia o partido- ela dirigia, mas não podia fazê-lo inteiramente segundo sua própria linha política. Por outro lado, os setores de esquerda nunca puderam dirigir o PT, mas foram capazes de influenciar, até 2001, suas posições oficiais (p. 86).

Conforme relato deste autor, na Campanha Eleitoral de 2002, o Núcleo dirigente do Partido se sobressai. Lula determina a coligação com o Partido Liberal (PL) e recebe aprovação em reunião do Diretório Nacional, para ter como Vice na chapa, um grande empresário, com vistas a conquistar a confiança do grande capital. Dessa forma, "o projeto petista chamado democrático e popular, antes mesmo de o partido assumir a gerência do Estado, já havia sido superado nas contendas das lutas internas" (PINHEIRO, 2013, p.7).

Para Neto (2013), portanto, os governos do PT são evidentemente burgueses, pois sua ação segue a linha da "colaboração de classe" como se fosse possível o gerenciamento do Estado Burguês/capitalista brasileiro funcionar em benefício de todos. Daí as alianças do Partido inclusive com a extrema direita. Em vista disso, "a vitória eleitoral da candidatura de Lula em 2002 não significou uma vitória do desejo de mudanças da sociedade, embora tenha sido alimentada por esse sentimento, embora Lula se tenha declarado porta-voz dele, e embora o povo acreditasse nisso" (NETO, Idem, p.88).

Segundo Pomar (2014), o PT não possuía um projeto para a nação que visasse reformas estruturais e nem mesmo reformas que democratizassem o capitalismo brasileiro. Na sua Carta aos Brasileiros (ANEXO I), Lula manteve-se "centrado na implementação de programas mitigadores da pobreza e miséria” (p. 1). Para Sampaio Jr. (2014), a referida Carta, marca "o compromisso de subordinar a razão de Estado aos interesses estratégicos do grande capital" (p. 1), mostrando-se circunscrito aos limites e possibilidade dos governos do PT, com sua suposta proposta de Paz Social. Na verdade esses governos dispunham

de reduzidíssima margem de manobra para atender as demandas da população, pois dentro dos parâmetros da ordem global é impossível questionar a dupla articulação que garante a reprodução da situação de dependência e subdesenvolvimento (...). Nessas circunstâncias, a capacidade de legitimar o status quo e impedir a emergência do capitalismo social - condições indispensáveis para estabilidade do pacto do poder - depende particularmente do bom andamento dos negócios e da passividade das massas (p.1). 


\subsection{Mais utopia que realidade}

Assim sendo, em 2003, inicia-se no Brasil um governo de esquerda que busca governar com vistas a garantir a paz social, em uma conjuntura de crise estrutural do capital e de acirrada competitividade. E o (neo)desenvolvimentismo é eleito como o meio possibilitador dessa suposta façanha.

Façanha essa que não apresenta coerência com a realidade e nem exequibilidade. Trata-se de um falso intento desenvolvimentista de novo tipo com o objetivo de camuflar o continuísmo neoliberal em franco progresso. Este é que é o fato novo impeditivo de uma retomada brasileira do desenvolvimentismo vivenciado nos anos 1930. Nesses anos, afirma Sampaio Jr. (2009) a crise possibilitou a construção de uma economia nacional, com base num modelo desenvolvimentista via ISI (Industrialização por Substituição de Importação). Mas, agora não. Na realidade atual não há possibilidade de a crise ser uma "janela de oportunidades que permitiria um rearranjo da ordem internacional mais favorável às economias da região" (p. 128), visto que, agora o padrão de acumulação é pautado na mundialização do capital, na qual os países latino-americanos estão na periferia. Assim,

as frentes de valorização do capital dependem cada vez mais da integração da economia latino-americana na economia mundial e na abertura de novos negócios pela sistemática ampliação de formas predatórias e parasitárias de acumulação da riqueza. Na atualidade a preservação incólume dos mecanismos comerciais e financeiros que impulsionam a globalização dos negócios mantém a periferia atrelada ao centro cíclico. Ao comprometer os instrumentos de comando da política econômica, a ordem institucional liberal afasta a possibilidade de a crise internacional redundar em maior margem de manobra para as economias da região. (SAMPAIO Jr., 2009, p. 129)

Sampaio Jr. (Idem) ressalta ainda, que a burguesia nacional está compromissada com a ordem capitalista global, o que dificulta a edificação de respostas sólidas. Soma-se a esse quadro, segundo o autor, o fato de não se ter possibilidade real de sustentação de um desenvolvimento regional na atualidade, haja vista termos apenas "18 grupos empresariais entre os 100 maiores grupos dos países emergentes, sendo inferior a $2 \%$ o número de empresas de capital brasileiro e mexicano (...) entre as 2000 maiores corporações do mundo" (p. 131).

Voltando à nova CEPAL, uma das mentoras desse “(neo)desenvolvimentismo", no dizer de Carcanholo (2010), observa-se que, apesar dessa proposta tentar se colocar 
como intermediária, já começa a mostrar em que sentido caminha, pois, para o mesmo, não há como se colocar entre dois extremos: ela está claramente comprometida com reformas favoráveis ao mercado, que, como se sabe, ao mesmo tempo pioram os problemas das nações com economias dependentes. Ademais, segundo o autor, propagase uma visão muito rasteira ao se sustentar que Estado e mercado são opostos. Portanto, apesar de os defensores do neodesenvolvimentismo tentarem se diferenciar da ortodoxia neoliberal, não conseguem esse intento, pois, no fundo, legitimam uma neoliberalização em que o Estado está presente. Nas palavras do autor,

A agenda cepalina de "reforma das reformas" parece significar muito mais um gerenciamento das "imperfeições" das reformas neoliberais do que uma concepção significativamente distinta de desenvolvimento. No passado a Cepal caminhava em sentido contrário ao ideário liberalconservador-ortodoxo. Atualmente, acompanha o pensamento convencional, isso quando não vai a reboque do revisionismo, com seu modelo de "reforma das reformas" (CARCANHOLO, 2010, p. 138139)

Com efeito, de acordo com Castelo (2010), os novos desenvolvimentistas tem como base um mercado forte que depende de um Estado forte, que trabalhe com a regulação das atividades econômicas. Esse Estado, segundo o autor,

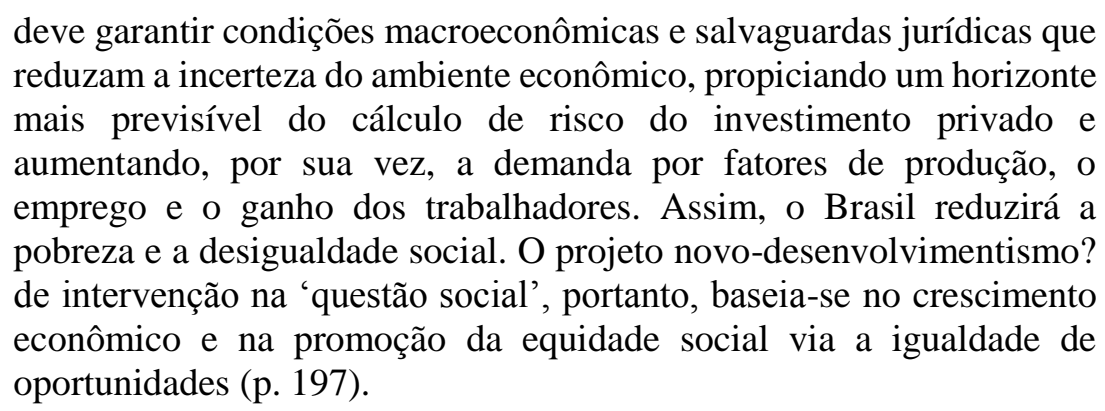

Para Castelo (Idem), a crítica aos neodesenvolvimentistas tem três aspectos de fundamental importância, a saber: "as funções históricas do Estado burguês, a dinâmica das lutas das frações de classe da burguesia e a integração dos aspectos sociais aos modelos heterodoxos de desenvolvimento" (p.198).

Em verdade, "retoma-se o antigo desenvolvimentismo com o prefixo 'novo' (neo) sem mediações históricas necessárias, a velha tragédia ganha, desta maneira, contornos de uma farsa contemporânea" (Idem, p. 622/623).

Disso decorre uma discrepância gigantesca entre o desenvolvimentismo e o (neo) desenvolvimentismo, assim exposto por Sampaio Jr. (2012): 
a perspectiva do velho desenvolvimentismo é um esforço de mostrar a necessidade inescapável de 'reformas estruturais' que desatem a dupla articulação responsável pelo caráter particularmente selvagem do capitalismo na periferia do sistema capitalista mundial. $\mathrm{O}$ neodesenvolvimetismo naturaliza a dupla articulação responsável pelo capitalismo dependente. Suas formulações ficam limitadas a elucubrações sobre a possibilidade de arquiteturas alternativas de políticas econômicas para administrar as estruturas. A perspectiva desenvolvimentista supõe a presença de sujeitos políticos dispostos a enfrentar o imperialismo e o latifúndio. Os novos desenvolvimentistas são entusiastas do capital internacional, do agronegócio e dos negócios extrativistas (...) na sua visão de mundo, desenvolvimento e fim da história caminham de mãos dadas (p. 685).

Veja-se, a seguir, quadro elaborado por Gonçalves (2011), que ilustra as discrepâncias entre o desenvolvimentismo brasileiro pioneiro eo neodesenvolvimentismo do governo Lula, supostamente baseado no primeiro.

\section{Quadro 1- Características do nacional desenvolvimentismo e do nacional desenvolvimentismo às avessas do governo Lula (neodesenvolvimentismo)}

\begin{tabular}{|c|c|}
\hline $\begin{array}{c}\text { Nacional } \\
\text { desenvolvimentismo }\end{array}$ & $\begin{array}{c}\text { Nacional } \\
\text { desenvolvimentismo às } \\
\text { avessas do governo Lula }\end{array}$ \\
\hline $\begin{array}{c}\text { Melhora do padrão de } \\
\text { comércio }\end{array}$ & $\begin{array}{c}\text { Reprimarização das } \\
\text { exportações }\end{array}$ \\
\hline $\begin{array}{c}\text { Avanço do sistema nacional } \\
\text { de inovações }\end{array}$ & $\begin{array}{l}\text { Maior dependência } \\
\text { tecnológica }\end{array}$ \\
\hline $\begin{array}{l}\text { Maior controle nacional do } \\
\text { aparelho produtivo }\end{array}$ & Desnacionalização \\
\hline $\begin{array}{l}\text { Ganhos de competitividade } \\
\text { internacional }\end{array}$ & $\begin{array}{c}\text { Perda de competitividade } \\
\text { internacional }\end{array}$ \\
\hline $\begin{array}{c}\text { Redução da vulnerabilidade } \\
\text { externa estrutural }\end{array}$ & $\begin{array}{c}\text { Crescente vulnerabilidade } \\
\text { externa estrutural }\end{array}$ \\
\hline Desconcentração de capital & $\begin{array}{c}\text { Maior concentração de } \\
\text { capital }\end{array}$ \\
\hline $\begin{array}{l}\text { Subordinação da política } \\
\text { monetária à política de } \\
\text { desenvolvimento }\end{array}$ & Dominação financeira \\
\hline Industrialização & Desindustrialização \\
\hline Substituição de importações & $\begin{array}{l}\text { Dessubstituição de } \\
\text { importações }\end{array}$ \\
\hline $\begin{array}{l}\text { Melhora do padrão de } \\
\text { comércio }\end{array}$ & $\begin{array}{l}\text { Reprimarização das } \\
\text { exportações }\end{array}$ \\
\hline
\end{tabular}

Segundo Almeida (2012), ao se comparar a literatura a respeito do governo Lula e Dilma (que sucedeu Lula, em 2010, e continua, num segundo mandato que termina em 2018), e dos governos neoliberais que os antecederam, verifica-se as seguintes posições: 1) a primeira é a de que existe sim, o (neo) desenvolvimentismo a partir do governo Lula, 
posição esta defendida pela Rede Desenvolvimentista; 2) a segunda, defende o desenvolvimento e, dessa forma, posiciona-se contrariamente à existência de um neodesenvolvimentismo, por este não ser condizente com o primeiro; 3) e a terceira que afirma ser, o (neo)desenvolvimentismo, uma nova versão/continuação do neoliberalismo.

Nesta dissertação, concorda-se com a terceira posição, por parecer a mais verdadeira. Mas, apesar de não se defender o desenvolvimentismo - segunda posição concorda-se com os seus adeptos quanto à falta de coerência entre o mesmo e o (neo)desenvolvimentismo, já apresentada anteriormente.

Dessa maneira, a autora desta dissertação coloca-se totalmente de acordo com a seguinte afirmação: "nenhum governo brasileiro pós-ditadura militar, e eleito diretamente pelo povo, rompeu com os mandamentos neoliberais, nem mesmo os que se identificavam com projetos de esquerda" (PEREIRA, 2012, p.740). Segundo Boito Jr. (2012), Lula e Dilma não romperam com o neoliberalismo, só “moderaram os [seus] efeitos negativos".

Como já salientado, em 2003, teve início o primeiro mandato do governo de Luiz Inácio Lula da Silva, que recebeu herança, às vezes considerada "maldita", dos seus antecessores. A transição do governo FHC foi, na realidade, uma opção pela continuidade do compromisso com o ideário neoliberal iniciado com o governo Colllor de Mello e consolidado com Fernando Henrique. Segundo Fonseca, Cunha e Bichara ${ }^{7}$ (2012), a própria escolha da equipe econômica do governo Lula evidenciam essa opção. No que concerne a economia,

o enfrentamento da credibilidade deu-se pelo aperto na política monetária e fiscal. Com seu conservadorismo inicial, o governo Lula logrou reverter as expectativas pessimistas, particularmente dos operadores dos mercados financeiros, com impactos positivos sobre a trajetória da inflação e o gerenciamento da divida pública (p.14).

Dessa forma, afirmam os autores, o Brasil ganhou destaque nas análises de órgãos multilaterais, analistas de mercado e acadêmicos; revelou-se uma força econômica frente aos impactos da crise e aos BRICs; e começou a se concretizar como nação, entendida então como potência econômica em ascensão. Seguindo sua política híbrida,

\footnotetext{
${ }^{7}$ Apesar de discordar das hipóteses defendidas pelos autores, faz-se, aqui, referências aos mesmos por trazerem dados e fatos relevantes para a análise do tema; não se tem a intenção de uma argumentação eclética, contudo deve-se lembrar que o que muda não é o dado em si, mas a forma de interpretá-lo e analisálo.
} 
deu, ao mesmo tempo, atenção a programas de assistência social e possibilitou o acréscimo da massa salarial e do consumo de bens-salário.

Ou seja, em tempo de crise a escolha da trilha do então presidente que representava a esperança das esquerdas, foi de manutenção/ aprofundamento do modelo neoliberal, de ajustamento da economia do país para tal fim e de conquista do apoio da burguesia. Consequentemente,

a rentabilidade dos bancos bateu recordes. O latifúndio expandiu até a Amazônia. Os mega-eventos turbinaram a especulação imobiliária enquanto investimentos faraônicos alimentavam a farra das empreiteiras. A privatização do petróleo descoberto na camada do présal gerou negócios bilionários. Os juros elevados continuaram sustentando o rentismo, enquanto as grandes operadoras ampliaram inescrupulosamente a exploração dos serviços públicos. O comércio internacional gerou lucros que lembravam a época da colônia. As multinacionais jamais venderam tantos automóveis e bugigangas. A especulação com "carry trade" transformou o Brasil num dos principais destinos do capital especulativo internacional (SAMPAIO JR. 2014, p.2)

Em busca da paz social, mesmo com essas saladas de coalizões e coligações (ANEXO II), esperava-se que o seu compromisso maior fosse com as classes populares. Afinal, Lula, na perspectiva de

honrar seus compromissos imediatos e históricos com a transformação social, só [poderia] contar com a força e combatividade, que vem das lutas sociais, dos movimentos e da ampla mobilização dos trabalhadores e demais setores populares" (PAULA, 2005, p.33).

Mas, isso não aconteceu. Os vínculos edificados com as classes populares iam, inclusive, no caminho contrário, de desmobilização, perda de autonomia e sufocamento. Para Oliveira (2010), Lula

havia sequestrado os movimentos sociais e a organização da sociedade civil. O velho argumento leninista-stalinista de que os sindicatos não teriam função num sistema controlado pela classe operária ressurgiu no Brasil de forma matizada" (p. 24).

E assim, como diz Neto, os vínculos "funcionam muito mais na direção oposta: para garantir a influência do governo sobre seus dirigentes e, a partir daí, para desmobilizar esses movimentos" (2005, p. 72).

O resultado foi que, "cooptou e corrompeu a maior parte de seus quadros, e não apenas suas direções”. (2013, p.5). Dessa maneira, e 
nos termos de Marx e Engels, da equação "força+consentimento" que forma a hegemonia desaparece o elemento "força". E o consentimento se transforma em avesso: não são mais os dominados que consentem sua própria exploração; são os dominantes- os capitalistas e o capital, explicite-se- que consentem em ser politicamente conduzidos pelos dominados, com a condição que a "direção moral" não questione a forma da exploração capitalista (OLIVEIRA, 2010, p.27).

Como explana Pereira (2012), o governo Lula optou por uma postura ambígua, tendo em vista que continuou com a herança recebida de FHC no mesmo passo que incorporou parte das reinvindicações das massas. Lula, além de continuar com a neoliberalização brasileira, ainda a intensificou. Consequentemente, essa intensificação recaiu negativamente sobre as políticas sociais e as condições de vida da classe trabalhadora. Sua atuação na área social mais considerável não chegou, de fato, a ser verdadeiramente significativa; mas, houve esforços destinados a combater a pobreza extrema, a princípio com o Programa Fome Zero e, depois, com o Programa Bolsa Família. Conseguiu também promover o crescimento econômico, mas não na dimensão da era desenvolvimentista. A ambiguidade de suas ações custou-lhe a perda de aliados de esquerda que o haviam apoiado nas suas candidaturas, ao mesmo tempo em que "ganhou um amplo leque de adesões à direita e à esquerda que lhe garantiu suporte político supra e policlassista" (Id., p. 745). Mas, vale ressaltar que "embora a base política que apoia o governo Lula seja muito heterogênea, o que é muito claro é que os setores mais à direita estão muito mais confortáveis nesse apoio do que os mais à esquerda" (NETO, 2005, p.73)

No seu segundo mandato o governo Lula expandiu a cobertura do PBF e diminuiu miséria no país, graças, segundo Pereira (Idem), a recuperação do crescimento econômico; o aumento real salário mínimo e do seu poder de compra; empenhou-se, igualmente, em atenuar a informalidade do trabalho, a incentivar o trabalho autônomo regulado e a expandir as micro/pequenas empresas, tendo como norte "a geração alternativa de trabalho e renda" (p. 745). Com esse desempenho, difundiu-se a ideia de que o país vivia uma era neodesenvolvimentista, o que não confere, na avaliação da autora; isso porque, há um paradoxo que deve ser levado em consideração: “esse governo melhorou, sim, as condições sociais de muitos brasileiros, mas, ao mesmo tempo, melhorou muito mais a remuneração do capital financeiro, industrial e do agronegócio que operam no país" (Idem, p.746). Dessa forma, 
se a pobreza absoluta ou extrema preocupou o governo, o combate à concentração de riqueza não foi alvo dessa preocupação. E o país continua injusto. Ademais, cabe registrar a adesão desse governo à ética capitalista neoliberal do workfare, que se expressa, seja na cobrança de contrapartidas dos beneficiários da assistência social pública, para livrá-los da dependência desta, seja na ativação imperiosa desses beneficiários para a sua inserção no mercado de trabalho com vista a sua autossustentação (Idem, p. 746/747).

O gráfico abaixo, mostra alguns dos resultados das escolhas preferenciais do governo Lula pelos banqueiros, um dos segmentos do capital mais beneficiado pelo projeto neodesenvolvimentista.

\section{GRÁFICO A - Lucro líquido dos onze maiores bancos}

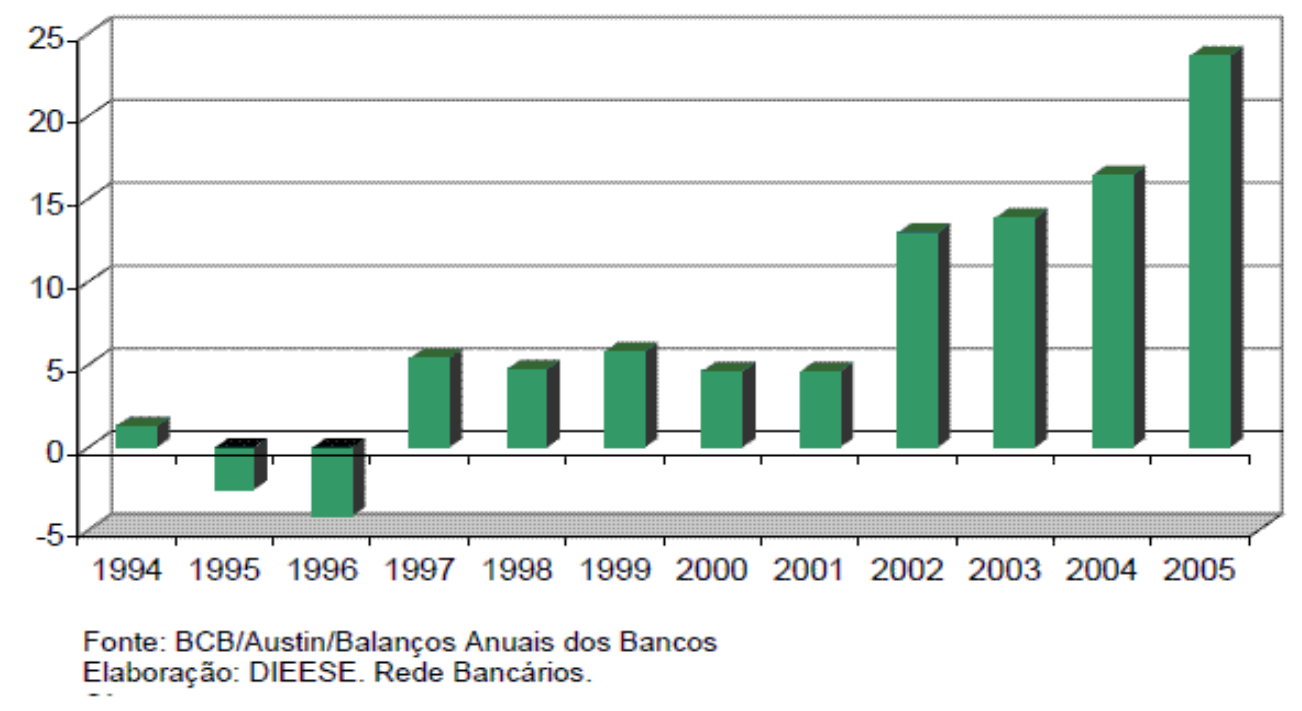

Todavia, o retorno do crescimento da economia, após anos de estagnação, deuse, conforme Sampaio Jr. (2014), graças ao aumento das exportações, da grande liquidez internacional e do endividamento familiar. As características desse retorno, segundo Boschetti (2013), "não são suficientes para assegurar um novo padrão de desenvolvimento econômico e social" (p. 7), pois, como afirma Neto (2013), ele é fraquíssimo se comparado à média histórica brasileira. Em outras palavras (POMAR, 2014, p.2), é insustentável, visto que "não houve adensamento das cadeias produtivas industriais" (p. 2). E, instável e decrescente ${ }^{8}$, segundo Boschetti (2013), como se pode verificar no quadro que se segue:

\footnotetext{
${ }^{8} \mathrm{O}$ que já pode ser visto no governo Dilma.
} 


\section{Quadro 2 - Crescimento do PIB e PIB per capita. Brasil, 2000-2012}

\begin{tabular}{|l|l|l|}
\hline Anos & PIB & $\begin{array}{l}\text { PIB } \\
\text { per } \\
\text { capita }\end{array}$ \\
\hline $\mathbf{2 0 0 0}$ & 4,3 & 2,8 \\
\hline $\mathbf{2 0 0 1}$ & 1,3 & $-0,2$ \\
\hline $\mathbf{2 0 0 2}$ & 2,7 & 1,2 \\
\hline $\mathbf{2 0 0 3}$ & 1,1 & $-0,2$ \\
\hline $\mathbf{2 0 0 4}$ & 5,7 & 4,3 \\
\hline $\mathbf{2 0 0 5}$ & 3,2 & 1,9 \\
\hline $\mathbf{2 0 0 6}$ & 4,0 & 2,7 \\
\hline $\mathbf{2 0 0 7}$ & 6,1 & 4,9 \\
\hline $\mathbf{2 0 0 8}$ & 5,1 & 4,0 \\
\hline $\mathbf{2 0 0 9}$ & $-0,3$ & $-1,3$ \\
\hline $\mathbf{2 0 1 0}$ & 7,5 & 6,5 \\
\hline $\mathbf{2 0 1 1}$ & 2,7 & 1,8 \\
\hline $\mathbf{2 0 1 2}$ & 0,9 & 0,1 \\
\hline \multicolumn{2}{|l}{} \\
\hline
\end{tabular}

Assim, da forma como foi processado, esse crescimento econômico não constituiu uma base sólida para construção de um novo padrão de desenvolvimento.

O mesmo pode ser dito a respeito da informação referente à redução da desigualdade social, também veiculada como fruto do neodesenvolvimentismo; redução essa baseada em números, contemplados no índice de Gini, publicado pelo IPEA, que revelam um decréscimo de 0,607, em 1990, para 0,527, 2011. No entanto, se se levar em consideração que diminuição da desigualdade é um processo que implica redistribuição de riqueza, e não apenas distribuição renda e, portanto, diminui a distância entre ricos e pobres, tal não aconteceu no Brasil - um país com uma das maiores concentração de riqueza do mundo.E mais, segundo Boschetti (2013), a redução da desigualdade, em 2011, de acordo com o índice de Gini está muito próxima do índice dos anos de 1960, que foi de 0,535 , e que foi, posteriormente confrontada com "uma forte agudização das desigualdades sociais nas décadas de 1970 e 1980" (p.8). Esta avaliação confirma o entendimento de Oliveira (2010) sobre o mesmo assunto, quando afirma não ser verdade essa redução, pois, com base nos estudos da FGV nos anos de 2003 a 2008, foram as classes $^{9}$ A e B que mais cresceram proporcionalmente, e isso segundo o autor, é sem levar em consideração "a valorização da propriedade, ações e investimentos financeiros" (p.

\footnotetext{
${ }^{9}$ Entendido aqui como grupos separados pelo poder de consumo e não classe social.
} 
374). Portanto, se esses fatos fossem levados em conta, a enorme discrepância entre ricos e pobres no país seria desnudada. Ou seja, o que aconteceu foi uma pequena redução da pobreza e o aumento do consumo dos mais pobres, mas daí dizer que o país é menos desigual, é mascarar a realidade, pois, a estrutura dessa desigualdade não foi alterada.

A sucessora de Lula na Presidência da República, foi Dilma Vana Rousseff; cabe ressaltar que, o seu segundo mandato ainda está em curso. Segundo Maciel (2012), já no processo eleitoral do ano de 2010 em que Dilma era candidata a eleição, o PT foi mais ainda para a direita, devido ao próprio perfil da disputa política que então se processara: Marina Silva, do Partido Socialista Brasileiro (PSB), apareceu como uma candidata que defendia um certo desenvolvimentismo econômico, aliado a uma preocupação com o meio ambiente e contra corrupção; mas, ela não questionava a base neoliberal de seus concorrentes, o que a induziu a ser uma candidata identificada com os setores mais conservadores. Serra vinculado ao Partido da Socialdemocracia Brasileira (PSDB) era o representante de um neoliberalismo mais intenso (mais radical), favorável à

\begin{abstract}
privatização do setor produtivo estatal, pela transferência para o mercado do controle e da regulação de setores econômicos essenciais, como no caso das agências reguladoras; pela desregulamentação dos direitos sociais e trabalhistas; por cortes significativos nos gastos sociais públicos e no serviço público (MACIEL, 2012, p. 2).
\end{abstract}

E a candidata vencedora, Dilma, que acenava com a proposta de um neoliberalismo mais moderado, continuação do governo Lula, o qual, de acordo com Maciel (2012), pode ser visto como algo que "[ampliaria] as políticas sociais compensatórias; [retomaria] a capacidade de financiamento do setor produtivo pelo Estado ou [chegaria] mesmo a ampliar os serviços sociais públicos e o próprio quadro de pessoal do serviço público" (p. 2). A disputa entre os candidatos não se definiu no primeiro turno, havendo necessidade de um segundo turno que se revelou acirrado e tenso entre Serra e Dilma, para a conquista do eleitorado de Marina, consideráveis 19,33\% dos votos no primeiro turno, com medo da ameaça de não chegar a esse eleitorado e consequentemente perder a eleição, Dilma adotou a pauta conservadora estabelecida. Acossada pelas forças conservadoras e de parcelas significativas das classes sociais abastadas que mais se beneficiaram com o projeto neodesenvolvimentista de Lula, Dilma, uma vez eleita deu uma forte guinada para a direita na tentativa de garantir a governabilidade de seu mandato. E foi ai que o projeto neodesenvolvimentista perdeu qualquer aparência de realidade. Quanto à esquerda socialista, esta não conseguiu se mobilizar em torno de um projeto comum, não alcançando, no processo eleitoral, nem $1 \%$ 
dos votos no somatório de todos os seus candidatos. Assim, o conjunto da esquerda brasileira ficou em situação difícil e acabou se vendo na situação, segundo o autor, do “ruim com Dilma, pior com Serra".

A sua entrada no governo em 2011, calhou com um momento em que a paz social como estratégia de governo do PT estava começando a desmoronar. “A exaustão do ciclo de crescimento e a retomada das mobilizações sociais deram início a uma conjuntura de progressiva instabilidade econômica e crescente conflito social” (SAMPAIO JR., 2014, p. 2)

O cenário mundial estava bem distinto do quadro anterior, quando Lula era presidente. Segundo Pomar (2014), a crise do capitalismo estadunidense havia chegado a Europa. "E suas marolas bateram pesado nas praias do nosso crescimento baseado no consumo e nas exportações de commodities" (p.2). De acordo com Sampaio Jr. (2014), houve uma reversão do crescimento brasileiro; nas considerações do autor

\begin{abstract}
os antagonismos provocados pelo aprofundamento do subdesenvolvimento e da dependência começam a emergir. $\mathrm{O}$ aumento do emprego veio acompanhado de crescente precarização do trabalho. A especulação imobiliária provocada pelos mega-eventos agravou o problema da falta de moradia. O boom de venda de automóveis agudizou os problemas de mobilidade urbana. O descaso com as condições de vida da população levou a crise urbana ao ponto de ebulição. A escalada no consumo de bens supérfluos veio acompanhado de crescente deterioração da oferta de bens e serviços essenciais: educação, saúde, habitação, transporte público, segurança, cultura e lazer. O desperdício de recursos em investimentos despropositados tinha como efeito obrigatório a penúria de recursos para políticas públicas (p. 2-3)
\end{abstract}

E assim, segundo Maciel (2012), as medidas escolhidas para serem adotadas pela presidência, não foram, de forma alguma, na linha de um real (neo) desenvolvimentismo. Pelo contrário, foram medidas de caráter neoliberal intenso: "o governo reagiu cortando gastos, subindo juros, privatizando e aprofundando a simbiose entre acumulação privada e recursos públicos" (p.4). Isso demonstra a quem beneficiou de fato o projeto políticoeconômico brasileiro chamado de neo desenvolvimentista.

Seu compromisso orgânico com os interesses do grande capital, particularmente do financeiro, em detrimento das classes trabalhadoras, pois o corte com despesas, a maioria delas de caráter social, foi devidamente contra arrestado pelo aumento automático na dívida pública motivado pela alta dos juros (MACIEL, 2012, p. 5). 
Faz-se possível verificar, ao modo de Pereira (2012), ao se referir ao Plano Brasil sem Miséria, que o primeiro governo Dilma apresentou as seguintes tendências: "ultrafocalização ou o princípio de minimalíssima elegibilidade, associadas à prevalência do workfare (bem-estar em troca de [qualquer] trabalho) sobre o welfare" (bem-estar como direito) (Id., p.747).

Para complementar o entendimento da dinâmica do financiamento da política "neodesenvolvimentista" brasileira, vale refletir sobre os seguintes dados:

Orçamento de 2011: 45\% para os juros da divida; 4,07 para a Saúde, 2,99\% para educação; $2,85 \%$ para a assistência social (onde está o PBF)[...];0,12\% para reforma agrária e $0,41 \%$ para a segurança pública. Sobre a Desvinculação das Receitas da União (DRU), entre 2005 e 2010 foram 'expropriados' do OSS: R\$228.743 bilhões (aproximadamente U\$170,3 bilhões em março de 2012), o que equivale a quatro vezes os gastos com saúde em 2010 e seis vezes o orçamento da assistência social nesse mesmo ano (BEHRING, p. 9/10).

Perante o exposto, Behring afirma que: "produzimos mudanças. Mas estas não permitem deduzir que adentramos no pós-neoliberalismo e num ambiente reformista" (Id., p.2). Para a autora, continua-se com os elementos centrais da agenda neoliberal, tanto na economia, quanto na política social. Dessa forma, na dinâmica brasileira contemporânea, as consequências da hegemonia neoliberal se tornam "avassaladoras" (Id., p. 11). Assim, o neoliberalismo que se vive hoje é menos extremado, segundo Neto (2013), “ isto não tem nada a ver com os governos do PT (que, pelo contrário, reforçaram, de conjunto, o neoliberalismo, ainda que tenha introduzido pequenas modificações em seu curso), e sim com a crise internacional" (p. 5). Dessa forma, o Partido dos Trabalhadores, "é um excelente exemplo do movimento de constituição de uma classe contra a ordem do capital que acaba por amoldar-se aos limites da ordem que queria superar" (IASI, 2012 apud SOLER, 2015, p. 6).

No seu segundo mandato, o governo Dilma sacramentou a sua tendência à acomodação. Sua estratégia de compor com os neoliberais e conservadores tem-lhe cobrado um preço alto. Os ajustes fiscais que implementou logo no início de seu segundo governo têm-se mostrado equivocados. Penalizam ainda mais a classe trabalhadora e não garantiram adesão de seus contendores. A montagem de quadros no seu segundo governo dá mostras suficientes de sua opção pelo conservadorismo. Vide quadro que se segue: 
Quadro 3- Composição do governo Dilma no segundo mandato

\begin{tabular}{|c|c|c|}
\hline \multicolumn{3}{|c|}{ Governo Dilma 2o Mandato } \\
\hline Pasta & Ministro & Partido \\
\hline Agricultura & Kátia Abreu & PMDB \\
\hline Assuntos Estratégicos do Brasil & $\begin{array}{l}\text { Roberto Mangabeira } \\
\text { Unger }\end{array}$ & s/ partido \\
\hline Casa Civil & Aloísio Mercadante & PT \\
\hline Ciência e Tecnologia & Aldo Rebelo & PC do B \\
\hline Comunicação Social & Edinho Silva & PT \\
\hline Comunicações & Ricardo Berzoini & PT \\
\hline Cultura & Juca Ferreira & PT \\
\hline Defesa & Jacques Wagner & PT \\
\hline Desenvolvimento Industria e Comércio Exterior & Armando Monteiro & PTB \\
\hline Desenvolvimento Agrário & Patrus Ananias & PT \\
\hline Educação & Renato Janine Ribeiro & s/ partido \\
\hline Esporte & George Hilton & PRB \\
\hline Fazenda & Joaquim Levy & s/ partido \\
\hline Integração Nacional & Gilberto Occhi & $\mathrm{PP}$ \\
\hline Justiça & José Eduardo Cardozo & PT \\
\hline Meio Ambiente & Izabella Teixeira & s/ partido \\
\hline Minas e Energia & Eduardo Braga & PMDB \\
\hline Cidades & Gilberto Kassab & PSD \\
\hline Pesca e Aquicultura & Helder Barbalho & PMDB \\
\hline Planejamento Orçamento e Gestão & Nelson Barbosa & s/ partido \\
\hline Previdência & Carlos Eduardo Gabas & PT \\
\hline Saúde & Arthur Chioro & PT \\
\hline Desenvolvimento Social e Combate a Fome & Tereza Campello & PT \\
\hline Relações Exteriores & Mauro Vieira & s/ partido \\
\hline Trabalho e Emprego & Manoel Dias & PDT \\
\hline Transportes & Antonio Carlos Rodrgues & PDT \\
\hline Turismo & Henrique Eduardo Alves & PMDB \\
\hline Secretaria de Aviação Civil & Eliseu Padilha & PMDB \\
\hline Secretaria de Micro e Pequena Empresa & Guilherme Afif Domingos & PSD \\
\hline $\begin{array}{l}\text { Secretaria de Políticas de Promoção da Igualdade } \\
\text { Racial }\end{array}$ & Nilma Lino Gomes & s/ partido \\
\hline Secretaria Especial de Políticas para as Mulheres & Eleonora Menicucci & PT \\
\hline Secretaria de Estado dos Direitos Humanos & Pepe Vargas & PT \\
\hline Secretaria de Portos & Edson Coelho Araújo & PMDB \\
\hline Secretaria-Geral da Presidência & Miguel Rossetto & PT \\
\hline Controladoria-Geral da União & Valdir Moysés Simão & s/ partido \\
\hline Advocacia Geral da União & Luís Inácio Adams & s/ partido \\
\hline
\end{tabular}




\begin{tabular}{|l|l|l|}
\hline Gabinete de Segurança Institucional & $\begin{array}{l}\text { José Elito Carvalho } \\
\text { Siqueira }\end{array}$ & s/ partido \\
\hline Banco Central & Alexandre Tombini & s/ partido \\
\hline
\end{tabular}

Quadro: Elaboração própria

E isso tudo em um momento cuja conjuntura internacional continua sendo de crise, segundo Grabois (2014), na qual a economia do Brasil está patinando, no mesmo passo em que há diminuição no ritmo chinês; a União Europeia está estagnada; os Estados Unidos estão ora em recessão, ora em recuperação. 


\section{CAPÍTULO 3}

\section{A POLITICA SOCIOASSISTENCIAL NO CONTEXTO DO "NEODESENVOLVIMENTISMO"}

\subsection{Ressignificação da assistência social nos marcos da Constituição Federal de 1988.}

A assistência social brasileira é antiga remetendo-se à época em que o Brasil ainda era colônia lusitana. Sua atuação era pautada pelo signo do não direito, característica esta que, guardadas as variações históricas de sua prática, prevaleceu até os anos 1980, quando ocorreu a última redemocratização do país, após vinte e um anos de ditadura civil-militar. Nesse longo período, sua trajetória foi assistencialista, isto é, emergencial, paliativa; ou, como denomina Pereira (2007), de desassistência dos legítimos reclamos sociais da sociedade, visto que o atendimento efetivo das necessidades básicas contidas nesses reclamos não era o objetivo a ser alcançado. Essa assistência era exercida, segundo Couto (2010), com recursos parcos, no âmbito das relações pessoais e, predominantemente, como iniciativa privada.

Contudo, com a promulgação da Constituição Federal, em 1988, a assistência social, no Brasil, mudou de status. Passou a compor o sistema de Seguridade Social, então recém-inaugurado no país, ao lado da Saúde e da Previdência - duas políticas consideradas básicas pela opinião pública nacional - e a ser vista como direito do cidadão e dever do Estado. Sua regulamentação ocorreu, não sem pressão de parcelas organizadas da sociedade e resistências institucionais e políticas, em 7 de dezembro de 1993, pela Lei Orgânica de Assistência Social (Lei n 8.742). E nessa condição, ela deixou de ser uma ação casual e espontânea, tornando-se uma política pública.

É importante ressaltar que esse processo contou, segundo Couto (2010), com a propagação das ideias, tanto em âmbito nacional quanto internacional, relacionadas aos direitos humanos e ao atendimento das necessidades dos trabalhadores para além das insuficientes legislações do trabalho; assim como com o adensamento de pessoas que anteriormente não eram consideradas público alvo da assistência social e que, naquele momento, não eram mais atendidas pelas políticas voltadas ao trabalho, entrando assim em cena, muitas se reconhecendo como sujeito de direitos.

Dessa forma, a Constituição vigente significou uma importante reforma democrática, posto que constituiu um marco da recente redemocratização do país e, como 
tal, passou, "ainda que tardiamente, a requerer a institucionalização e a regulação da assistência social, retirando-a da posição residual e incerta a que sempre esteve confinada" (PEREIRA, 1996, p. 92).

Mas, toda essa ressignificação se deu no plano formal. Na vida real, a Carta Magna brasileira remava contra a corrente da onda neoliberal que inundava o mundo e penetrava no Brasil de forma crescente, com o aval dos governos eleitos pelo voto popular. Consequentemente, a assistência social que mal havia sido legalmente reconhecida como direito social, teve que enfrentar um cenário de desmonte desses mesmos direitos por se incompatibilizarem com os valores individualistas e mercadológicos do neoliberalismo dominante.

Mesmo assim, desde a sua regulamentação, a política pública de assistência social conseguiu contar com os seguintes marcos legais: Lei Orgânica da Assistência Social (LOAS) - Lei 8.742/ 1993, já mencionada; Política Nacional de Assistência Social - 2004; Norma Operacional (NOB)- 2004; Sistema Único de Assistência Social (SUAS) - 2005; Tipificação Nacional dos Serviços Socioassistenciais- 2009; Lei 12.435/ 2011 que altera a LOAS, sendo que, das políticas da Seguridade Social foi a última a ser regulada, pois a saúde obteve regulamentação em 1990, e seu Sistema Único em 1991, e a previdência social também em 1991. Assim, afora a LOAS-93, todos os demais marcos legais foram instituídos nos governos de Lula e Dilma. E é sobre os rumos que a assistência social tem tomado sob a governança petista, denominada "neodesenvolvimentista" que incide a análise que se segue.

Primeiramente, expõem-se os avanços no campo assistencial propagados no período compreendido entre 2003-2014, para, em seguida, fazer-se análise crítica dos mesmos. O ponto culminante desse avanço, em torno do qual se centram atenções variadas - condenatórias ou defensoras -, inclusive nesta dissertação, diz respeito ao orçamento no qual o gasto com assistência social pela primeira vez apresentou aumentos significativos comparados com o eterno subfinanciamento desta política, através dos tempos.

Efetivamente, do ponto de vista da alocação de ativos monetários, o Estado brasileiro está destinando mais recursos aos gastos sociais e, nestes, aos programas ditos assistenciais. Percebe-se, quanto a essa tendência, uma trajetória crescente, especialmente a partir de 2003, quando se inicia o governo Lula. Esse aumento pode ser visualizado, até 2010, no gráfico B, abaixo: 


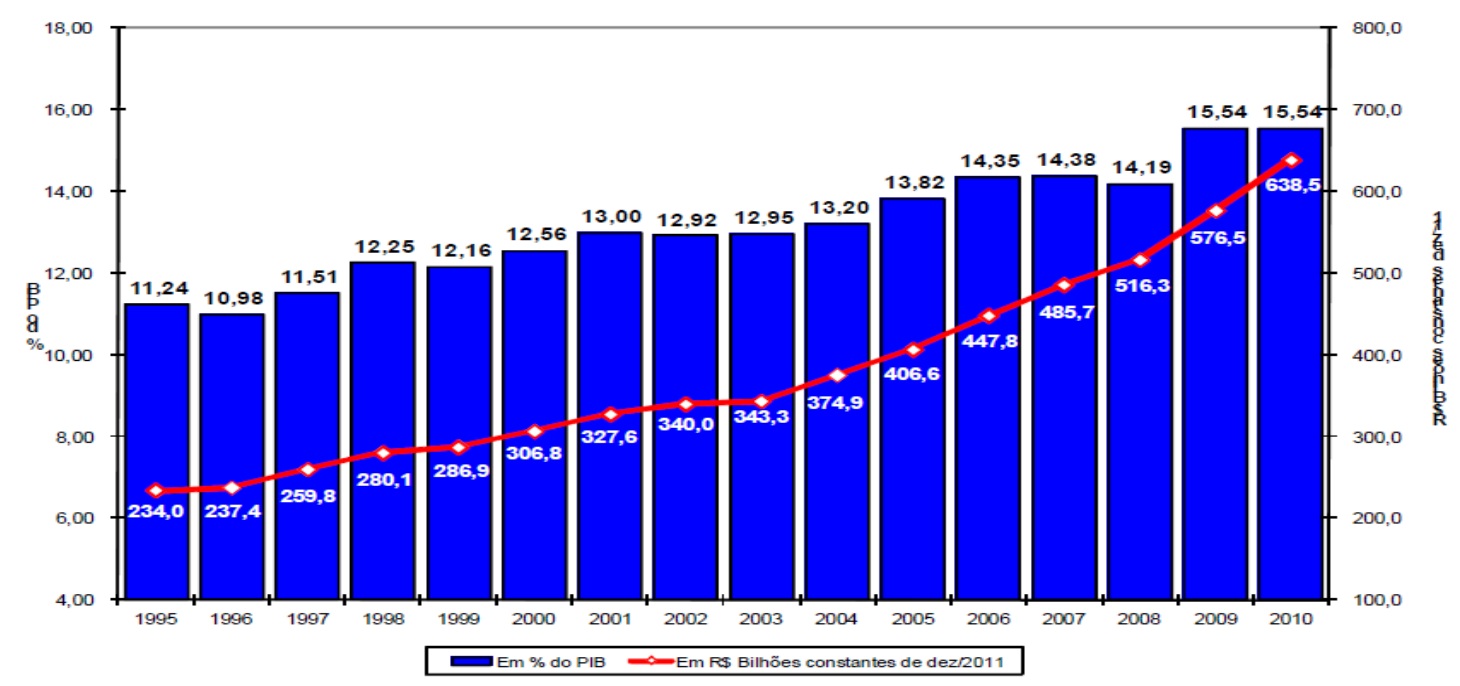

Fonte: Castro (2012). Nota técnica - Gasto Social Federal: prioridade macroeconômica no período 1995-2010. IPEA Set. 2012.

Quanto ao orçamento específico da Seguridade Social, este se elevou, aproximadamente, de 169 bilhões de reais ${ }^{10}$ no início do governo Lula, em 2003, para quase 640 bilhões de reais até final do primeiro mandato do governo Dilma, em 2014. É o que revela o gráfico $\mathbf{C}$ apresentado a seguir, no qual se observa a trajetória ascendente de destinação dos recursos monetários de cada política que compõe a Seguridade.

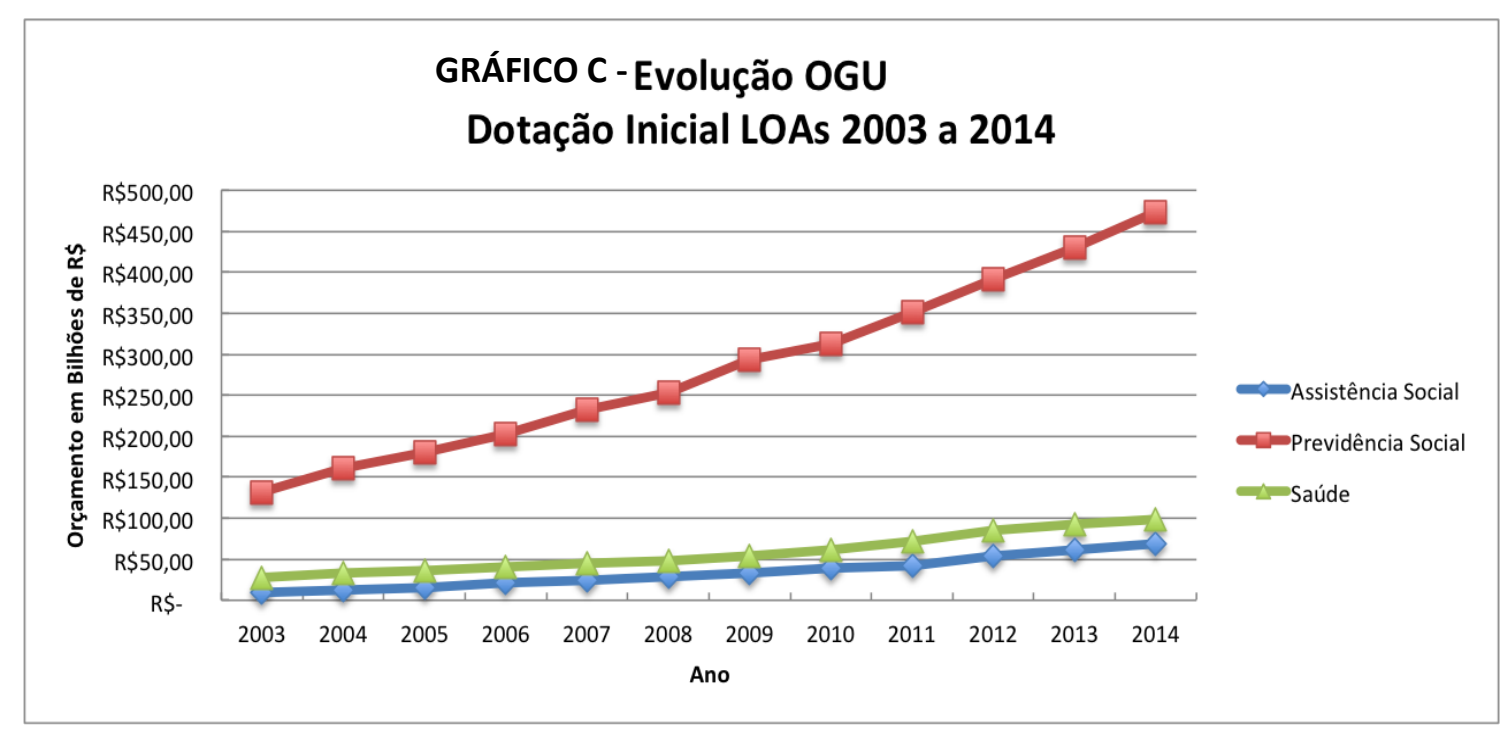

Elaboração própria. Fonte: dados Siga Brasil (2015)

Neste gráfico, constata-se que houve um aumento pouco usual de recursos destinados à assistência social, a ponto de, pela primeira vez na história da proteção social

\footnotetext{
${ }^{10}$ Valores passados a seguridade social, assim como os valores passados a cada política que a compõe no primeiro e segundo mandato governo Lula e no primeiro mandato governo Dilma, ano por ano estão descriminados no anexo III.
} 
brasileira, esta política aproximar-se da saúde em matéria de financiamento público; e isso gerou convergências críticas entre direita e esquerda do espectro político nacional, sobre uma possível retomada do paternalismo pelo governo. Ou seja, para essa crítica, a assistência social continuava identificada com o seu passado assistencialista e não com o novo status que lhe foi conferido pela Constituição de 1988.

Contudo, como também pode ser visualizado nos gráficos $\mathbf{D}$ e $\mathbf{E}$ abaixo, o montante de recursos destinado à assistência não ultrapassou o da saúde e muito menos o da previdência social, mesmo havendo um salto no financiamento de menos de $5 \%$, em 2003, para 10\% em 2013 no campo assistencial. No ano de 2014 essa destinação já alcançava $11 \%$ do orçamento da Seguridade Social, ou seja, mais que o dobro durante esse período.

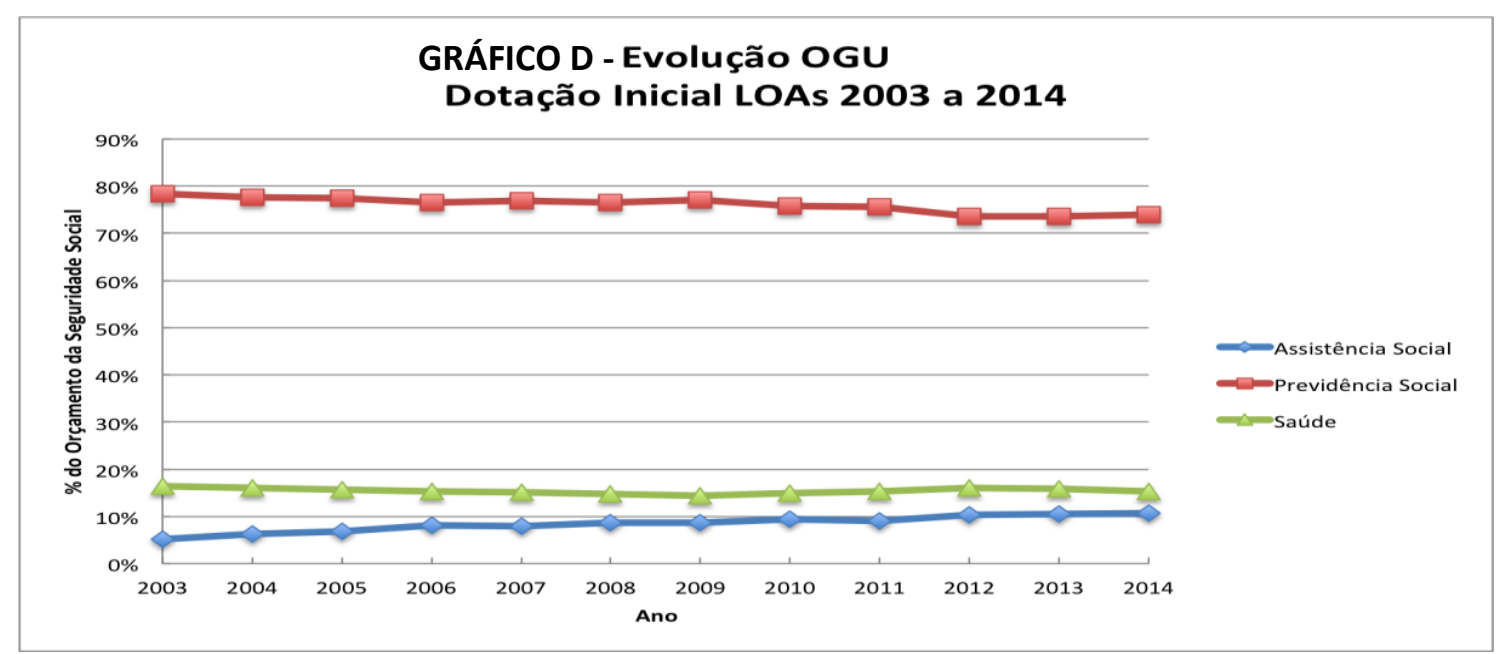

Elaboração própria

Fonte dados: SIGA Brasil (2015)

\section{GRÁFICO E - Seguridade Social Dotação Inicial LOA 2014}

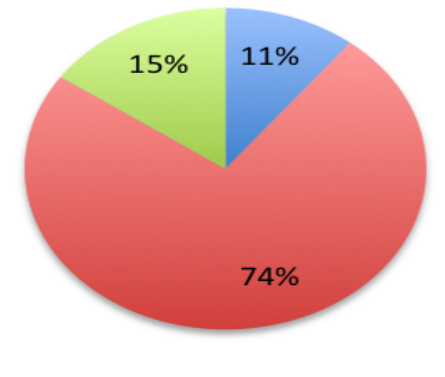

- Assistência Social

- Previdência Social

- Saúde

Elaboração própria. Fonte dados: SIGA Brasil (2015) 
Todavia, no âmbito da assistência social, a distribuição do montante de recursos que lhe foi destinado apresenta, um desequilíbrio de prioridades entre transferência de benefícios monetários e oferta de serviços assistenciais. E ai reside uma tendência passível de crítica consistente relacionada não ao paternalismo, mas sim à monetarização da proteção assistencial; monetarização esta que é compatível com a propensão neodenvolvimentista de medir o bem-estar da população pela sua possibilidade de consumo de produtos oferecidos pelo mercado. Assim, em 2014, dos recursos destinados à assistência, $87 \%$ foram alocados nos Programa de Transferência de Renda: Benefício de Prestação Continuada (BPC), previsto na Constituição Federal, e o Programa Bolsa Família (PBF), destinado a famílias pobres e extremamente pobres. Vide gráfico $\mathbf{F}$ referente a esse último ano do primeiro mandato de Dilma Rousseff.

\section{GRÁFICO F - Assistência Social Dotação Inicial LOA 2014}

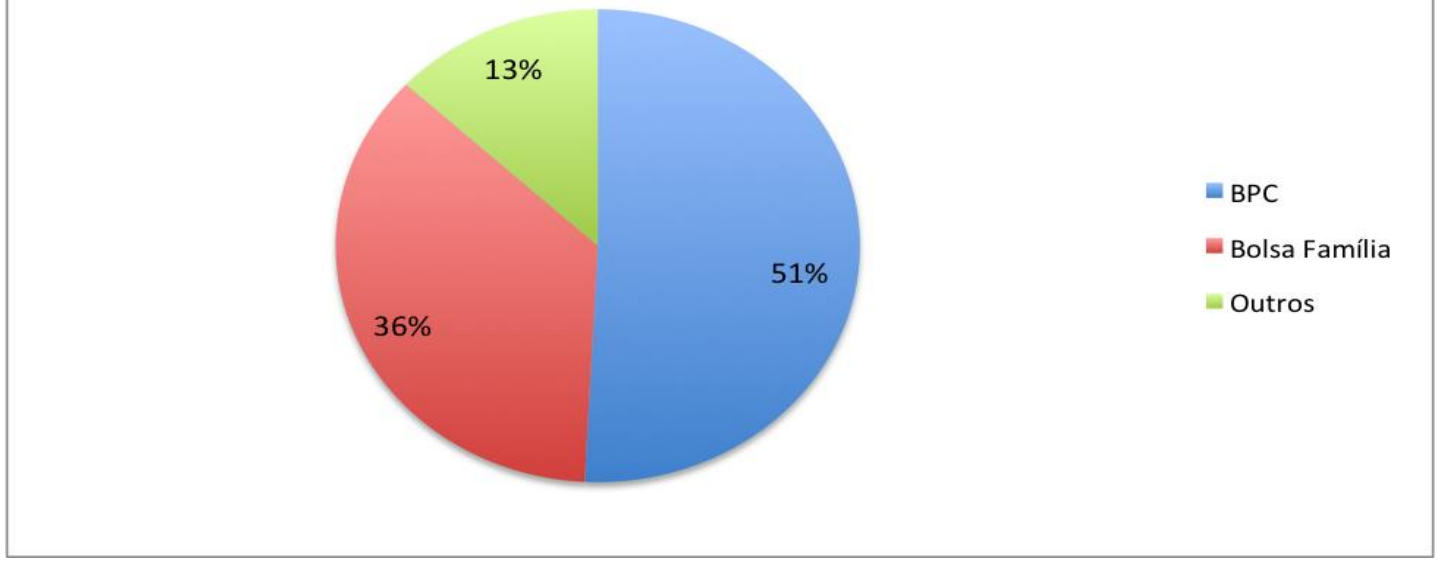

Elaboração própria

Fonte dados: SIGA Brasil (2015)

É voz corrente que, sob o domínio dos governos Lula e Dilma a nação se tornou menos desigual. De fato, como se pode verificar por meio do índice de Gini, no gráfico que se segue, houve uma redução nesse quesito em comparação com os governos anteriores. Segundo IPEA (2012), um dos fatores responsáveis por essa redução foi o PBF. Para esse Instituto de Pesquisa, o referido Programa faz parte de um novo conjunto de fontes de ativos da população de baixa renda que possibilitaram a esta aumentar suas possibilidades de consumo; e nesse conjunto a sua participação foi de $13 \%$. 
GRÁFICO G: Índice de Gini

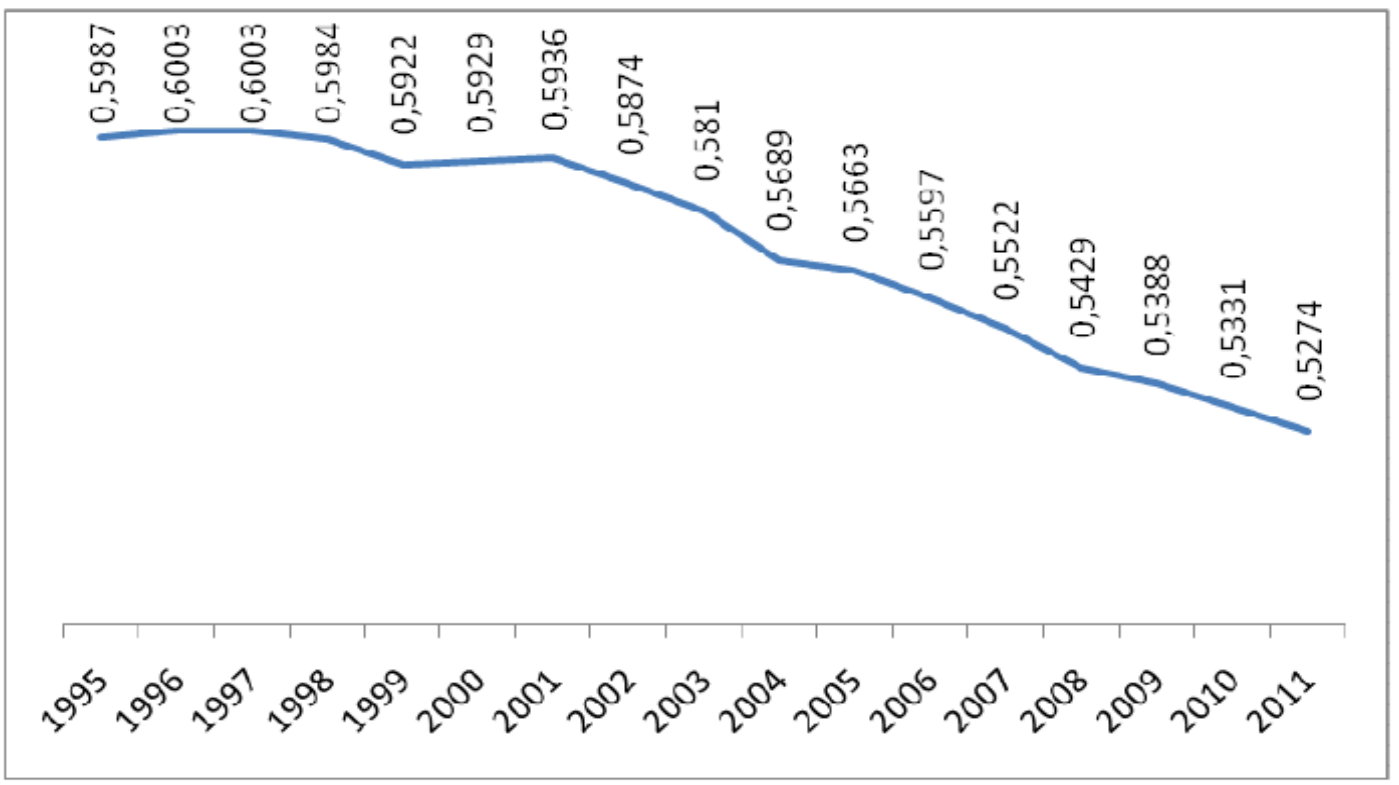

Fonte: IPEA (2012).

Dados: Microdados Pnads de 1995-2011

Tal diagnóstico assenta-se na constatação de que, entre 2003 e 2014, ocorreu uma redução contínua e considerável, para os padrões históricos, da pobreza (e não propriamente da desigualdade) na nação brasileira. Chegou-se a atingir, num prazo de seis anos, as Metas do Milênio, previstas pela ONU, para serem alcançadas em 25 anos. O país saiu do Mapa da Pobreza, constata o IPEA (2013), pois mais de 12 milhões de pessoas saíram da pobreza extrema, enquanto 28 milhões deixaram de ser pobres. Para muitos, esses 28 milhões de pessoas ascenderam à classe média, o que tem gerado discussões que não são aqui tratadas por fugirem do interesse central deste estudo. Vide gráfico abaixo, sobre essa evolução:

GRÁFICO H: Evolução da pobreza segundo o número de pobres.

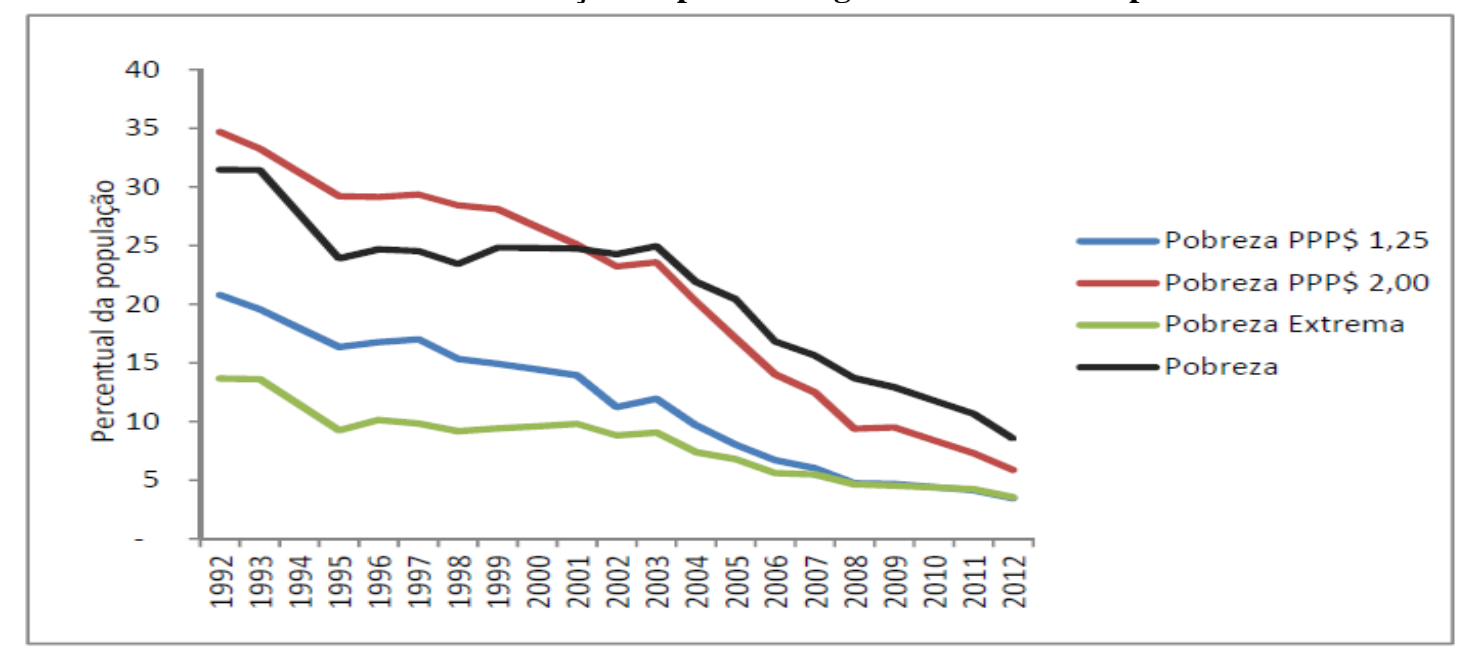

Fonte: IPEA (2013).

Dados: Microdados das Pnads 1992-2012 
O PBF entrou nessa conjuntura em 2003, quando foi criado no governo Lula pela Medida Provisória n $^{\circ} 132$ e instituído, posteriormente, pela Lei 10.836/04. Ele foi fruto da junção de programas isolados, preexistentes, de transferência de renda, nos diferentes níveis da federação, a saber: Bolsa alimentação; Bolsa escola; Auxílio Gás; Cartão alimentação. Volta-se para famílias pobres e extremamente pobres, tendo como critério de elegibilidade a renda per capita de até $\mathrm{R} \$ 154,00$, sendo extremamente pobres os que possuem menos de $\mathrm{R} \$ 77,00$ per capita. As famílias pobres só podem requerer o seu ingresso se tiverem em sua composição familiar crianças, adolescentes de até 17 anos de idade, gestantes e mãe que ainda amamenta. Compondo o PBF, existem quatro tipos de benefício: básico, superação da pobreza extrema, variável e variável vinculado ao jovem. Os valores a serem repassados é baseado no perfil registrado no Cadastro Único ${ }^{11}$. As famílias que recebem o benefício básico são as extremamente pobres; as que recebem o de superação da pobreza extrema são aquelas que mesmo acessando outros benefícios do PBF não conseguem sair da pobreza extrema. Vide quadro abaixo com os respectivos valores:

Quadro 4- Valores dos benefícios em R\$ de acordo com a composição familiar

Famílias com renda per capita familiar mensal de até $\mathbf{R} \$ 77$

\begin{tabular}{|c|c|c|c|c|c|c|c|}
\hline \multicolumn{4}{|c|}{ ate $\mathrm{Rs} / /$} & \multicolumn{4}{|c|}{ К\$ // a K\$ 154} \\
\hline $\begin{array}{l}\text { Número } \\
\text { de } \\
\text { gestantes, } \\
\text { nutrizes, } \\
\text { crianças e } \\
\text { adolescen } \\
\text { tes de até } \\
15 \text { anos }\end{array}$ & $\begin{array}{l}\text { Núme } \\
\text { ro de } \\
\text { jovens } \\
\text { de } 16 \\
\text { e } 17 \\
\text { anos }\end{array}$ & Tipo de benefício & $\begin{array}{l}\text { Valor do } \\
\text { Benefício }\end{array}$ & $\begin{array}{l}\text { Número } \\
\text { de } \\
\text { gestantes, } \\
\text { nutrizes, } \\
\text { crianças e } \\
\text { adolescent } \\
\text { es de até } \\
15 \text { anos }\end{array}$ & $\begin{array}{l}\text { Núme } \\
\text { ro de } \\
\text { jovens } \\
\text { de } 16 \\
\text { e } 17 \\
\text { anos }\end{array}$ & Tipo de benefício & $\begin{array}{l}\text { Valor do } \\
\text { Benefício }\end{array}$ \\
\hline $\mathbf{R} \$ 35,00$ & $\begin{array}{c}\mathrm{R} \$ \\
42,00\end{array}$ & & & $\mathrm{R} \$ 35,00$ & $\begin{array}{c}\mathrm{R} \$ \\
42,00\end{array}$ & & \\
\hline $\mathbf{0}$ & 0 & Básico & $\mathrm{R} \$ 77,00$ & 0 & 0 & Básico & $\mathrm{R} \$ 0,00$ \\
\hline $\mathbf{1}$ & 0 & Básico+1variável & $\begin{array}{r}\mathrm{R} \$ \\
112,00\end{array}$ & 1 & 0 & Básico+1variável & $\mathrm{R} \$ 35,00$ \\
\hline 2 & 0 & Básico+2variáveis & $\begin{array}{r}\mathrm{R} \$ \\
147,00\end{array}$ & 2 & 0 & $\begin{array}{l}\text { Básico+2variávei } \\
\text { s }\end{array}$ & $\mathrm{R} \$ 70,00$ \\
\hline 3 & 0 & Básico+3variáveis & $\begin{array}{r}\mathrm{R} \$ \\
182,00\end{array}$ & 3 & 0 & $\begin{array}{l}\text { Básico+3variávei } \\
\text { s }\end{array}$ & $\mathrm{R} \$ 105,00$ \\
\hline 4 & 0 & Básico+4variáveis & $\begin{array}{r}\mathrm{R} \$ \\
217,00\end{array}$ & 4 & 0 & $\begin{array}{l}\text { Básico+4variávei } \\
\text { s }\end{array}$ & $\mathrm{R} \$ 140,00$ \\
\hline 5 & 0 & Básico+5variáveis & $\begin{array}{r}\mathrm{R} \$ \\
252,00\end{array}$ & 5 & 0 & $\begin{array}{l}\text { Básico+5variávei } \\
\mathrm{s}\end{array}$ & $\mathrm{R} \$ 175,00$ \\
\hline $\mathbf{0}$ & 1 & Básico + 1 BJV & $\begin{array}{r}\mathrm{R} \$ \\
119,00\end{array}$ & 0 & 1 & Básico + 1 BJV & $\mathrm{R} \$ 42,00$ \\
\hline 1 & 1 & $\begin{array}{l}\text { Básico } \\
+1 \text { variável+1 BVJ }\end{array}$ & $\begin{array}{r}\mathrm{R} \$ \\
154,00\end{array}$ & 1 & 1 & $\begin{array}{l}\text { Básico } \\
+1 \text { variável+1 } \\
\text { BVJ }\end{array}$ & $\mathrm{R} \$ 77,00$ \\
\hline 2 & 1 & $\begin{array}{l}\text { Básico } \\
+2 \text { variáveis+1 } \\
\text { BVJ }\end{array}$ & $\begin{array}{r}\mathrm{R} \$ \\
189,00\end{array}$ & 2 & 1 & $\begin{array}{l}\text { Básico } \\
+2 \text { variáveis+1 } \\
\text { BVJ }\end{array}$ & $\mathrm{R} \$ 112,00$ \\
\hline
\end{tabular}

${ }^{11}$ Para participar do PBF é preciso se inscrever no referido cadastro e manter os dados atualizados. Têm prioridade as famílias com menor renda. O Cadastro Único é um cadastro para os programas sociais em nível federal; registra informações sobre famílias de baixa renda - renda de até 1/2 salário mínimo per capita ou 3 salários por família. O governo se utiliza do mesmo para, além de conhecer as famílias, organizar a oferta dos serviços públicos para população. 


\begin{tabular}{|c|c|c|c|c|c|c|c|}
\hline 3 & 1 & $\begin{array}{l}\text { Básico } \\
+3 \text { variáveis+1 } \\
\text { BVJ }\end{array}$ & $\begin{array}{r}\mathrm{R} \$ \\
224,00\end{array}$ & 3 & 1 & $\begin{array}{l}\text { Básico } \\
+3 \text { variáveis+1 } \\
\text { BVJ }\end{array}$ & $\mathrm{R} \$ 147,00$ \\
\hline 4 & 1 & $\begin{array}{l}\text { Básico } \\
+4 \text { variáveis+1 } \\
\text { BVJ }\end{array}$ & $\begin{array}{r}\mathrm{R} \$ \\
259,00\end{array}$ & 4 & 1 & $\begin{array}{l}\text { Básico } \\
+4 \text { variáveis+1 } \\
\text { BVJ }\end{array}$ & $\mathrm{R} \$ 182,00$ \\
\hline 5 & 1 & $\begin{array}{l}\text { Básico } \\
+5 \text { variáveis+1 } \\
\text { BVJ }\end{array}$ & $\begin{array}{r}\mathrm{R} \$ \\
294,00\end{array}$ & 5 & 1 & $\begin{array}{l}\text { Básico } \\
+5 \text { variáveis+1 } \\
\text { BVJ }\end{array}$ & $\mathrm{R} \$ 217,00$ \\
\hline $\mathbf{0}$ & 2 & Básico + 2 BJV & $\begin{array}{r}\mathrm{R} \$ \\
161,00\end{array}$ & 0 & 2 & Básico + 2 BJV & $\mathrm{R} \$ 84,00$ \\
\hline 1 & 2 & $\begin{array}{l}\text { Básico } \\
+1 \text { variável+2 BVJ }\end{array}$ & $\begin{array}{r}\mathrm{R} \$ \\
196,00\end{array}$ & 1 & 2 & $\begin{array}{l}\text { Básico } \\
+1 \text { variável+2 } \\
\text { BVJ }\end{array}$ & $\mathrm{R} \$ 119,00$ \\
\hline 2 & 2 & $\begin{array}{l}\text { Básico } \\
+2 \text { variáveis+2 } \\
\text { BVJ }\end{array}$ & $\begin{array}{r}\mathrm{R} \$ \\
231,00\end{array}$ & 2 & 2 & $\begin{array}{l}\text { Básico } \\
+2 \text { variáveis }+2 \\
\text { BVJ }\end{array}$ & $\mathrm{R} \$ 154,00$ \\
\hline 3 & 2 & $\begin{array}{l}\text { Básico } \\
+3 \text { variáveis+2 } \\
\text { BVJ }\end{array}$ & $\begin{array}{r}\mathrm{R} \$ \\
266,00\end{array}$ & 3 & 2 & $\begin{array}{l}\text { Básico } \\
+3 \text { variáveis+2 } \\
\text { BVJ }\end{array}$ & $\mathrm{R} \$ 189,00$ \\
\hline 4 & 2 & $\begin{array}{l}\text { Básico } \\
+4 \text { variáveis+2 } \\
\text { BVJ }\end{array}$ & $\begin{array}{r}\mathrm{R} \$ \\
301,00\end{array}$ & 4 & 2 & $\begin{array}{l}\text { Básico } \\
+4 \text { variáveis +2 } \\
\text { BVJ }\end{array}$ & $\mathrm{R} \$ 224,00$ \\
\hline 5 & 2 & $\begin{array}{l}\text { Básico } \\
+5 \text { variáveis }+2 \\
\text { BVJ }\end{array}$ & $\begin{array}{r}\mathrm{R} \$ \\
336,00\end{array}$ & 5 & 2 & $\begin{array}{l}\text { Básico } \\
+5 \text { variáveis+2 } \\
\text { BVJ }\end{array}$ & $\mathrm{R} \$ 259,00$ \\
\hline
\end{tabular}

Vale ressaltar que o valores médios dos benefícios do PBF, de acordo com cada região do território brasileiro, são:

\section{Quadro 5: valores médios repassados pelo Bolsa Família}

\begin{tabular}{|c|c|}
\hline \multicolumn{1}{|c|}{ Nível } & Valores \\
\hline Nacional & $\mathrm{R} \$ 164,86$ \\
\hline Centro-oeste & $\mathrm{R} \$ 150,76$ \\
\hline Nordeste & $\mathrm{R} \$ 170,41$ \\
\hline Norte & $\mathrm{R} \$ 187,99$ \\
\hline Sudeste & $\mathrm{R} \$ 151,31$ \\
\hline Sul & $\mathrm{R} \$ 147,42$ \\
\hline $\begin{array}{l}\text { Elaboração própria } \\
\text { Dados: MDS }\end{array}$ & \\
\hline
\end{tabular}

O PBF é um programa que possui condicionalidades correspondentes à matrícula e frequência escolar mínima de $85 \%$ para crianças e adolescentes entre seis e 15 anos; acompanhamento do calendário vacinal para crianças de até seis anos; pré-natal das gestantes em dia; acompanhamento de saúde da nutriz e do bebê, de meninas/mulheres entre 14 e 44 anos, e acompanhamento e ações socioeducativas para as crianças em situação de trabalho infantil. Se essas condições não forem cumpridas, pode haver 
suspensão e até desligamento da família. Existe um sistema só para as condicionalidades do PBF (Sicon).

O MDS avalia todo mês os níveis de qualidade dos cadastros da base nacional e faz o cruzamento dos dados do Cad-único com outros registros administrativos que possuem informações das pessoas, a saber: relação Anual de Informações Sociais (RAIS), base de dados do MTE; Cadastro Nacional de Informações Sociais (CNIS), gerido MPS; sistema Informativo de Controle de Óbitos, base do TSE e revisão cadastral anual.

Segundo dados disponibilizados pelo MDS, em seu sítio eletrônico, 13,9 milhões de famílias têm sua renda complementada pelo PBF, sendo este Programa responsável pela saída de 36 milhões de pessoas da extrema pobreza.

Com os avanços trazidos pela CF 88 e o novo cenário político, econômico e social brasileiro, a assistência necessitou, além de se redefinir, se afirmar na sociedade brasileira. Com isso se fez necessário criar, alterar e reavaliar os seus dispositivos legais.

Durante os governos petistas houve a criação de uma nova política socioassistencial, assim como a edificação do SUAS. Segundo Pereira (2007), houve mudanças consideráveis se se comparar com a antiga Política socioassistencial de 1998, com a nova de 2004, o que também demandou uma nova Norma Operacional.

As principais mudanças foram: "definição da política de assistência social como política de proteção social; delimitação das proteções que ela deve assegurar; territorialização da ação; instituição do Sistema Único de Assistência Social (SUAS); novas bases de financiamento" (p.70). No que tange à proteção, a autora lembra, que é sua obrigação garantir as seguranças de acolhida, sobrevivência e convívio, as quais estão guiadas pelos princípios de centralidade familiar, territorialização, proteção pró-ativa, integração a seguridade social e integração as políticas sociais e econômicas. No que tange à criação do SUAS, instituído em 2005, esta providência foi indicada na IV Conferência Nacional de Assistência Social, no ano de 2003. Em suas palavras esse sistema representa

nos termos da lei, um mecanismo organizador dos preceitos, disposições, ações e procedimentos previstos na LOAS e na PNAS. Seu objetivo é o de garantir, do ponto de vista operacional e em caráter sistêmico (funcionalmente interligados), a implementação e gestão da política (PEREIRA, 2007, p. 69). 
Outra mudança ocorrida nos referidos governos, foi a alteração da LOAS de 1993, por meio da Lei 12.435/ 2011, na qual para Cardoso (2011), teve como principais modificações a configuração da família e o conceito de deficiência. Esse conceito começou a ser pautado a partir de então, baseado na Convenção de Nova Iorque, na qual a definição de deficiência está colocada nos seguintes termos:

Pessoas com deficiência são aquelas que têm impedimentos de longo prazo de natureza física, mental, intelectual ou sensorial, os quais, em interação com diversas barreiras, podem obstruir sua participação plena e efetiva na sociedade em igualdades de condições com as demais pessoas (CONVENÇÃO DE NOVA IORQUE APUD CARDOSO, 2011).

Percebe-se, assim, uma melhora de vida no conjunto da população brasileira, na qual os principais feitos desses governos foram colocados anteriormente. Contudo, a análise que se segue pretende ser mais atenta em relação à dinâmica dessa melhora.

\subsection{Críticas aos pretensos avanços neodesenvolvimentistas no campo assistencial}

Inicia-se essa seção falando do crescimento do gasto social federal (visto no gráfico B), em especial no que se refere a assistência social.

Conforme análise de Castro (2012) constata-se que ocorreu um aumento de $172 \%$ em valores reais do Gasto Social Federal (GSF), entre 1995 e 2010, tendo esse crescimento se acentuado a partir do ano de 2004. Isso ocorreu, contudo, sem que se necessitasse aumentar substancialmente as parcelas do PIB, já que o país teve um crescimento econômico maior. O crescimento desse gasto em relação ao PIB foi de 4,3\% (1995-2010); mas, esse crescimento se deu, como ressalta o autor, com um caráter anticíclico ante os impactos da crise mundial. O gráfico abaixo mostra que o GSF era anteriormente pró-cíclico, ou seja, à medida que o PIB diminuía havia uma retração quanto aos recursos destinados ao GSF. Isso ocorreu nas crises de 1998-1999, 2002-2003, mas, em 2008-2009, o movimento foi justamente o contrário: o PIB desacelerou e o GSF acelerou, como indica o gráfico I. 
GRÁFICO I: Taxas de crescimento real do GSF e do PIB- em períodos de crise

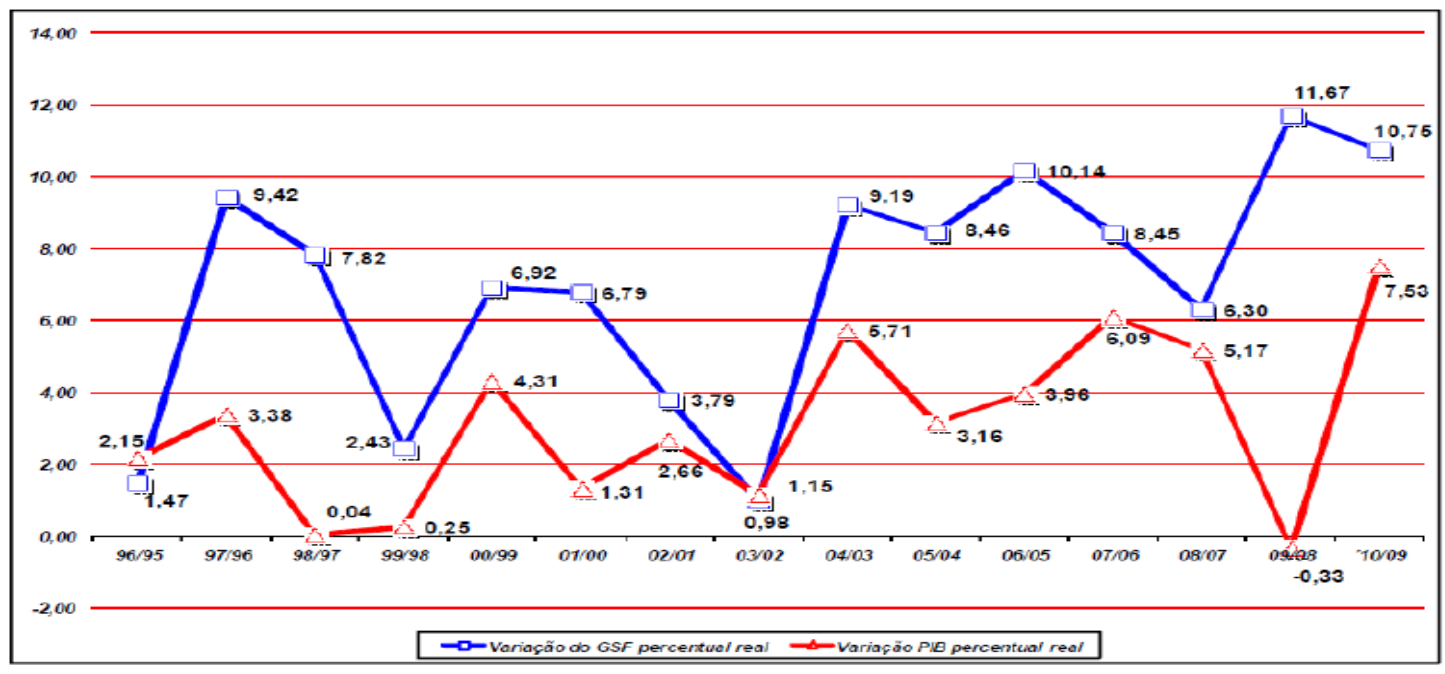

Fonte: Castro (2012). Nota técnica - Gasto Social Federal: prioridade macroeconômica no período 1995-2010. IPEA Set. 2012.

Em relação à assistência social, esta política, como já salientado (vide gráfico C), cresceu em relação á destinação de seus recursos. Segundo Castro (2012), esta destinação multiplicou-se por 13 entre os anos de 1995-2010. Contudo, esse montante representa somente $1 \%$ do PIB, vide gráfico J, donde se conclui que, dentro do GSF tal destino é de apenas 1/15, o que é preocupante porque esses dados são advindos de uma trajetória crescente dessa política, ao mesmo tempo em que foi utilizada para atenuar os impactos da crise, ou seja, os custos sociais advindo da mesma; e mesmo assim, essa é a destinação máxima de recursos que se tem.

\section{GRÁFICO J: GSF por área de atuação}

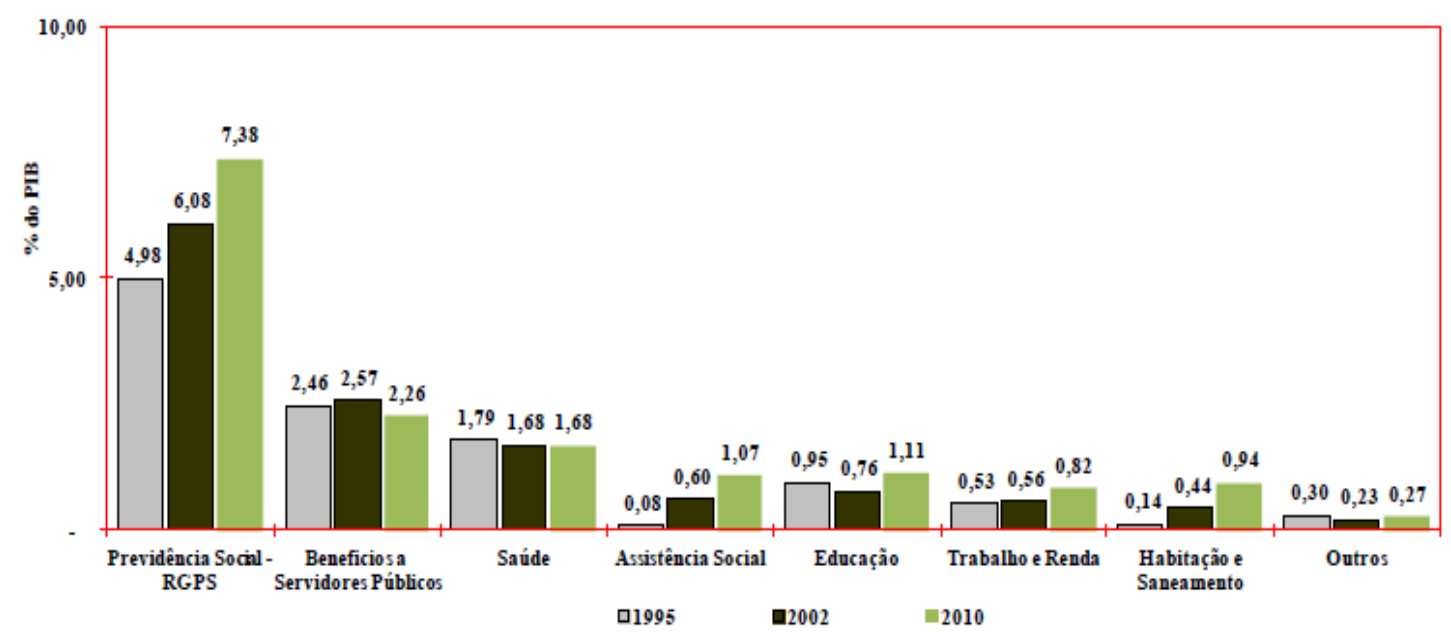

Fonte: Castro (2012). Nota técnica - Gasto Social Federal: prioridade macroeconômica no período 1995-2010. IPEA Set. 2012.

Existe, nesse contexto específico, a retomada da afirmativa veiculada internacionalmente, desde os 1980, no rastro da expansão triunfante das políticas sociais 
neoliberais, de que esse crescimento da política socioassistencial representa uma assistencialização da Seguridade Social (MOTA, 2008). Entretanto, se por assistencialização entender-se o predomínio da política de assistência social sobre as demais políticas sociais públicas, dentro da arquitetura do projeto neodesenvolvimentismo brasileiro, esse discurso não confere, nem se ele levar em conta, apenas, a variável financiamento; isso porque, mesmo havendo aumento de recursos para a assistência social, no âmbito da Seguridade Social, esta política é a que menos recebe repasse (vide gráficos D e E.) e a que utiliza 90\% dos recursos recebidos em atividades declaradamente consideradas de alivio da pobreza, o que, na realidade, configura uma desassistencialização da própria política que pretendente ser socioassistencial.

No que tange à redução da desigualdade social, vale a pena ainda reafirmar que essa redução ocorreu na pobreza extrema e mesmo assim de forma residual. Tanto isso é verdade, que o Brasil continua, ainda, um dos países mais desiguais do mundo ${ }^{12}$ (vide mapa que se segue). Segundo o IPEA (2013), a renda do $1 \%$ mais rico cresceu $16,1 \%$ e a dos $5 \%$ mais ricos cresceu 9,4 , ao passo que os $5 \%$ mais pobres aumentaram sua renda em 20\%, apesar de, aparentemente, isso representar um avanço. Se essa diferença fosse colocada em valores $\mathrm{R}$ \$ ter-se-ia, de forma mais visível, uma discrepância mais que absurda dessas rendas, chegando a ser irônico que o crescimento de $20 \%$ da renda desses $5 \%$ mais pobres foram suficientes somente para que os mesmos saíssem da situação de indigência. Assim, se a extrema pobreza, ou mesmo a pobreza, diminuíram, isso não aconteceu de maneira a modificar a estrutura da desigualdade social no país. Os ricos, especialmente os banqueiros, foram os mais beneficiados pela política neodesenvolvimentista dos últimos 12 anos.

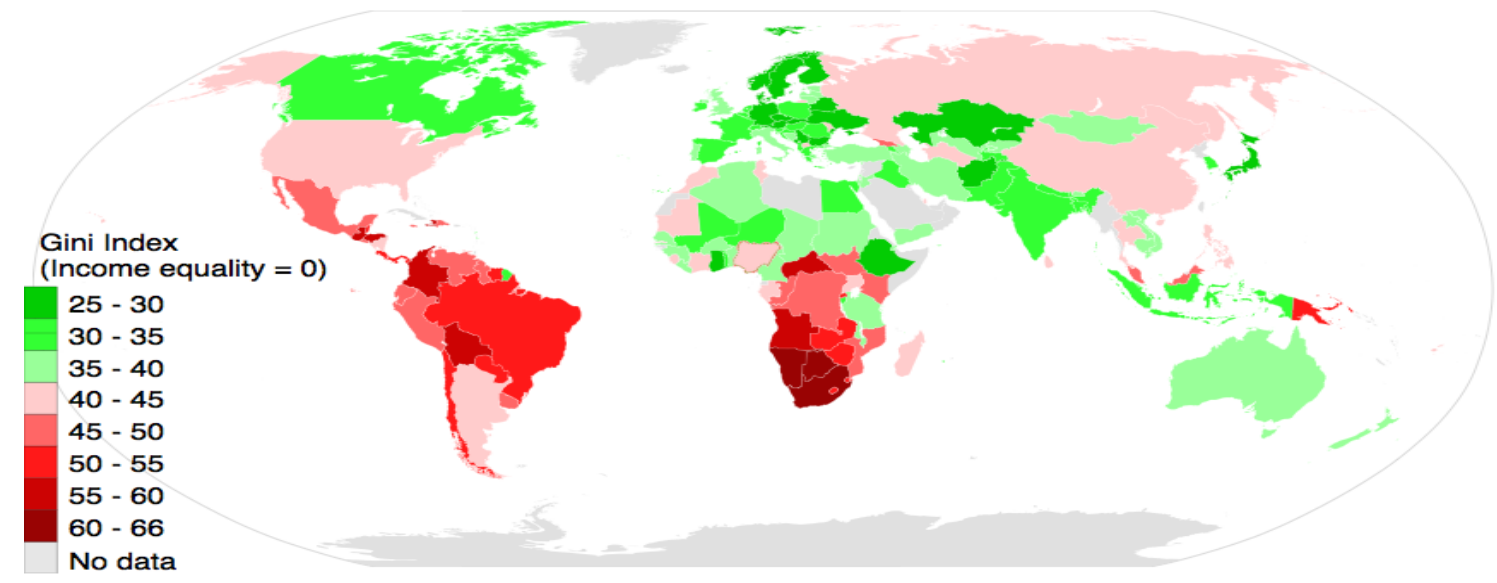

Fonte: Banco Mundial (2014)

${ }^{12}$ Ver anexo IV lista específica com valores e colocações no âmbito mundial. 
O crescimento que vem ocorrendo na assistência se dá via programas de transferência de renda com priorização de políticas focalizadas. Segundo Mauriel (2012), essa forma com que vem se orquestrando a política socioassistencial- na prática voltada para os pobres, acaba por afastar a política da concepção de seguridade social, o que, consequentemente, impacta sobre o seu status de política pública, dificultando a generalização dos direitos sociais.

Essa estratégia de combater à pobreza como algo central nas políticas socioassistenciais, não é uma característica somente brasileira, muito pelo contrário. Está em curso mundialmente. Segundo Mauriel (2012), essa tendência vem sendo crescente desde os anos 1980, no período de queda do welfare state, no qual

o papel estratégico que o conjunto de ações de combate a pobreza possui hoje para a manutenção do atual padrão de acumulação via financeirização caracteriza-se pela regulação dos custos da força de trabalho no mercado mundial, por meio da regulação do comportamento econômico, político e civil dos pobres, garantindo baixo risco de sublevação social e uma forma ideologicamente palatável de inserção precária dessas massas na ordem econômico-financeira contemporânea (MAURIEL, 2012, p. 185-186).

As recomendações dos organismos internacionais possuem, como norte, apenas o alívio da pobreza, o que, para Fagnani (2011), é gravíssimo, pois se utiliza de fórmulas neoliberais para lutar contra as consequências da adesão ao neoliberalismo. E, como se sabe, essas recomendações não bastam, para se alcançar o bem-estar social, que passou a ser medido pelo indicador de pobreza de US\$2,00 dia, indicador esse que continua a ser referência, inclusive no Brasil, mesmo depois da evidência dos custos sociais advindos da adesão a esse padrão de acumulação.

Fagnani (idem) ressalta ainda que o fato de o país ter atingido o primeiro objetivo de desenvolvimento do milênio, no prazo de 6 anos, contra os 25 anos propostos, passou a ser considerado um case e a ser usado como exemplo, a ponto de se exportar o modelo do PBF para outros países, por consideram-no o possibilitador único da redução da pobreza e da extrema pobreza. Nas palavras do autor,

esse equívoco parece prestar-se a objetivos ideológicos muito bem delineados: transformá-lo num case internacional de sucesso. Essa estratégia parece ser útil para convencer acerca das virtudes da iniciativa do Piso de proteção social (p. 24). 
Ainda segundo Fagnani (Idem), existe uma mistificação em torno desses programas e de sua real importância. No caso brasileiro, constitui um absurdo não se levar em consideração os vários fatores que recaem sobre essa redução da pobreza, como o aumento real do salário mínimo, ampliação do mercado de trabalho, transferências monetárias da Seguridade Social - em especial a previdência rural, na qual não há desembolso por parte do beneficiário, etc. Ou seja, há segundo ele, uma visão reducionista da realidade do país, donde conclui que o caso brasileiro tem destaque dos organismos internacionais, visto a sua efetividade, isto é, a alta cobertura de beneficiários com custo baixíssimo em \% do PIB. Tanto é assim que, no relatório da OIT (2011), o PBF é apresentado como um Programa com requisitos, leia-se com condicionalidades, baixo custo, e com

esforços para a inclusão dos beneficiários no mercado de trabalho através do desenvolvimento de competências e de outras políticas de emprego [...] Inclui igualmente medidas para facilitar a inclusão produtiva, tais como serviços de apoio à busca de emprego, formação profissional e microcrédito (OIT, 2011, p. 50)

Nas palavras de Pereira (2013), este

é um expediente tecnocrático [...] para diminuir artificialmente a pobreza e a desigualdade e, por consequência, o montante de demandantes credenciados ao acesso a políticas sociais, agora focalizadas (p. 640).

Efetivamente, está-se diante de um direcionamento mundial da política socioassistencial sob o comando do neoliberalismo; e, apesar da particularidade histórica brasileira e do discurso neodesenvolvimentista, também no Brasil esse direcionamento se consagrou e se tornou hegemônico. Segundo a referida autora, existe um número considerável de pessoas que reproduzem, muitas vezes sem sentir, mantras liberais que fortalecem o poder do capital sobre as políticas sociais; e na base desses mantras ressalta o argumento de que não há melhor fonte de bem-estar humano do que o trabalho (p.640). Assim, quanto mais a política social se distancia dessa prédica, e mais se mercadoriza, menos ela é benquista pelo sistema. Tem-se, assim, no presente, o retorno de medidas de desserviço à proteção social pública, resgatadas lá da Lei dos Pobres inglesa, de 1834, e que são contempladas sobremaneira no PBF, a saber:

a) A distinção conceitual entre pobreza e indigência, para focalizar a assistência pública nos mais pobres entre os pobres; b) A ativação compulsória dos pobres capazes de trabalhar para atividades produtivas, remuneradas, geralmente providenciadas pelo próprio estado; c) A instituição dos testes de meios ou as famigeradas 
comprovações de pobreza para selecionar os merecedores da ajuda pública dos não merecedores; d) A adoção de condicionalidades e do princípio da menor elegibilidade de acordo com a qual o valor monetário dos benefícios sociais terá de ser menor do que o pior salário (PEREIRA, 2013, p. 643).

O PBF, como um programa de governo e não propriamente parte inviolável da política pública socioassistencial, faz com que o mesmo não se configure como um direito social e, portanto, pode deixar de existir se essa for a vontade dos governantes. Segundo Boito (2012b), os seus beneficiários, denominados pelo autor de "massa pauperizada",

não intervém de forma organizada na frente política neodesenvolvimentista. Os governos Lula e Dilma optaram por lhe destinar renda sem se preocupar - nem esses governos, nem o seu partido, o PT - em organizá-los. Eles formam uma base eleitoral desorganizada e passiva que é convocada a intervir no processo político apenas por intermédio do voto para sufragar os candidatos da frente neodesenvolvimentista (p. 10-11).

A isso, pode-se acrescentar que, mesmo a assistência social sendo, em tese, uma política pública, de seguridade social, a utilização de programas de governo como esse, reforçam uma característica historicamente nefasta do Brasil: clientelismo e paternalismo que, nas palavras de Neves (2008) estão entranhados na cultura política nacional e tencionam os esforços pela democratização do Estado brasileiro.

O PBF tem, em sua base, um evidente e insofismável caráter liberal, marcado pela busca incessante - como fim e não como meio - da: eficiência, eficácia e efetividade, signos de sua racionalidade referenciada na rentabilidade econômica privada. Percebe-se na análise dos efeitos do PBC, o uso demasiado de indicadores, como por exemplo: os Indicadores de Condicionalidades do Programa, são aproximadamente 140. Segundo Mauriel \& Rais (2013), este abuso da utilização de indicadores é preocupante, pois eles estão ganhando legitimidade ampliada e se sobrepõem a verdadeira aferição do bem-estar da população. Como afirmam as citadas autoras, esses indicadores têm a sua serventia analítica, mas “não são suficientes para construção de qualquer solução pública” (p.134).

Somado ao seu caráter liberal, está o fato de que, tanto o monitoramento quanto a fiscalização do Programa Bolsa Família, realizados pelo governo federal, está tendo muito dispêndio, o que certamente subtrai recursos que poderiam ser empregados em atividades-fim. O monitoramento dos beneficiários é feito, em grande medida, para verificar se está havendo omissão ou subdeclaração de renda por parte dos mesmos, via MTE por meio de informações de pessoas com vínculo CTPS ou contrato de trabalho; via 
CNIS por meio de informações de pessoas que recebem benefícios previdenciários ou que contribuam; via TSE por meio de informações de pessoas que ocupem cargo eletivo. Já a fiscalização, apesar de ser voltada para o Programa em si, também incide sobre os beneficiários, quando se "chama" o cidadão para realizar denúncias sobre possíveis irregularidades, entendidas, principalmente, como recebimento indevido do benefício. $\mathrm{E}$ tudo isso é realizado como controle da distribuição de valores irrisórios, vide quadros $4 \mathrm{e}$ 5 , que não chegam a atender minimamente as necessidades vitais dessas famílias, as quais "vêm sendo ostensivamente rebaixadas ao nível bestial de sobrevivência animal" (PEREIRA, 2013, p. 640).

Por traz da escolha brasileira em priorizar os Programas de transferência de renda, em detrimento da oferta pública e de qualidade de serviços socioassistenciais está também a ideia de emulação do indivíduo consumidor que contraria a visão de sujeitos de direitos. E, assim, a política pública de assistência social

se degrada por sua dupla qualificação perversa: como relief (alívio da pobreza) e como agenciadora de força de trabalho pouco qualificada para o mercado de trabalho e de consumo de massa. E, nesse sentido, ela constitui um desserviço público e, portanto, não assiste (PEREIRA, 2013, p. 649). Grifo acrescentado.

O problema, portanto, não é a política de assistência social brasileira dar atenção à pobreza, mas a forma como isto vem se realizando. No seu processamento predomina a sua despolitização e transformação em assunto técnico que desconsidera questão estrutural da desigualdade e da pobreza, sendo o combate de ambas relegado a segundo plano, para não dizer, "esquecido". A política de assistência se apresenta como se tivesse apenas como público-alvo os pobres, e estes "são renomeados por suas fragilidades, descontextualizados, des-historicizados, aparecendo no discurso tecnocrático reconstituídos por um novo tipo de vigilância moral” (MAURIEL, 2012, p.181).

A última mudança na política de assistência social vai ao encontro dessa tendência, se distanciando dos seus aspectos fundamentais de outrora. A nova Lei 12.435/2011 altera a LOAS e a transforma no SUAS; a preocupação com a pobreza "deixa de ser um objetivo e passa a ser o principal motivo de existência da assistência social" (MAURIEL, 2012, p. 190). Assim,

A "nova" concepção de Assistência, como a própria PNAS afirma, corrobora com os princípios e conceitos presentes na teoria do desenvolvimento humano ou desenvolvimento com liberdade de 
Amartya Sen, base que fundamenta os documentos dos organismos multilaterais como Banco Mundial e Programa das Nações Unidas para o Desenvolvimento (PNUD) e Organização Mundial do Comércio (OMC) (MAURIEL, 2012, p. 190).

É de suma importância ressaltar a escolha da família pelo Programa e pela política, pois esta é uma escolha complexa e contraditória. Afinal, a família é chamada a ser protegida ao mesmo tempo em que é responsabilizada pela situação de pobreza em que se encontra. Vê-se ai a disputa entre o projeto neoliberal e o democrático. Segundo Pereira (2004), a família vem sendo "redescoberta" como agente privado de proteção social em substituição ao Estado, dentro de um modelo de proteção social denominado plural no qual aos poucos foi trazendo a família para berlinda. Ou seja, a proteção da família está ocorrendo de forma residual, já que ela é chamada a ser protegida, mas o Estado burguês está intervindo apenas quando a família não consegue a sua autossustentabilidade. Por conseguinte, a priorização dos programas de transferência monetária de renda, tem, por consequência, a desassistencialização da política, já que está fica em segundo plano, para não dizer em último, enfraquecendo a luta contra hegemônica por efetivação de direitos, além de dificultar a materialização deste. Contudo, contraditoriamente, segundo Mioto (2008), a CF vigente traz uma visão diferenciada, pois chama a família para o centro, com vistas a tentar garantir seus direitos. E assim,

Considerando que nem a sociedade e nem o Estado são blocos monolíticos e que as relações estabelecidas nesses âmbitos são contraditórias e expressam conflitos existentes entre diferentes concepções de proteção social, a questão da centralidade da família passa a ocupar um lugar importante no confronto entre os diferentes projetos. Projetos que buscam colocar em movimento estratégias sóciopolíticas diferentes e que disputam a hegemonia tanto no plano da direção política de seus formuladores, quanto nos espaços de gestão e execução das políticas públicas. Tanto naquelas que mantém o seu caráter de universalidade, quanto naquelas de caráter focalizado (MIOTO, 2008, p.141-142).

Diante desse quadro, conclui-se que a assistência social se reestruturou, mas continuou com seu núcleo liberal. Nas considerações de Pereira (2013),

se antes [ela] era considerada um colchão protetor de possíveis resvalos dos mais pobres para abaixo de uma linha de pobreza oficialmente arbitrada, hoje ela funciona como um trampolim, na concepção do Banco Mundial, cuja principal tarefa é ativar os pobres para fora de seu âmbito rumo a sua autossustentação. (...) Isso porque, a proteção social nunca esteve, como agora, tão associada ao trabalho assalariado, à renda, ao mérito associado ao poder de consumo, ao consumo 
conspícuo, a lógica comercial e, por isso, nunca esteve tão distanciada da proteção social como direito devido e desmercadorizado (PEREIRA, 2013, p. 650).

Portanto, pode-se dizer que a assistência social, sob o lema neodesenvolvimentista, melhorou a vida de um considerável contingente de usuários da política; contudo esta "melhora" está pautada no mínimo social, ao nível de sobrevivência humana, e "de provisão social residual, arbitraria e elitista" (p. 16) que, segundo Pereira (2008), negligenciam as necessidades humanas. Isto, por sua vez, "permite a inferência de que níveis superiores e concertados de satisfação devem ser perseguidos” (p. 181)

Isso quer dizer que a assistência social deve ser concebida e trabalhada como uma política social pública, tanto em sua fundamentação quanto em sua materialização cotidiana; e mais, como produto histórico inscrito em uma realidade complexa e dinâmica. Dessa forma, a luta se dá de forma contra hegemônica; deve-se buscar a materialização da mesma como um direito social a ser garantido pelo Estado, com vistas a combater concepções restritivas, mas sem esquecer que a batalha por emancipação política direciona-se no sentido da emancipação humana, que só se dará para além do sistema do capital. 


\section{A MODO DE CONCLUSÃO}

Do que foi exposto nesta Dissertação é possível fazer deduções gerais, ficando a certeza de não ser possível apreender a política socioassistencial em sua completude, sem considerar as suas ligações e imbricamentos com outras esferas da vida econômica, política e social.

Buscou-se aqui apreender o movimento da política socioassistencial e suas condições objetivas e subjetivas no contexto das relações recíprocas e antagônicas ao mesmo tempo, entre Estado e sociedade na contemporaneidade brasileira; uma contemporaneidade marcada pela peculiaridade governamental de pretender resgatar o projeto desenvolvimentista dos anos trinta a cinquenta do século passado em meio à crise global do capital e à hegemonia mundial da ofensiva neoliberal, negadora dos direitos sociais.

Verificou-se o predomínio agudo de um momento de crise estrutural e sistêmica que se alastrou, desde os fins dos anos 1970, pelo mundo inteiro e abalou, especialmente a partir de 2008, o funcionamento do modo de produção capitalista, cujos altos e baixos cíclicos corriqueiros, porque inerentes a esse modo de produção, cederam lugar a um processo crítico duradouro. Os impactos negativos desta crise recaem também, como não poderia deixar de ser, sobre a nação brasileira, na qual seus governantes dos últimos doze anos, pautados por uma governança supostamente "neodesenvolvimentista" e socialmente includente, adotaram estratégias que tiveram sucesso temporário e epidérmico. Dentre as estratégias de combate à referida crise inclui-se o uso de uma política socioassistencial centrada na melhoria da renda dos segmentos mais pobres da população, e na sua capacidade de consumo. E isso, obviamente, favoreceu muito mais o mercado do que o cidadão pobre, então transformado em consumidor, até porque a renda obtida via programas governamentais não diminuiu a desigualdade a que estavam submetidos.

Para a constituição de um pano de fundo teórico e histórico analisou-se as diferenças nacionais entre o passado desenvolvimentista e o pretendido presente "novo"(neo) desenvolvimentista, com vistas a desmistificar o retorno daquele, que se sustentou em argumentos incapazes de refletirem a realidade. Nesta, prevaleceu a 
sucumbência dos governos neodesenvolvimentistas aos ditames neoliberais, que são os verdadeiros determinantes dos programas focalizados de transferência de renda adotados contemporaneamente no Brasil.

Contudo, tais iniciativas, que se deram por meio de uma estratégia de fuga para frente, lograram alguns êxitos no governo Lula, que começaram a se esvanecer no primeiro governo de Dilma. Pode-se dizer, portanto, que a chegada ao poder pelo Partido dos Trabalhares (PT), ao qual Lula e Dilma representam, foi marcada por uma operacionalidade liberal, frustrando, assim, as expectativas contrárias dos que acreditavam que os ventos tomariam outros rumos. Presenciou-se uma regressão política tendo em vista a origem do Partido ligada ao movimento operário, que em vez de defender reformas estruturais, manteve-se preso ao horizonte da hegemonia burguesa, trabalhando no viés da "colaboração de classe". Se verificou que tanto os ganhos quanto as perdas se deram de maneira desigual entre as classes sociais brasileiras, em pese a classe trabalhadora e os pobres em geral terem obtido ganhos marginais.

Quanto à condução da política socioassistencial, pode-se dizer que houve ressignificações. Mas, estas, ficaram mais no discurso, favorecendo, apenas, sutis melhoras de vida dos segmentos pobres da população que aconteceram sem alterar a base da estrutura de classe e erradicar as ainda profundas disparidades sociais. Ou seja, o pacto interclassista defendido pelo PT, a conciliação dos interesses antagônicos sederam de maneira a atender supremacia das necessidades do capital em detrimento do atendimento das necessidades humanas. Constata-se, que da maneira como está se configurando a política de assistência, esta vai na contramão da garantia desse direito e ao encontro da focalização da pobreza; e isso gera estigmatização do pobre, ativação, muitas vezes forçada e punitiva desse segmento social para o mercado de trabalho flexível e precário; refamilização da política e fortalecimento da ideia do cidadão consumidor. $\mathrm{O}$ mínimo ganha espaço nessa garantia em vez sequer do atendimento básico. E o país segue com suas relações próximas aos organismos internacionais, em outras palavras, aos defensores da barbárie social.

Vislumbra-se, que, a consolidação da assistência social no Brasil enquanto política pública e direito social está intimamente ligada a resistência e a luta contra hegemônica que se opera no país, que apesar da conjuntura desfavorável e seu histórico passado, ainda intenta-se materializar referenciada nos avanços constitucionais. Afinal, 
como diz Coutinho (2008), “os direitos são os que permitem ao cidadão uma participação mínima na riqueza material e espiritual criada pela coletividade” (p. 63)

Contudo, entende-se que o caminho para a emancipação humana não está nos limites da ordem capitalista; afinal acredita-se que a história está em aberto e a busca pela socialização da riqueza não esmoreceu. Essa luta é cotidiana, rumo a uma nova sociabilidade. 


\section{REFERÊNCIAS}

ALMEIDA, L. F. R. Entre o nacional e o neonacional desenvolvimentismo: poder político e classes sociais no Brasil Contemporâneo. In: Serviço Social e Sociedade. $N^{\circ}$ 112, Cortez, 2012.

ALVES, R. Filosofia da ciência: introdução ao jogo e suas regras. SP: Edições Loyola, 2011.

ANDERSON, P. Balanço do Neoliberalismo. In: SADER; GENTILI (Orgs.). Pósneoliberalismo: as políticas sociais e o Estado democrático. 4. Ed. São Paulo: Paz e Terra, 1995.

ANTUNES, Ricardo. Apresentação. In: MÉSZÁROS, I. Para além do capital. São Paulo: Boitempo, 2011.

BEHRING E. Desigualdade e Política Social no "Neodesenvolvimentismo" Brasileiro. Texto Inédito (texto disponibilizado pela autora).

Fundamentos da política social. In: Serviço Social e Saúde: formação e trabalho profissional. SP: Ed. Cortez, 2008.

Política social no contexto da crise capitalista. In: Serviço Social: Direitos Sociais e Competências Profissionais. Brasília: CFESS/ ABEPSS, 2009.

BOBBIO, N. Liberalismo e democracia. SP: Ed. Brasiliense, 2013.

BOITO Jr., A. Entrevista dado ao jornal Brasil de Fato. Em 2012. Disponível em: http://www.brasildefato.com.br/content/\%E2\%80\%9C-economia-capitalistaest $\% \mathrm{C} 3 \% \mathrm{~A} 1$-em-crise-e-contradi\%C3\%A7\%C3\%B5es-tendem-seagu $\%$ C3\% A 7 ar\%E2\%80\%9D SP, 2012b.

As bases políticas do neodesenvolvimentismo. In: Fórum Econômico da FGV,

BOSCHETTI, I. A insidiosa corrosão dos sistemas deproteção social europeus. In: Serviço Social e Sociedade. N 112, Cortez, 2012.

Políticas de desenvolvimento econômico e implicações para as políticas sociais. In: Ser Social, v. 15 n³3, 2013.

BOSCHETTI \& BEHRING. Política Social: fundamentos e história. SP. Cortez: 2008.

Política de desenvolvimento econômica e implicações para políticas sociais. In: Ser Social v. 15, n. 33. Brasília, 2013.

CABRERO, G. R. In: Economia Política del Estado del bienestar. Madrid: Blume ediciones, 1982. 
CARCANHOLO, M. Neoconservadorismo com roupagem alternativa: a nova Cepal dentro do Consenso de Washington. In: encruzilhadas da América Latina no século XX. Ed. Pão e Rosas, 2010.

CASTELO, R. O novo desenvolvimentismo e a decadência ideológica do pensamento econômico brasileiro. In: Serviço Social e Sociedade. No 112, Cortez, 2012.

O novo-desenvolvimentismo e a decadência ideológica do estruturalismo latino americano. In: encruzilhadas da América Latina no século XX. Ed. Pão e Rosas, 2010.

O social-liberalismo: auge e crise da supremacia burguesa na era neoliberal. SP: Ed. Expressão Popular, 2013.

CASTRO, J. Gasto Social Federal: prioridade macroeconômica no período 1995-2010. Nota técnica Disoc- IPEA, 2012.

COUTINHO, C. N. Contra a Corrente. Ensaios sobre democracia e socialismo. São Paulo: Cortez, 2008.

COUTO, B. O direito social e a assistência social na sociedade brasileira: uma equação possível? SP: Cortez, 2010.

FAGNANI, E. Seguridade Social: a experiência brasileira e o debate internacional. In: Análises e propostas. Friedrich Ebert Stiftung, 2011.

FONTES, V. Imperialismo e crise. In: Capitalismo em crise: a natureza e dinâmica da crise econômica mundial. SP, ed. Instituto José Luis e Rosa Sudermann, 2009.

FONSECA, P.C.D; CUNHA, A M. \& BICHARA, J. S. O Brasil na era Lula: retorno ao desenvolvimentismo? Rede desenvolvimentista, 2012.

GRABOIS, I. Classes e frações de classe no segundo governo Dilma. 2014. Disponível em:http://marxismo21.org/wp-content/uploads/2014/11/Classes-

fra\%C3\%A7\%C3\%B5es-no-segundo-governo-Dilma-I-Grabois.pdf

GRESPAN, J. Uma teoria para as crises. In: Capitalismo em crise: a natureza e dinâmica da crise econômica mundial. SP, ed. Instituto José Luis e Rosa Sudermann, 2009.

GONÇALVES, R. Novo desenvolvimentismo e liberalismo enraizado. In: Serviço Social e Sociedade. No 112, Cortez, 2012.

Governo Lula e o nacional desenvolvimentismo às avessas, 2011. Disponível em: $<\mathrm{http}: / /$ www.ie.ufrj.br/hpp/intranet/pdfs/texto_nacional_desenvolvimentismo_as_avessas_14_0 9_11_pdf.pdf>. 2011.

HAGUETTE, Teresa M. F. Metodologias qualitativas na Sociologia. Petrópolis/RJ: Vozes, 2003. 
HARVEY, D. O neoliberalismo: história e implicações. São Paulo: Edições Loyola, 2012.

Condição Pós-moderna. São Paulo: Edições Loyola, 2012b.

HEYWOOD, A. Ideologias políticas: do liberalismo ao fascismo. SP: Ed. Ática, 2010.

HOBSBAWM, E. Era dos Extremos: o breve século XX: 1914-1991. São Paulo: Companhia de Letras, 1995.

IANNI, O. A era do globalismo. Rio de Janeiro: Civilização Brasileira, 2011.

A crise de paradigmas na Sociologia, Revista Crítica das Ciência Sociais $\mathrm{n}^{\mathbf{0}} 32$, jun. de 1991, 195-215. Disponível em: < http://poderedesenvolvimento local.files.wordpress.com/2011/02/octavio_ianni_a_crise_de_paradigmas_na_sociolog ia.pdf > . Acesso em 16 de março de 2013

IPEA, Mudanças recentes na pobreza brasileira. Comunicado №111, 2011.

A década Inclusiva (2001-2011): Desigualdades, pobreza e políticas de renda. Comunicados $\mathrm{N}^{\mathrm{o}}$ 155, 2012.

$N^{o} 159,2013$.

Duas décadas de desigualdade e pobreza no Brasil medidas pela PNAD/IBGE.

MACIEL, D. De Lula a Dilma: crise econômica, hegemonia neoliberal e regressão política. 2012. Disponível em: http://marxismo21.org/wp-content/uploads/2013/06/DMaciel-2.pdf

MANDEL, E. O capitalismo tardio. São Paulo: Abril Cultural, 1982.

A crise do capital: os fatos e sua interpretação marxista. SP, ed. Ensaio, 1990.

MARINI, R. M. Subdesenvolvimento e revolução. Florianópolis: Editora Insular, 2012.

A crise do desenvolvimentismo. In: encruzilhadas da América Latina no século XX. Ed. Pão e Rosas, 2010.

MARSIGLIA, R. M. G. Orientações básicas para a pesquisa. In: Serviço Social e saúde: formação e trabalho profissional. São Paulo: OPAS, OMS, Ministério da Saúde, 2006.

MARX\&ENGELS. Manifesto do Partido Comunista. RJ, ed. Zahar, 2006.

MATTEI, L. Gênese e agenda do novo desenvolvimentismo brasileiro. In: Revista de economia política, vol. 33, nº 1, 2013.

MAURIEL\& RAIS. 2013 Indicadores de pobreza nas políticas sociais brasileiras. In: R. Pol. Públ., v.17, n.1, p. 127-137, 2013. 
MAURIEL, A.P. Pobreza, seguridade e assistência social: desafios da política social brasileira. In: Desenvolvimento e construção da hegemonia: crescimento econômico e reprodução da desigualdade. São Paulo: Cortez, 2012.

MÉSZÁROS, I. A crise estrutural do capital. São Paulo: Boitempo, 2009.

Para além do capital. São Paulo: Boitempo, 2011.

MINAYO \& SANCHES. Quantitativo-qualitativo: oposição ou complementaridade? Cad. Saúde Pública. V.9. RJ, 1993.

MIOTO, R. T. Família e políticas sociais, In BOSCHETTI, Ivanete... (Orgs.). Política social no capitalismo: tendências contemporâneas. São Paulo: Cortez, 2008, p. 130-148.

MONTAÑO, C \& DURIGUETTO M. L. Estado, Classe e Movimento Social. Biblioteca Básica/ Serviço Social. SP: Ed. Cortez, 2011.

MOTA. A. E. O mito da Assistência Social: ensaios sobre Estado Política e Sociedade. SP: Cortez, 2008.

MOTA, AMARAL \& PERUZO. O novo desenvolvimentismo e as políticas sociais na América Latina. In: Desenvolvimentismo e Construção de Hegemonia: crescimento econômico e reprodução da desigualdade. SP: Cortez, 2012.

NETO, E. A. Uma onda longa recessiva está apenas começando. In: Capitalismo em crise: a natureza e dinâmica da crise econômica mundial. SP, ed. Instituto José Luis e Rosa Sudermann, 2009.

NETO, J. M. B. Os governos do PT: poucas mudanças, nenhuma ruptura. Junho, 2013. Disponível em: http://marxismo21.org/wp-content/uploads/2013/06/J-Machado.pdf

Governo Lula: uma opção neoliberal. In: Adeus ao desenvolvimento: a opção do governo Lula. Belo Horizonte: Autêntica, 2005.

NEVES, A. Cultura Política e Democracia Participativa: um estudo sobre o orçamento participativo. Gramma, RJ, 2008.

OIT. Piso de proteção social para uma globalização equitativa e inclusiva. Relatório do grupo consultivo sobre o piso de proteção social. Genebra, 2013.

OLIVEIRA, F. Hegemonia às avessas: economia, política e cultura na era da servidão financeira. São Paulo: Boitempo, 2010.

PAULA. J. A. Apresentação. In: Adeus ao desenvolvimento: a opção do governo Lula. Belo Horizonte: Autêntica, 2005.

PEREIRA, P. A. P. Necessidades Humanas: subsídios à crítica dos mínimos sociais. São Paulo: Cortez, 2008. 
A assistência social na perspectiva dos direitos: críticas aos padrões dominantes de proteção aos pobres no Brasil. Brasília: Thesaurus, 1996.

A assistência social prevista na Constituição de 1988 e operacionalidade pela PNAS e pelo SUAS. In: Ser Social, no 20, 2007.

Mudanças estruturais, política social e papel da família: crítica ao pluralismo de bem-estar. In: Política social, família e juventude. São Paulo: Cortez, 2004.

Política social: temas \& questões. SP: Cortez, 2008b. SP, 2013.

Proteção social contemporânea: cui prodest? In: Serv. Social e Sociedade. No 116.

Sobre a política de assistência social no Brasil. In: Política social e democracia. SP: Cortez, 2012b.

Utopias desenvolvimentistas e política social no Brasil. In: Serviço Social e Sociedade. N $^{\mathrm{o}}$ 112, Cortez, 2012.

PINHEIRO, M. O governo petista como operador político da burguesia no Brasil. 2013. Disponível em: http://marxismo21.org/wp-content/uploads/2013/06/M-Pinheiro.pdf

POMAR, W. Esquerdas, PT, Dilma e projeto de reformas. Setembro, 2014. Disponível em: http://marxismo21.org/wp-content/uploads/2014/09/Wladimir-Pomar-dossie.pdf

PRADO, F. \& MEIRELES, M. Teoria marxista da dependência revisitada: elementos para a crítica ao novo-desenvolvimentismo dos atuais governos de centro-esquerda latino-americanos. In: encruzilhadas da América Latina no século XX. Ed. Pão e Rosas, 2010.

RAICHELIS, R. Serviço social e saúde: formação e trabalho profissional. SP: Cortez, 2006.

SISCÚ, PAULA \& MICHEL. Por que um novo desenvolvimentismo? In: Jornal dos economistas, $\mathrm{n}^{\circ} 186$, jan. 2005.

SADER, E. A construção da hegemonia pós-neoliberal. In: Lula e Dilma: 10 anos de governos pós-neoliberais no Brasil. Rio de Janeiro: FLACSO e Boitempo, 2013.

SALUDJAN, A. Estratégias de desenvolvimento e inserção da América Latina na economia mundial. Os estruturalistas e neoestruturalistas da Cepal: uma abordagem crítica. In: Encruzilhadas da América Latina no século XXI, RJ: Ed. Pão e Rosas, 2010.

SAMPAIO Jr., P. A. Desenvolvimentismo e neodesenvolvimentismo: tragédia e farsa. In: Serviço Social e Sociedade. No 112, Cortez, 2012.

Capitalismo em crise: a natureza e dinâmica da crise econômica mundial. SP, ed. Instituto José Luis e Rosa Sudermann, 2009. 
Metástase da crise e aprofundamento da reversão neocolonial. In: Crítica a sociedade: revista de cultura política vl. 1 n. 3, Ed. Especial- Dossiê: A crise atual do capitalismo. Dez, 2011.

Os limites do melhoramento petista. Setembro, 2014. Disponível: http://marxismo21.org/wp-content/uploads/2014/09/P1\%C3\%ADnio-de-A-Sampaio-Jrdossie.pdf

SIQUEIRA, M. A política de assistência social do governo Lula: entre a inovação e a ortodoxia liberal. Dissertação de mestrado. Fevereiro, 2012.

SOARES, L.T. Os custos sociais do ajuste neoliberal na América Latina. SP, Cortez, 2009.

SOLER, A. A crise do Lulismo: ascensão e queda de um pacto social. 2015. Disponível em: http://marxismo21.org/wp-content/uploads/2013/06/A-crise-do-lulismo-A-Soler.pdf

VIANNA, M. O silencioso desmonte da seguridade social no Brasil. In: Política social e democracia. SP: Cortez, 2012.

\section{Sites:}

BANCO MUNDIAL:

http://wdi.worldbank.org

MDS:

www.mds.gov.br/

SIGA BRASIL:

www12.senado.gov.br/orcamento/sigabrasil 


\section{ANEXOS:}

I-

"Carta ao povo brasileiro

O Brasil quer mudar. Mudar para crescer, incluir, pacificar. Mudar para conquistar o desenvolvimento econômico que hoje não temos e a justiça social que tanto almejamos. Há em nosso país uma poderosa vontade popular de encerrar o atual ciclo econômico e político.

Se em algum momento, ao longo dos anos 90 , o atual modelo conseguiu despertar esperanças de progresso econômico e social, hoje a decepção com os seus resultados é enorme. Oito anos depois, o povo brasileiro faz o balanço e verifica que as promessas fundamentais foram descumpridas e as esperanças frustradas.

Nosso povo constata com pesar e indignação que a economia não cresceu e está muito mais vulnerável, a soberania do país ficou em grande parte comprometida, a corrupção continua alta e, principalmente, a crise social e a insegurança tornaram-se assustadoras.

O sentimento predominante em todas as classes e em todas as regiões é o de que o atual modelo esgotou-se. Por isso, o país não pode insistir nesse caminho, sob pena de ficar numa estagnação crônica ou até mesmo de sofrer, mais cedo ou mais tarde, um colapso econômico, social e moral.

O mais importante, no entanto, é que essa percepção aguda do fracasso do atual modelo não está conduzindo ao desânimo, ao negativismo, nem ao protesto destrutivo.

Ao contrário: apesar de todo o sofrimento injusto e desnecessário que é obrigada a suportar, a população está esperançosa, acredita nas possibilidades do país, mostra-se disposta a apoiar e a sustentar um projeto nacional alternativo, que faça o Brasil voltar a crescer, a gerar empregos, a reduzir a criminalidade, a resgatar nossa presença soberana e respeitada no mundo.

A sociedade está convencida de que o Brasil continua vulnerável e de que a verdadeira estabilidade precisa ser construída por meio de corajosas e cuidadosas mudanças que os responsáveis pelo atual modelo não querem absolutamente fazer.

A nítida preferência popular pelos candidatos de oposição que têm esse conteúdo de superação do impasse histórico nacional em que caímos, de correção dos rumos do país.

A crescente adesão à nossa candidatura assume cada vez mais o caráter de um movimento em defesa do Brasil, de nossos direitos e anseios fundamentais enquanto nação independente.

Lideranças populares, intelectuais, artistas e religiosos dos mais variados matizes ideológicos declaram espontaneamente seu apoio a um projeto de mudança do Brasil.

Prefeitos e parlamentares de partidos não coligados com o PT anunciam seu apoio. Parcelas significativas do empresariado vêm somar-se ao nosso projeto. Trata-se de uma vasta coalizão, em muitos aspectos suprapartidária, que busca abrir novos horizontes para o país.

O povo brasileiro quer mudar para valer. Recusa qualquer forma de continuísmo, seja ele assumido ou mascarado. Quer trilhar o caminho da redução de nossa vulnerabilidade externa pelo esforço conjugado de exportar mais e de criar um amplo mercado interno de consumo de massas. 
Quer abrir o caminho de combinar o incremento da atividade econômica com políticas sociais consistentes e criativas. O caminho das reformas estruturais que de fato democratizem e modernizem o país, tornando-o mais justo, eficiente e, ao mesmo tempo, mais competitivo no mercado internacional.

O caminho da reforma tributária, que desonere a produção. Da reforma agrária que assegure a paz no campo. Da redução de nossas carências energéticas e de nosso déficit habitacional. Da reforma previdenciária, da reforma trabalhista e de programas prioritários contra a fome e a insegurança pública.

O PT e seus parceiros têm plena consciência de que a superação do atual modelo, reclamada enfaticamente pela sociedade, não se fará num passe de mágica, de um dia par ao outro. Não há milagres na vida de um povo e de um país.

Será necessária uma lúcida e criteriosa transição entre o que temos hoje e aquilo que a sociedade reivindica. $\mathrm{O}$ que se desfez ou se deixou de fazer em oito anos não será compensado em oito dias.

O novo modelo não poderá ser produto de decisões unilaterais do governo, tal como ocorre hoje, nem será implementado por decreto, de modo voluntarista. Será fruto de uma ampla negociação nacional, que deve conduzir a uma autêntica aliança pelo país, a um novo contrato social, capaz de assegurar o crescimento com estabilidade.

Premissa dessa transição será naturalmente o respeito aos contratos e obrigações do país. As recentes turbulências do mercado financeiro devem ser compreendidas nesse contexto de fragilidade do atual modelo e de clamor popular pela sua superação.

À parte manobras puramente especulativas, que sem dúvida existem, o que há é uma forte preocupação do mercado financeiro com o mau desempenho da economia e com sua fragilidade atual, gerando temores relativos à capacidade de o país administrar sua dívida interna e externa. É o enorme endividamento público acumulado no governo Fernando Henrique Cardoso que preocupa os investidores.

Trata-se de uma crise de confiança na situação econômica do país, cuja responsabilidade primeira é do atual governo. Por mais que o governo insista, o nervosismo dos mercados e a especulação dos últimos dias não nascem das eleições.

Nascem, sim, da graves vulnerabilidades estruturais da economia apresentadas pelo governo, de modo totalitário, como o único caminho possível para o Brasil. Na verdade, há diversos países estáveis e competitivos no mundo que adotaram outras alternativas.

Não importa a quem a crise beneficia ou prejudica eleitoralmente, pois ela prejudica o Brasil. 0 que importa é que ela precisa ser evitada, pois causará sofrimento irreparável para a maioria da população. Para evitá-la, é preciso compreender que a margem de manobra da política econômica no curto prazo é pequena.

O Banco Central acumulou um conjunto de equívocos que trouxeram perdas às aplicações financeiras de inúmeras famílias. Investidores não especulativos, que precisam de horizontes claros, ficaram intranquilos. E os especuladores saíram à luz do dia, para pescar em águas turvas.

Que segurança o governo tem oferecido à sociedade brasileira? Tentou aproveitar-se da crise para ganhar alguns votos e, mais uma vez, desqualificar as oposições, num momento em que é necessário tranquilidade e compromisso com o Brasil. 
Como todos os brasileiros, quero a verdade completa. Acredito que o atual governo colocou o país novamente em um impasse. Lembrem-se todos: em 1998, o governo, para não admitir o fracasso do seu populismo cambial, escondeu uma informação decisiva. A de que o real estava artificialmente valorizado e de que o país estava sujeito a um ataque especulativo de proporções inéditas.

Estamos de novo atravessando um cenário semelhante. Substituímos o populismo cambial pela vulnerabilidade da âncora fiscal. O caminho para superar a fragilidade das finanças públicas é aumentar e melhorar a qualidade das exportações e promover uma substituição competitiva de importações no curto prazo.

Aqui ganha toda a sua dimensão de uma política dirigida a valorizar o agronegócio e a agricultura familiar. A reforma tributária, a política alfandegária, os investimentos em infra-estrutura e as fontes de financiamento públicas devem ser canalizadas com absoluta prioridade para gerar divisas.

Nossa política externa deve ser reorientada para esse imenso desafio de promover nossos interesses comerciais e remover graves obstáculos impostos pelos países mais ricos às nações em desenvolvimento.

Estamos conscientes da gravidade da crise econômica. Para resolvê-la, o PT está disposto a dialogar com todos os segmentos da sociedade e com o próprio governo, de modo a evitar que a crise se agrave e traga mais aflição ao povo brasileiro.

Superando a nossa vulnerabilidade externa, poderemos reduzir de forma sustentada a taxa de juros. Poderemos recuperar a capacidade de investimento público tão importante para alavancar o crescimento econômico.

Esse é o melhor caminho para que os contratos sejam honrados e o país recupere a liberdade de sua política econômica orientada para o desenvolvimento sustentável.

Ninguém precisa me ensinar a importância do controle da inflação. Iniciei minha vida sindical indignado com o processo de corrosão do poder de comprar dos salários dos trabalhadores.

Quero agora reafirmar esse compromisso histórico com o combate à inflação, mas acompanhado do crescimento, da geração de empregos e da distribuição de renda, construindo um Brasil mais solidário e fraterno, um Brasil de todos.

A volta do crescimento é o único remédio para impedir que se perpetue um círculo vicioso entre metas de inflação baixas, juro alto, oscilação cambial brusca e aumento da dívida pública.

O atual governo estabeleceu um equilíbrio fiscal precário no país, criando dificuldades para a retomada do crescimento. Com a política de sobrevalorização artificial de nossa moeda no primeiro mandato e com a ausência de políticas industriais de estímulo à capacidade produtiva, o governo não trabalhou como podia para aumentar a competitividade da economia.

Exemplo maior foi o fracasso na construção e aprovação de uma reforma tributária que banisse o caráter regressivo e cumulativo dos impostos, fardo insuportável para o setor produtivo e para a exportação brasileira.

A questão de fundo é que, para nós, o equilíbrio fiscal não é um fim, mas um meio. Queremos equilíbrio fiscal para crescer e não apenas para prestar contas aos nossos credores. 
Vamos preservar o superávit primário o quanto for necessário para impedir que a dívida interna aumente e destrua a confiança na capacidade do governo de honrar os seus compromissos.

Mas é preciso insistir: só a volta do crescimento pode levar o país a contar com um equilíbrio fiscal consistente e duradouro. A estabilidade, o controle das contas públicas e da inflação são hoje um patrimônio de todos os brasileiros. Não são um bem exclusivo do atual governo, pois foram obtidos com uma grande carga de sacrifícios, especialmente dos mais necessitados.

O desenvolvimento de nosso imenso mercado pode revitalizar e impulsionar o conjunto da economia, ampliando de forma decisiva o espaço da pequena e da microempresa, oferecendo ainda bases sólidas par ampliar as exportações.

Para esse fim, é fundamentar a criação de uma Secretaria Extraordinária de Comércio Exterior, diretamente vinculada à Presidência da República.

Há outro caminho possível. É o caminho do crescimento econômico com estabilidade e responsabilidade social. As mudanças que forem necessárias serão feitas democraticamente, dentro dos marcos institucionais.

Vamos ordenar as contas públicas e mantê-las sob controle. Mas, acima de tudo, vamos fazer um compromisso pela produção, pelo emprego e por justiça social.

O que nos move é a certeza de que o Brasil é bem maior que todas as crises. O país não suporta mais conviver com a idéia de uma terceira década perdidas.

O Brasil precisa navegar no mar aberto do desenvolvimento econômico e social. É com essa conviç̧ão que chamo todos os que querem o bem do Brasil a se unirem em torno de um programa de mudanças corajosas e responsáveis.

Luiz Inácio Lula da Silva

São Paulo, 22 de junho de 2002" 
ANEXO II

\begin{tabular}{|c|c|c|}
\hline \multicolumn{3}{|l|}{ Governo Lula 10 Mandato } \\
\hline Pasta & Ministro & Partido \\
\hline Agricultura & Roberto Rodrigues & $\begin{array}{l}\text { s/ } \\
\text { partido }\end{array}$ \\
\hline Assistência Social & Benedita da Silva & PT \\
\hline Casa Civil & José Dirceu & PT \\
\hline Ciência e Tecnologia & Roberto Amaral & PSB \\
\hline Comunicações & Miro Teixeira & PDT \\
\hline Cultura & Gilberto Gil & $\begin{array}{l}\text { s/ } \\
\text { partido }\end{array}$ \\
\hline Defesa & Jorge Viegas Filho & $\begin{array}{l}\text { s/ } \\
\text { partido }\end{array}$ \\
\hline Desenvolvimento Industria e Comércio Exterior & Luiz Fernando Furlan & $\begin{array}{l}\text { s/ } \\
\text { partido }\end{array}$ \\
\hline Desenvolvimento Agrário & Miguel Rosseto & PT \\
\hline Educação & Cristovam Buarque & PDT \\
\hline Esporte & Agnelo Queiroz & PC do B \\
\hline Fazenda & Antonio Palocci & PT \\
\hline Integração Nacional & Ciro Gomes & PPS \\
\hline Justiça & Márcio Thomaz Bastos & $\begin{array}{l}\text { s/ } \\
\text { partido }\end{array}$ \\
\hline Meio Ambiente & Marina Silva & PT \\
\hline Minas e Energia & Dilma Roussef & PT \\
\hline Cidades & Olívio Dutra & PT \\
\hline Planejamento Orçamento e Gestão & Guido Mantega & PT \\
\hline Previdência & Ricardo Berzoini & PT \\
\hline Saúde & Humberto Costa & PT \\
\hline Segurança Alimentar & José Graziano Filho & $\begin{array}{l}\text { s/ } \\
\text { partido }\end{array}$ \\
\hline Relações Exteriores & Celso Amorim & $\begin{array}{l}\text { s/ } \\
\text { partido }\end{array}$ \\
\hline Trabalho e Emprego & Jaques Wagner & PT \\
\hline Transportes & Anderson Adauto & $\mathrm{PL}$ \\
\hline Turismo & Walfrido Mares Guia & PTB \\
\hline Secretaria-Geral da Presidência & Luiz Dulci & PT \\
\hline Secretaria de Comunicação & Luiz Gushiken & PT \\
\hline Secretaria de Desenvolvimento Econômico e Social & Tarso Genro & PT \\
\hline Secretaria de Direitos da Mulher & Emilia Fernandes & PT \\
\hline Secretaria de Estado dos Direitos Humanos & Nilmário Miranda & PT \\
\hline Secretaria de Imprensa e Divulgação da Presidência & Ricardo Kotscho & $\begin{array}{l}\text { s/ } \\
\text { partido }\end{array}$ \\
\hline Corregedoria-Geral da União & Waldir Pires & PT \\
\hline Advocacia Geral da União & Álvaro Ribeiro da Costa & $\begin{array}{l}\text { s/ } \\
\text { partido }\end{array}$ \\
\hline
\end{tabular}




\begin{tabular}{|l|l|l|}
\hline Porta-Voz & André Singer & $\begin{array}{l}\text { s/ } \\
\text { partido }\end{array}$ \\
\hline Gabinete de Segurança Institucional & Jorge Armando Félix & $\begin{array}{l}\text { s/ } \\
\text { partido }\end{array}$ \\
\hline Banco Central & Henrique Meirelles & PSDB \\
\hline
\end{tabular}

\begin{tabular}{|c|c|c|}
\hline \multicolumn{3}{|l|}{ Governo Lula 20 Mandato } \\
\hline Pasta & Ministro & Partido \\
\hline Agricultura & Luis Carlos Guedes Pinto & $\begin{array}{l}\mathrm{s} / \\
\text { partido }\end{array}$ \\
\hline Agricultura & Reinhold Stephanes & PMDB \\
\hline Agricultura & Wagner Rossi & PMDB \\
\hline Assuntos Estratégicos do Brasil & Roberto Mangabeira Unger & PMDB \\
\hline Assuntos Estratégicos do Brasil & $\begin{array}{l}\text { Samuel Pinheiro Guimarães } \\
\text { Net }\end{array}$ & $\begin{array}{l}\mathrm{s} / \\
\text { partido }\end{array}$ \\
\hline Casa Civil & Dilma Roussef & PT \\
\hline Casa Civil & Erenice Guerra & $\begin{array}{l}\mathrm{s} / \\
\text { partido }\end{array}$ \\
\hline Ciência e Tecnologia & Sergio Machado Rezende & PSB \\
\hline Comunicação Social & Franklin Martins & s/ \\
\hline Comunicações & Hélio Costa & PMDB \\
\hline Comunicações & José Artur Filardi & PMDB \\
\hline Cultura & Juca Ferreira & PT \\
\hline Defesa & Waldir Pires & PT \\
\hline Defesa & Nelson Jobim & PMDB \\
\hline Desenvolvimento Industria e Comércio Exterior & Miguel Jorge & $\begin{array}{l}\mathrm{s} / \\
\text { partido }\end{array}$ \\
\hline Desenvolvimento Agrário & Guilherme Cassel & PT \\
\hline Educação & Fernando Haddad & PT \\
\hline Esporte & Orlando Silva & PCdoB \\
\hline Fazenda & Guido Mantega & $\begin{array}{l}\mathrm{s} / \\
\text { partido }\end{array}$ \\
\hline Integração Nacional & Pedro Brito & PSB \\
\hline Integração Nacional & Geddel Vieira Lima & PMDB \\
\hline Justiça & Tarso Genro & PT \\
\hline Meio Ambiente & Carlos Minc & PT \\
\hline Minas e Energia & Edson Lobão & PMDB \\
\hline Cidades & Olívio Dutra & PT \\
\hline Planejamento Orçamento e Gestão & Paulo Bernardo & PT \\
\hline Previdência & José Barroso Pimentel & PT \\
\hline Saúde & José Gomes Temporão & s/ \\
\hline Desenvolvimento Social e Combate a Fome & Patrus Ananias & PT \\
\hline Relações Exteriores & Celso Amorim & PT \\
\hline
\end{tabular}




\begin{tabular}{|l|l|l|}
\hline Trabalho e Emprego & Carlos Lupi & PDT \\
\hline Transportes & Alfredo Nascimento & PR \\
\hline Turismo & Luiz Barretto Filho & PT \\
\hline $\begin{array}{l}\text { Secretaria de Políticas de Promoção da Igualdade } \\
\text { Racial }\end{array}$ & Matilde Ribeiro & PT \\
\hline $\begin{array}{l}\text { Secretaria de Políticas de Promoção da Igualdade } \\
\text { Racial }\end{array}$ & Édson Santos & PT \\
\hline $\begin{array}{l}\text { Secretaria de Políticas de Promoção da Igualdade } \\
\text { Racial }\end{array}$ & Eloi Ferreira Araújo & PT \\
\hline Secretaria Especial de Políticas para as Mulheres & Nilcéia Freire & $\begin{array}{l}\text { s/ } \\
\text { partido }\end{array}$ \\
\hline Secretaria de Estado dos Direitos Humanos & Paulo Vannuchi & $\begin{array}{l}\text { s/ } \\
\text { partido }\end{array}$ \\
\hline Controladoria-Geral da União & Jorge Hage & $\begin{array}{l}\text { s/ } \\
\text { partido }\end{array}$ \\
\hline Advocacia Geral da União & José Dias Toffoli & $\begin{array}{l}\text { s/ } \\
\text { partido }\end{array}$ \\
\hline Gabinete de Segurança Institucional & $\begin{array}{l}\text { General Jorge Armando } \\
\text { Félix }\end{array}$ & $\begin{array}{l}\text { s/ } \\
\text { partido }\end{array}$ \\
\hline Banco Central & Henrique Meirelles & PMDB \\
\hline
\end{tabular}


ANEXO III

Seguridade Social

Dotação Inicial LOA 2014

Execução Orçamentária da LOA 2014

\begin{tabular}{lrrrrrr} 
& Dotação Inicial & Autorizado & Empenhado & $\begin{array}{c}\text { Liquidado } \\
\text { (Subelemento) }\end{array}$ & Pago & RP Pago \\
\cline { 2 - 7 } Assistência Social & 68.216 .343 .528 & 70.938 .059 .410 & 70.433 .458 .816 & 68.338 .786 .752 & 66.847 .735 .368 & 2.892 .320 .553 \\
\cline { 2 - 6 } Previdência Social & 473.509 .193 .503 & 495.629 .715 .261 & 495.305 .597 .961 & 494.021 .483 .210 & 471.639 .642 .773 & 15.965 .216 .831 \\
Saúde & 98.036 .362 .031 & 100.313 .538 .371 & 94.065 .346 .001 & 86.657 .737 .261 & 86.327 .540 .676 & 7.518 .600 .407 \\
\cline { 2 - 6 } & & & & & &
\end{tabular}

Dotação Inicial Composição

Assistência Social

68.216.343.528 $\quad 11 \%$

Previdência Social

473.509.193.503 74\%

Saúde

\begin{tabular}{rr}
\hline $\mathbf{4 7 3 . 5 0 9 . 1 9 3 . 5 0 3}$ & $\mathbf{7 4 \%}$ \\
\hline 98.036 .362 .031 & $15 \%$ \\
\hline 639.761 .899 .062 & $100 \%$
\end{tabular}


Assistência Social

Dotação Inicial LOA 2014

\begin{tabular}{|l|r|r|r|r|r|r|r|}
\hline & Composição & Dotação Inicial & Autorizado & Empenhado & $\begin{array}{c}\text { Liquidado } \\
\text { (Subelemento) }\end{array}$ & \multicolumn{1}{c|}{ Pago } \\
\hline Assistência Social & $\mathbf{1 0 0 \%}$ & $\mathbf{6 8 . 2 1 6 . 3 4 3 . 5 2 8}$ & $\mathbf{7 0 . 9 3 8 . 0 5 9 . 4 1 0}$ & $\mathbf{7 0 . 4 3 3 . 4 5 8 . 8 1 6}$ & $\mathbf{6 8 . 3 3 8 . 7 8 6 . 7 5 2}$ & $\mathbf{6 6 . 8 4 7 . 7 3 5 . 3 6 8}$ & $\mathbf{2 . 8 9 2 . 3 2 0 . 5 5 3}$ \\
\hline BPC & $51 \%$ & 34.653 .625 .524 & 35.942 .390 .438 & 35.941 .879 .631 & 35.863 .303 .325 & 34.562 .598 .611 & 1.468 .459 .848 \\
\hline Bolsa Família & $36 \%$ & 24.650 .890 .000 & 26.155 .890 .000 & 26.155 .890 .000 & 26.125 .678 .118 & 26.125 .678 .118 & 0 \\
\hline Outros & $13 \%$ & 8.911 .828 .004 & 8.839 .778 .972 & 8.335 .689 .185 & 6.349 .805 .309 & 6.159 .458 .639 & 1.423 .860 .706 \\
\hline
\end{tabular}

Evolução Bruta OGU

Dotação Inicial LOAs 2003 a 2014

\begin{tabular}{|l|r|r|r|r|}
\hline Função / Ano & $\mathbf{2 0 0 3}$ & $\mathbf{2 0 0 4}$ & $\mathbf{2 0 0 5}$ & $\mathbf{2 0 0 6}$ \\
\hline Assistência Social & $\mathrm{R} \$ 8.716 .535 .811,00$ & $\mathrm{R} \$ 13.171 .487 .485,00$ & $\mathrm{R} \$ 15.961 .400 .416,00$ & $\mathrm{R} \$ 21.282 .618 .149,00$ \\
\hline Previdência Social & $\mathrm{R} \$ 131.841 .404 .768,00$ & $\mathrm{R} \$ 160.707 .742 .715,00$ & $\mathrm{R} \$ 180.307 .473 .922,00$ & $\mathrm{R} \$ 202.455 .072 .353,00$ \\
\hline Saúde & $\mathrm{R} \$ 27.782 .999 .932,00$ & $\mathrm{R} \$ 33.099 .623 .569,00$ & $\mathrm{R} \$ 36.684 .557 .843,00$ & $\mathrm{R} \$ 40.497 .699 .395,00$ \\
\hline Total & $\mathrm{R} \$ 168.340 .940 .511,00$ & $\mathrm{R} \$ 206.978 .853 .769,00$ & $\mathrm{R} \$ 232.953 .432 .181,00$ & $\mathrm{R} \$ 264.235 .389 .897,00$ \\
\hline
\end{tabular}




\begin{tabular}{|l|r|r|r|r|}
\hline Função / Ano & 2007 & 2008 & 2009 & 2010 \\
\hline Assistência Social & $\mathrm{R} \$ 24.316 .846 .734,00$ & $\mathrm{R} \$ 28.595 .109 .595,00$ & $\mathrm{R} \$ 32.683 .705 .705,00$ & $\mathrm{R} \$ 38.629 .489 .810,00$ \\
\hline Previdência Social & $\mathrm{R} \$ 233.078 .618 .114,00$ & $\mathrm{R} \$ 252.744 .591 .152,00$ & $\mathrm{R} \$ 293.030 .008 .349,00$ & $\mathrm{R} \$ 313.168 .686 .731,00$ \\
\hline Saúde & $\mathrm{R} \$ 45.665 .189 .468,00$ & $\mathrm{R} \$ 48.499 .012 .638,00$ & $\mathrm{R} \$ 54.739 .903 .044,00$ & $\mathrm{R} \$ 61.616 .920 .571,00$ \\
\hline Total & $\mathrm{R} \$ 303.060 .654 .316,00$ & $\mathrm{R} \$ 329.838 .713 .385,00$ & $\mathrm{R} \$ 380.453 .617 .098,00$ & $\mathrm{R} \$ 413.415 .097 .112,00$ \\
\hline
\end{tabular}

\begin{tabular}{|l|r|r|r|r|}
\hline & 2011 & 2012 & 2013 & 2014 \\
\hline Assistência Social & $\mathrm{R} \$ 41.701 .222 .373,00$ & $\mathrm{R} \$ 54.761 .062 .266,00$ & $\mathrm{R} \$ 61.777 .273 .509,00$ & $\mathrm{R} \$ 68.216 .343 .528,00$ \\
\hline Previdência Social & $\mathrm{R} \$ 351.177 .355 .423,00$ & $\mathrm{R} \$ 391.762 .225 .809,00$ & $\mathrm{R} \$ 429.532 .519 .508,00$ & $\mathrm{R} \$ 473.509 .193 .503,00$ \\
\hline Saúde & $\mathrm{R} \$ 71.368 .228 .613,00$ & $\mathrm{R} \$ 85.429 .797 .081,00$ & $\mathrm{R} \$ 92.296 .122 .428,00$ & $\mathrm{R} \$ 98.036 .362 .031,00$ \\
\hline Total & $\mathrm{R} \$ 464.246 .806 .409,00$ & $\mathrm{R} \$ 531.953 .085 .156,00$ & $\mathrm{R} \$ 583.605 .915 .445,00$ & $\mathrm{R} \$ 639.761 .899 .062,00$ \\
\hline
\end{tabular}

Evolução \% OGU

Dotação Inicial LOAs 2003 a 2014

\begin{tabular}{|l|r|r|r|r|r|r|r|r|r|r|r|r|}
\hline Função / Ano & $\mathbf{2 0 0 3}$ & $\mathbf{2 0 0 4}$ & $\mathbf{2 0 0 5}$ & $\mathbf{2 0 0 6}$ & $\mathbf{2 0 0 7}$ & $\mathbf{2 0 0 8}$ & $\mathbf{2 0 0 9}$ & $\mathbf{2 0 1 0}$ & $\mathbf{2 0 1 1}$ & $\mathbf{2 0 1 2}$ & $\mathbf{2 0 1 3}$ & $\mathbf{2 0 1 4}$ \\
\hline Assistência Social & $5 \%$ & $6 \%$ & $7 \%$ & $8 \%$ & $8 \%$ & $9 \%$ & $9 \%$ & $9 \%$ & $9 \%$ & $10 \%$ & $11 \%$ & $11 \%$ \\
\hline Previdência Social & $78 \%$ & $78 \%$ & $77 \%$ & $77 \%$ & $77 \%$ & $77 \%$ & $77 \%$ & $76 \%$ & $76 \%$ & $74 \%$ & $74 \%$ & $74 \%$ \\
\hline Saúde & $17 \%$ & $16 \%$ & $16 \%$ & $15 \%$ & $15 \%$ & $15 \%$ & $14 \%$ & $15 \%$ & $15 \%$ & $16 \%$ & $16 \%$ & $15 \%$ \\
\hline
\end{tabular}


ANEXO IV

Tabela. Indicadores Globais de Desenvolvimento: Índice de Gini de 149 nações segundo Banco Mundial (http://wdi.worldbank.org/table/2.9\#).

\begin{tabular}{|c|c|c|c|c|c|c|c|}
\hline$\#$ & País & Ano & Índice de Gini & $\#$ & País & Ano & Índice de Gini \\
\hline 1 & Ukraine & 2010 & 24.8 & 38 & Poland & 2011 & 32.8 \\
\hline 2 & Slovenia & 2011 & 24.9 & 39 & Azerbaijan & 2008 & 33.0 \\
\hline 3 & Sweden & 2005 & 26.1 & 40 & $\begin{array}{l}\text { Bosnia and } \\
\text { Herzegovina }\end{array}$ & 2007 & 33.0 \\
\hline 4 & Iceland & 2010 & 26.3 & 41 & Mali & 2010 & 33.0 \\
\hline 5 & Czech Republic & 2011 & 26.4 & 42 & Belgium & 2000 & 33.1 \\
\hline 6 & Belarus & 2011 & 26.5 & 43 & Burundi & 2006 & 33.3 \\
\hline 7 & Slovak Republic & 2011 & 26.6 & 44 & Kyrgyz Republic & 2011 & 33.4 \\
\hline 8 & Norway & 2010 & 26.8 & 45 & Croatia & 2008 & 33.6 \\
\hline 9 & Denmark & 2010 & 26.9 & 46 & Ethiopia & 2010 & 33.6 \\
\hline 10 & Romania & 2012 & 27.3 & 47 & India & 2011 & 33.6 \\
\hline 11 & Afghanistan & 2007 & 27.8 & 48 & Canada & 2010 & 33.7 \\
\hline 12 & Finland & 2010 & 27.8 & 49 & Guinea & 2012 & 33.7 \\
\hline 13 & Kazakhstan & 2010 & 28.6 & 50 & Jordan & 2010 & 33.7 \\
\hline 14 & Hungary & 2011 & 28.9 & 51 & $\begin{array}{l}\text { Sao Tome and } \\
\text { Principe }\end{array}$ & 2010 & 33.9 \\
\hline 15 & Netherlands & 2010 & 28.9 & 52 & Australia & 2003 & 34.0 \\
\hline 16 & Albania & 2012 & 29.0 & 53 & Bulgaria & 2011 & 34.3 \\
\hline 17 & Iraq & 2012 & 29.5 & 54 & $\begin{array}{l}\text { West Bank and } \\
\text { Gaza }\end{array}$ & 2009 & 34.5 \\
\hline 18 & Pakistan & 2010 & 29.6 & 55 & Greece & 2010 & 34.7 \\
\hline 19 & Serbia & 2010 & 29.7 & 56 & Uzbekistan & 2003 & 35.2 \\
\hline 20 & Austria & 2004 & 30.0 & 57 & Algeria & 1995 & 35.3 \\
\hline 21 & Armenia & 2012 & 30.3 & 58 & Sudan & 2009 & 35.3 \\
\hline 22 & Timor-Leste & 2007 & 30.4 & 59 & Sierra Leone & 2011 & 35.4 \\
\hline 23 & Germany & 2010 & 30.6 & 60 & Guinea-Bissau & 2002 & 35.5 \\
\hline 24 & Moldova & 2011 & 30.6 & 61 & Italy & 2010 & 35.5 \\
\hline 25 & Montenegro & 2011 & 30.6 & 62 & Vietnam & 2012 & 35.6 \\
\hline 26 & Egypt, Arab Rep. & 2008 & 30.8 & 63 & Spain & 2010 & 35.8 \\
\hline 27 & Tajikistan & 2009 & 30.8 & 64 & $\begin{array}{l}\text { Syrian Arab } \\
\text { Republic }\end{array}$ & 2004 & 35.8 \\
\hline 28 & Niger & 2011 & 31.2 & 65 & Tunisia & 2010 & 35.8 \\
\hline 29 & France & 2005 & 31.7 & 66 & Mauritius & 2012 & 35.9 \\
\hline 30 & Cambodia & 2011 & 31.8 & 67 & Yemen, Rep. & 2005 & 35.9 \\
\hline 31 & Bangladesh & 2010 & 32.1 & 68 & Latvia & 2011 & 36.0 \\
\hline 32 & Ireland & 2010 & 32.1 & 69 & Lao PDR & 2012 & 36.2 \\
\hline 33 & Japan & 2008 & 32.1 & 70 & Sri Lanka & 2009 & 36.4 \\
\hline 34 & Switzerland & 2004 & 32.4 & 71 & Mongolia & 2007 & 36.5 \\
\hline 35 & Lithuania & 2011 & 32.6 & 72 & China & 2011 & 37.0 \\
\hline 36 & Estonia & 2011 & 32.7 & 73 & Maldives & 2004 & 37.4 \\
\hline 37 & Nepal & 2010 & 32.8 & 74 & Tanzania & 2012 & 37.8 \\
\hline
\end{tabular}




\begin{tabular}{|c|c|c|c|c|c|c|c|}
\hline$\#$ & País & Ano & Índice de Gini & $\#$ & País & Ano & Índice de Gin \\
\hline 75 & United Kingdom & 2010 & 38.0 & 112 & Uganda & 2012 & 44.6 \\
\hline 76 & Indonesia & 2011 & 38.1 & 113 & Venezuela, RB & 2006 & 44.8 \\
\hline 77 & Liberia & 2007 & 38.2 & 114 & Peru & 2012 & 45.3 \\
\hline 78 & Iran, Islamic Rep. & 2005 & 38.3 & 115 & Jamaica & 2004 & 45.5 \\
\hline 79 & Bhutan & 2012 & 38.7 & 116 & $\begin{array}{l}\text { Dominican } \\
\text { Republic }\end{array}$ & 2012 & 45.7 \\
\hline 80 & Thailand & 2010 & 39.4 & 117 & Mozambique & 2009 & 45.7 \\
\hline 81 & $\begin{array}{l}\text { Russian } \\
\text { Federation }\end{array}$ & 2009 & 39.7 & 118 & Nicaragua & 2009 & 45.7 \\
\hline 82 & Burkina Faso & 2009 & 39.8 & 119 & Togo & 2011 & 46.0 \\
\hline 83 & Djibouti & 2002 & 40.0 & 120 & Malawi & 2010 & 46.2 \\
\hline 84 & Turkey & 2011 & 40.0 & 121 & Malaysia & 2009 & 46.2 \\
\hline 85 & Congo, Rep. & 2011 & 40.2 & 122 & Bolivia & 2012 & 46.6 \\
\hline 86 & Senegal & 2011 & 40.3 & 123 & Ecuador & 2012 & 46.6 \\
\hline 87 & Mauritania & 2008 & 40.5 & 124 & Gambia, The & 2003 & 47.3 \\
\hline 88 & Madagascar & 2010 & 40.6 & 125 & Kenya & 2005 & 47.7 \\
\hline 89 & Cameroon & 2007 & 40.7 & 126 & Paraguay & 2012 & 48.0 \\
\hline 90 & Turkmenistan & 1998 & 40.8 & 127 & Mexico & 2012 & 48.1 \\
\hline 91 & Morocco & 2007 & 40.9 & 128 & Costa Rica & 2012 & 48.6 \\
\hline 92 & United States & 2010 & 41.1 & 129 & Chile & 2011 & 50.8 \\
\hline 93 & Uruguay & 2012 & 41.3 & 130 & Rwanda & 2011 & 50.8 \\
\hline 94 & Georgia & 2012 & 41.4 & 131 & $\begin{array}{l}\text { Papua New } \\
\text { Guinea }\end{array}$ & 1996 & 50.9 \\
\hline 95 & El Salvador & 2012 & 41.8 & 132 & Swaziland & 2009 & 51.5 \\
\hline 96 & Gabon & 2005 & 42.2 & 133 & Panama & 2012 & 51.9 \\
\hline 97 & St. Lucia & 1995 & 42.6 & 134 & Guatemala & 2011 & 52.4 \\
\hline 98 & Angola & 2008 & 42.7 & 135 & Brazil & 2012 & 52.7 \\
\hline 99 & Fiji & 2008 & 42.8 & 136 & Suriname & 1999 & 52.9 \\
\hline 100 & Ghana & 2005 & 42.8 & 137 & Belize & 1999 & 53.1 \\
\hline 101 & Israel & 2010 & 42.8 & 138 & Colombia & 2012 & 53.5 \\
\hline 102 & Nigeria & 2010 & 43.0 & 139 & Lesotho & 2010 & 54.2 \\
\hline 103 & Philippines & 2012 & 43.0 & 140 & $\begin{array}{l}\text { Central African } \\
\text { Republic }\end{array}$ & 2008 & 56.3 \\
\hline 104 & Cote d'Ivoire & 2008 & 43.2 & 141 & Honduras & 2011 & 57.4 \\
\hline 105 & Chad & 2011 & 43.3 & 142 & Zambia & 2010 & 57.5 \\
\hline 106 & Benin & 2011 & 43.5 & 143 & Haiti & 2001 & 59.2 \\
\hline 107 & Argentina & 2011 & 43.6 & 144 & Botswana & 2009 & 60.5 \\
\hline 108 & Cabo Verde & 2007 & 43.8 & 145 & $\begin{array}{l}\text { Micronesia, Fed. } \\
\text { Sts. }\end{array}$ & 2000 & 61.1 \\
\hline 109 & Macedonia, FYR & 2008 & 44.2 & 146 & Namibia & 2009 & 61.3 \\
\hline 110 & Congo, Dem. Rep. & 2005 & 44.4 & 147 & Comoros & 2004 & 64.3 \\
\hline \multirow[t]{2}{*}{111} & Guyana & 1998 & 44.5 & 148 & South Africa & 2011 & 65.0 \\
\hline & & & & 149 & Seychelles & 2006 & 65.8 \\
\hline
\end{tabular}

